\title{
Natural Products from Marine Invertebrates and Microorganisms in Brazil between 2004 and 2017: Still the Challenges, More Rewards
}

\author{
Laura P. Ióca, Karen J. Nicacio and Roberto G. S. Berlinck* \\ Instituto de Química de São Carlos, Universidade de São Paulo, CP 780, \\ 13560-970 São Carlos-SP, Brazil
}

\begin{abstract}
The Brazilian marine biodiversity represents a unique, yet underexplored resource of biologically active compounds. This review provides an analysis of the development of marine natural products chemistry in Brazil within the period comprised between 2004 and 2017. Emphasis is directed towards marine invertebrate and marine microorganisms metabolites, including isolation, structure analysis, biosynthesis, bioactivities and total synthesis. An overview of the research on marine natural products by Brazilian researchers is also discussed, as well as perspectives for the development of the chemistry of marine natural products in Brazil.
\end{abstract}

Keywords: marine natural products, marine sponges, marine bacteria, marine fungi, marine alkaloids, marine polyketides

\section{Introduction}

The chemistry of natural products is a science well established in Brazil, spanned over 60 years and all over the country. Most of Brazilian natural product researchers devote efforts to the investigation of plant metabolites. From the beginning of the $21^{\text {st }}$ century there has been a substantial growth of research on microbial natural products by Brazilian researchers, ${ }^{1}$ and on marine natural products as well. The interest of Brazilian natural product chemists to investigate other sources than plants for the isolation of secondary metabolites are consequential to the chemical diversity of marine and microbial organisms. Clearly distinctive biosynthetic pathways arose from unrelated biological groups or from their respective associated microorganisms. Increasing evidences demonstrate that bacteria, cyanobacteria and fungi are now considered as the actual producers of many natural products first isolated from macroorganisms, both terrestrial ${ }^{2,3}$ and marine. ${ }^{4}$

While the knowledge on the secondary metabolism interplay between micro- and macroorganisms is only starting to be deciphered, it seems clear that the approximate number of 300,000 secondary metabolites so far identified from all biological sources may represent only a tiny fraction of genes regulating the biosynthesis

*e-mail: rgsberlinck@iqsc.usp.br

This paper is part of the PubliSBQ Special Issue "IUPAC-2017" (http://publi.sbq.org.br/). of natural products. ${ }^{5}$ Unexpressed genes coding the biosynthesis of natural products appear to be the largest fraction of genomes encoding the biochemistry of natural products pathways. Thus, if the sciences of investigating natural products have expanded to unexpected boundaries in a very impressive rate since the advent of genomic tools, there is no need to say that much more remains to be done, particularly exploring new biological sources for the discovery of secondary metabolites. Among poorly known sources of natural products, Gram-negative bacteria are now under a more intense scrutiny, since these bacteria are capable of survive in many habitats and produce a series of antimicrobial molecules. ${ }^{6}$ Additionally, the exciting discovery of a new marine biome at the mouth of the Amazon river provided a series of yet uninvestigated species of marine sponges and other marine invertebrates. ${ }^{7}$

The move of natural products chemistry in Brazil towards contemporary approaches to discover novel natural products has been slow, for various reasons. First, the lack of expertise on the use of genomic tools for the investigation of secondary metabolism is critical. This is a severe gap that must be faced in the current education of graduate students involved in natural products chemistry projects. Second, the need of closer collaborative efforts between chemists, pharmacologists and biologists, including microbiologists, is evident. There are still very few collaborative research efforts in Brazil involving bioassay-guided isolation, as well as the chemical synthesis and medicinal chemistry of 
bioactive or chemically unique natural products. However, the most difficult challenge to address is the need to develop a truly innovative natural products science in Brazil. A new vision in the way of natural product chemistry has been performed is very much in need of consideration, since the country is still one with the highest biodiversity in the planet-remaining largely unexplored towards the identification of novel, biologically active natural products. ${ }^{8}$

The Brazilian marine environment is now under a more intense investigation by Brazilian natural product chemists, as shown by the exponential growth of research in this field. This review covers the literature on natural products chemistry of marine invertebrates and marine microorganisms published between 2004 and August 2017 by Brazilian researchers as corresponding authors. Research on algae natural products in Brazil has been the subject of two special issues of the Brazilian Journal of Pharmacognosy, ${ }^{9}$ and therefore will not be herein discussed. A special issue of the same journal on marine natural products has been published in $2015 .{ }^{10}$ Publications dealing with crude extracts or with only partially identified, bioactive or not, chemical entities or even primary metabolites, are not included as well.

\section{Marine Microorganisms}

As predicted in a previous review, ${ }^{11}$ the investigation of marine-derived fungi and bacteria metabolites by Brazilian researchers has grown impressively during over the last decade. Collaborative efforts between microbiologists and chemists led to the discovery of a number of bioactive metabolites produced by marine-derived microbes. Investigation on the biosynthesis of marine-derived microbial metabolites during this period is also noteworthy. The large majority of bacteria metabolites isolated by Brazilian researchers are derived from amino acids, while polyketides corresponds to up $50 \%$ for fungi secondary metabolites.

\subsection{Bacteria}

A sponge-associated strain of Pseudomonas fluorescens produced the known diketopiperazine cyclo-( $L$-Leu- $L$-Pro) (1, Figure 1). ${ }^{12}$ Assignment of the absolute configuration was based on comparison with literature data, with no mention to a value of specific rotation. Cultures of Streptomyces sp. provided the known diketopiperazines (Figure 1) cyclo-( $L$-Phe-trans-4-OH-L-Pro) (2), cyclo( $L$-Phe- $L$-Pro) (3) and cyclo-( $L$-Trp- $L$-Pro) (4). No mention to the experimental assignment of absolute configuration was provided. ${ }^{13}$ Well-known prodigiosin (5), deoxycholic acid (6) and cholic acid (7) were isolated from cultures of Pseudoalteromonas sp. (Figure 1). ${ }^{14}$ Since the production of sterols by bacteria is very unlikely, ${ }^{15}$ growth media used in this investigation, namely starch casein agar, may contain sterols, thus compounds $\mathbf{6}$ and $\mathbf{7}$ may be media components.

The new 2(1H)-pyrazinones giovaninones A-D (8-11, Figure 1) were produced by a strain of Streptomyces sp. isolated from marine sediments. ${ }^{16}$ Compounds were identified by analysis of spectroscopic data, using HPLC-SPE-NMR (high performance liquid chromatography-solid phase extraction-nuclear magnetic resonance) with a cryoprobe. No bioactivity data was reported for compounds 8-11.

Bromotyrosine-derived verongidoic acid (12), 11-hydroxyaerothionin (13) and fistularin-3 (14) have been isolated from cultures of Pseudovibrio denitrificans<smiles>CC(C)C[C@@H]1NC(=O)[C@@H]2CCCN2C1=O</smiles><smiles>[R]C1C[C@H]2C(=O)N[C@H](Cc3ccccc3)C(=O)N2C1</smiles><smiles>O=C1N[C@H](Cc2c[nH]c3ccccc23)C(=O)N2CCC[C@H]12</smiles><smiles>CCCCCC1=C/C(=C/c2[nH]c(-c3ccc[nH]3)cc2OC)N=C1C</smiles>

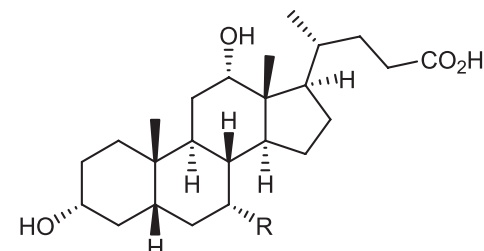<smiles>[R]c1[nH]c(=O)c([R])nc1/C=C/C(=O)O</smiles>

$8 \mathrm{R}_{1}=\mathrm{CH}\left(\mathrm{CH}_{3}\right)_{2}, \mathrm{R}_{2}=\mathrm{CH}_{2} \mathrm{OH}$

$9 \mathrm{R}_{1}=\mathrm{CH}\left(\mathrm{CH}_{3}\right)_{2}, \mathrm{R}_{2}=\mathrm{H}$

$10 \mathrm{R}_{1}=\mathrm{CH}\left(\mathrm{CH}_{3}\right)_{2}, \mathrm{R}_{2}=\mathrm{Me}$

$11 \mathrm{R}_{1}=\mathrm{CH}\left(\mathrm{CH}_{3}\right) \mathrm{CH}_{2} \mathrm{CH}_{3}, \mathrm{R}_{2}=\mathrm{CH}_{2} \mathrm{OH}$

Figure 1. Structures of cyclo-( $L$-Leu- $L$-Pro) (1), cyclo-( $L$-Phe-trans-4-OH- $L$-Pro) (2), cyclo-( $L$-Phe- $L$-Pro) (3) cyclo- $(L$-Trp- $L$-Pro) (4), prodigiosin (5), deoxycholic acid (6), cholic acid (7) and of giovaninones A-D (8-11). 
obtained from the sponge Arenosclera brasiliensis (Figure 2), and identified by analysis of spectroscopic data, including the assignment of absolute configuration by circular dichroism analysis. ${ }^{17}$ The production of bromotyrosine-derived metabolites by a marine bacterium provided strong evidence that such metabolites are likely not produced by sponges, as it has been repeteadly assumed in the past. ${ }^{18,19}$ The isolation of $\mathbf{1 2 - 1 4}$ from cultures of a Pseudovibrio Gram-negative bacterial strain illustrates the potential metabolic diversity of this particular group of marine bacteria, first described only ten years ago. ${ }^{20}$

Sponges harbor a high density of cyanobacteria and bacteria which may exceed those of surrounding seawater by up to three orders of magnitude. ${ }^{18}$ The microbiome composition of Aplysina sponges, the main source of bromotyrosine-derived metabolites, is rather homogeneous within the genus, ${ }^{21-23}$ but distinct to the environmental microbiome to which the sponges are exposed. ${ }^{24}$ One of the unique characteristics of the microbiome of Aplysina sponges is the high diversity and abundance of bacteria belonging to "Poribacteria" and Chloroflexi clades, ${ }^{19,21,22,25}$ bacterial groups which are considered true sponge symbionts ${ }^{26}$ and that present the enzymatic machinery for the biosynthesis of secondary metabolites..$^{27,28}$ Based on evidences that marine sponges share microbiomes with similar composition, it is possible that horizontal gene transfer between marine sponge symbionts is common. ${ }^{29}$ However, there is still no definitive evidences of exchange of genomic material between sponge-associated bacteria. ${ }^{29,30}$ On the other hand, colonization of sponges by bacteria found in surrounding seawater has been repeteadly observed, indicating that a bacterial interchange between species is a real possibility. ${ }^{26}$ Such evidences are supported by solid exprimental data indicating both vertically and horizontally bacterial transmission within and between sponge species. ${ }^{21,22,26,31}$

The importance of developing strategies for culturing marine bacteria, in particular sponge symbionts, must be stressed, ${ }^{21,22,26,32}$ since the large majority of sponge-associated microbial strains are considered to be resistant to cultivation ${ }^{26}$ or the secondary metabolism is difficult to be trigger. This is not only particularly relevant for the correct assignment of a microbial production of secondary metabolites,$^{30}$ along to the knowledge of microbial physiology and ecology of sponge symbionts ${ }^{22,26,31}$ but also for the detailed investigation of unique biosynthetic pathways which are not found elsewhere in nature but in sponges.

\subsection{Marine-derived fungi}

The destruxins [ $\beta$-Me-Pro] destruxin E chlrohydrin (15), destruxin E chlorohydrin (16), pseudodestruxin C (17), $\left[\mathrm{Phe}^{3}, N-\mathrm{Me}^{-\mathrm{Val}^{5}}\right]$ destruxin B (18), roseotoxin B (19), roseocardin (20), isariin (21) and isariin B (22) have been isolated from cultures of marine-derived Beauveria felina, obtained from the seaweed Caulerpa sp. (Figure 3). Cyclodepsipeptides $\mathbf{1 5}$ and $\mathbf{1 7}$ are new representatives of this class of metabolites. The structures of the metabolites have been established by analysis of spectroscopic data, while the absolute configuration of amino acids have been established by Marfey's analysis. ${ }^{33,34}$ This class of cyclodepsipeptides very often present potent and diverse bioactivities, including antitumoral, antiviral, cytotoxic, immunosuppressant and antiproliferative. Beauveria, Isaria and Metarrhizium fungi are entomopathogenic as a result of producing insecticide destruxins and other cyclodepsipeptides. ${ }^{35,36}$

Metabolites of disctinct biosynthetic pathways, including (E)-1-(2,3-dihydro-1H-pyrrol-1-yl)-2-methyldec8-ene-1,3-dione (23), 1-(2,3-dihydro-1H-pyrrol-1-yl)2-methyldecene-1,3-dione (24), citrinalin A (25), B (26) and citrinin (27), have been obtained from the culture media of Penicillium citrinum, also isolated from Caulerpa sp. (Figure 4). ${ }^{37}$ Biosynthetic investigations with the labelled precursors $\left[\mathrm{Me}-{ }^{13} \mathrm{C}\right]-L$-methionine, $\left[1-{ }^{13} \mathrm{C}\right]$ acetate, $\left[1,2-{ }^{13} \mathrm{C}\right]$ acetate, $\left[\mathrm{U}-{ }^{13} \mathrm{C}_{5}\right]-L$-proline and $\left[\mathrm{U}_{-}{ }^{13} \mathrm{C}_{5}\right]-L$-ornithine established that pyrrol-polyketides $\mathbf{2 3}$ and $\mathbf{2 4}$ are biosynthesized via the formation of a polyketide chain condensed with an ornithine residue and a methionine-derived methyl group. ${ }^{38}$ Similar experiments performed with $\left[\mathrm{Me}-{ }^{13} \mathrm{C}\right]-L$-methionine, $\left[1-{ }^{13} \mathrm{C}\right]-D$-glucose, $\left[\mathrm{U}-{ }^{13} \mathrm{C}\right.$ anthranilic acid, $\left[\mathrm{U}-{ }^{13} \mathrm{C}_{5}\right]-L$-proline and

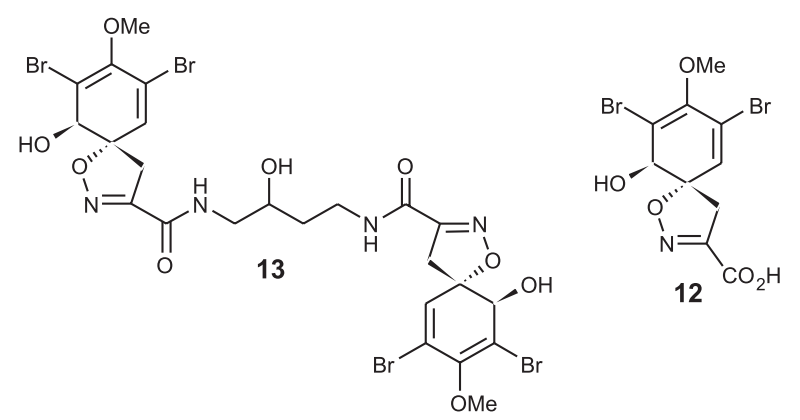<smiles>COC1=C(Br)[C@@H](O)[C@@]2(C=C1Br)CC(C(=O)NCC(O)c1cc(Br)c(OCC(O)CNC(=O)C3=NO[C@@]4(C=C(Br)C(OC)=C(Br)[C@@H]4O)C3)c(Br)c1)=NO2</smiles>

Figure 2. Structures of verongidoic acid (12), 11-hydroxyaerothionin (13) and fistularin-3 (14). 


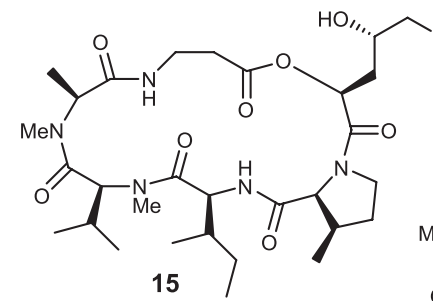<smiles>C=CC[C@@H]1OC(=O)CCNC(=O)[C@H](C)NC(=O)[C@H](C(C)C)NC(=O)[C@H](C(C)C)N1C(=O)[C@@H](NC(=O)[C@@H]1NCCC1C)C(C)C</smiles>

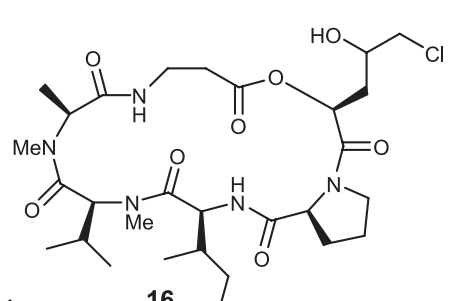

16<smiles>CC(C)C[C@H]1OC(=O)CCNC(=O)[C@@H](C(C)C)N(C)C(=O)[C@H](C(C)C)NC(=O)[C@H](Cc2ccccc2)NC(=O)[C@@H]2[C@H](C)CCN2C1=O</smiles><smiles>CC(C)C[C@H]1OC(=O)CCNC(=O)[C@@H](C(C)C)N(C)C(=O)[C@H](C(C)C)NC(=O)C(Cc2ccccc2)NC(=O)[C@@H]2CCCN2C1=O</smiles>

Figure 3. Structures of $[\beta-\mathrm{Me}-\mathrm{Pro}]$ destruxin E chlrohydrin (15), destruxin E chlorohydrin (16), pseudodestruxin C (17), $\left[\mathrm{Phe}{ }^{3}, N-\mathrm{Me}^{-V a l}{ }^{5}\right]$ destruxin B $(\mathbf{1 8})$, roseotoxin B (19), roseocardin (20), isariin (21) and isariin B (22).

$\left[\mathrm{U}-{ }^{13} \mathrm{C}_{5}\right]-L$-ornithine indicated that citrinalins $\mathrm{A}(\mathbf{2 5})$ and $\mathrm{B}$ (26) are derived from a mixed biosynthetic pathway from isoprene units, ornithine and tryptophan, via anthranilic acid. ${ }^{39}$ The isolation of citrinalin $\mathrm{C}(\mathbf{2 8})$ provided support for a biosynthetic pathway suggested for citrinalins (Scheme 1).

Meleagrine (29) and oxaline (30) were isolated from cultures of a strain of $P$. oxalicum obtained from marine sediments (Figure 4). ${ }^{37}$ The biosynthesis of both 29 and 30 involves the intermediation of roquefortine $\mathrm{L}$ (31) (Scheme 2), itself a product of transformation of roquefortine $\mathrm{C}(\mathbf{3 2})$ by oxaD, an efficient nitronase of P. oxalicum expressed heterologously by E. coli. ${ }^{40}$

A series of polyketide-derived and terpene-derived fungal metabolites have been isolated from cultures of different fungal strains (Figure 5). Cultures of Penicillium sp. isolated from the ascidian Didemnum granulatum presented 13-desoxy-phomenome (33), identified by analysis of spectroscopic data. Sponge-derived $P$. raistrickii produced norliquexanthone (34), while an algae-derived Penicillium stecki strain produced $(S)$-8-methoxy3,5-dimethylisochroman-6-ol (35). Roridin A (36) has been<smiles>Nc1ccccc1C(=O)O</smiles>

anthranilic acid

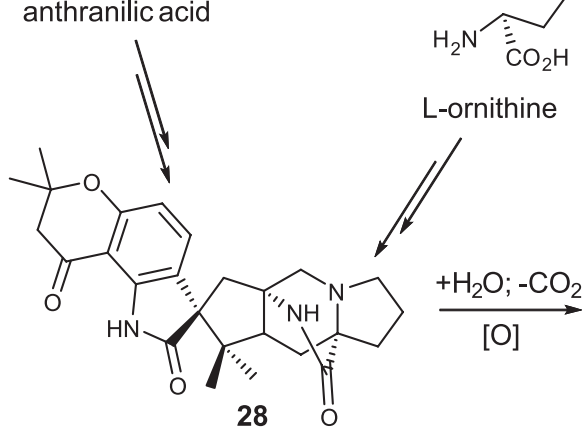

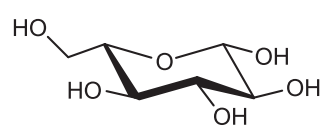

D-glucose
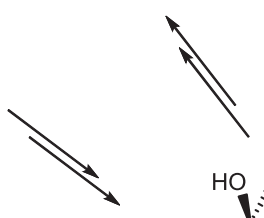<smiles>CC1(C)CC(=O)c2c(ccc3c2NC(=O)[C@]32C[C@]3([N+](=O)[O-])CN4CCC[C@H]4C[C@H]3C2(C)C)O1</smiles>

$26 \beta-\mathrm{NO}_{2}$<smiles>C[C@@H](O)CC(=O)O</smiles>

Scheme 1. Biosynthesis of citrinalins. ${ }^{39}$ 
<smiles>[Z4]C(C(=O)CCCCCCC)C(=O)N1C=CCC1</smiles>

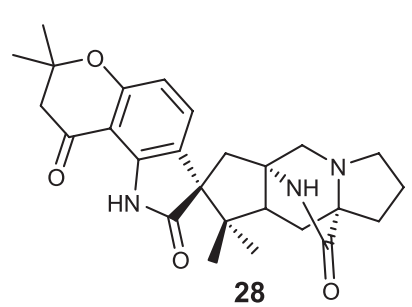
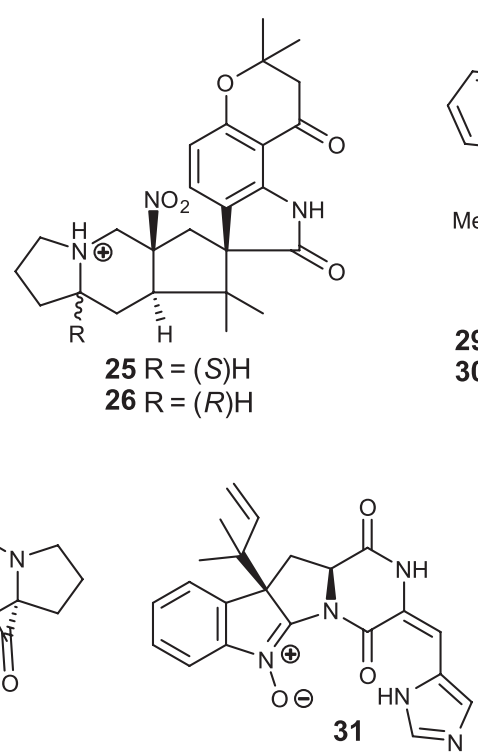<smiles>[R2]OC1=C[C@@]2(C(C)(C)C=C)c3ccccc3N(OC)[C@@]23NC(=O)/C(=C\c2c[nH]cn2)N3C1=O</smiles><smiles>[Z7]C1=C(C)C(=O)C(C(=O)O)=C(O)C1=COC(C)C</smiles>

Figure 4. Structures of (E)-1-(2,3-dihydro-1H-pyrrol-1-yl)-2-methyldec-8-ene-1,3-dione (23), 1-(2,3-dihydro-1H-pyrrol-1-yl)-2-methyldecene1,3-dione (24), citrinalin A (25), B (26), citrinin (27), citrinalin C (28), meleagrine (29), oxaline (30), roquefortine L (31) and roquefortine C (32).<smiles>O=C1NC(Cc2cnc[nH]2)C(=O)NC1Cc1cnc[nH]1</smiles><smiles>C=CC(C)(C)C1CC(=O)NC(Cc2cnc[nH]2)C1=O</smiles>

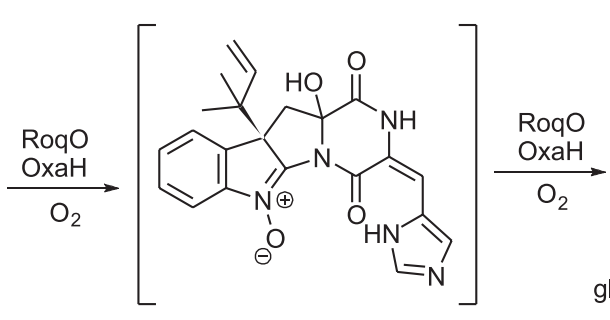<smiles>C=CC1(C(C)(C)C)CC2C(=O)N/C(=C/c3cnc[nH]3)C(=O)N2C1Nc1ccccc1</smiles>

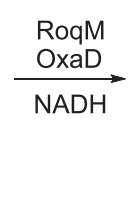<smiles>C=CC(C)(C)C12CC(=O)N/C(=C\c3cnc[nH]3)C(=O)N1C2ON([O])c1ccccc1</smiles><smiles>C=CC(C)(C)[C@]12C[C@H]3C(=O)N/C(=C/c4cnc[nH]4)C(=O)N3C1Nc1ccccc12</smiles>

2<smiles>[R][R15](=O)C([R16])C</smiles>

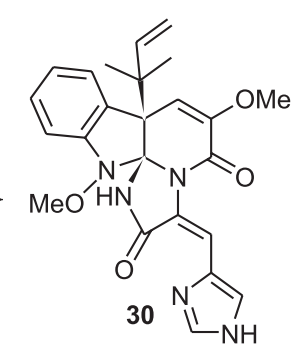

Scheme 2. Biosynthesis of maleagrin (29) and oxaline (30) via roquefortine L (31). ${ }^{40}$

isolated from cultures of Trichoderma sp., while cultures of the fungus $P$. paxilli provided pyrenocine A (37), B (38) and the new pyrenocine $\mathrm{J}(\mathbf{3 9})$, identified by analysis of spectroscopic data. ${ }^{41}$ Compound $\mathbf{3 7}$ displayed antiviral activity against Herpes Simplex virus type-1 (HSV-1) and avian metapneumovirus (AMPV) with $\mathrm{EC}_{50}$ at 4.2 and $63.27 \mu \mathrm{g} \mathrm{mL} \mathrm{m}^{-1}$, respectively. Pyrenocine A (37) also showed cytotoxic activity $(3-5 \mu \mathrm{g} \mathrm{mL}-1)$. $^{42,43}$

The marine-derived fungus Phomopsis longicolla obtained from the seaweed Bostrychia radicans produced the known 18-deoxycytochalasin H (40, Figure 6), mycophenolic acid (41, Figure 6) and dicerandrol C (42, Figure 6). Compound $\mathbf{4 2}$ displayed antimicrobial activity against $S$. aureus and $S$. saprophyticus with $\mathrm{IC}_{50}$ at 1.33 and $2.66 \mu \mathrm{M}$, respectively. ${ }^{44}$

Cultures of Aspergillus sp. isolated from the ascidian Eudistoma vannamei provided the known polyketides $(R)$-mellein (43, Figure 7), penicillic acid (44, Figure 7), cis-4-hydroxymellein (45, Figure 7) and trans-4-hydroxymellein (46, Figure 7). Compound 44 displayed moderate cytotoxic activity against MDA-MB-435 and HCT- 8 with $\mathrm{IC}_{50}$ at 4.43 and $8.76 \mu \mathrm{g} \mathrm{mL}^{-1}$, respectively. ${ }^{45}$ A co-culture of marine-derived Penicillium sp. and Trichoderma sp. isolated from the marine sponges Mycale angulosa and Geodia corticostylifera, respectively, yielded two novel polyketides (Figure 7), (Z)-2-ethylhex2-enedioic acid (47) and (E)-4-oxo-2-propylideneoct-7-enoic $\operatorname{acid}(\mathbf{4 8}){ }^{46}$

A strain of Aspergillus sp. isolated from marine sediments produced the known metabolites pseurotins A (49, Figure 8), D (50, Figure 8), FD-838 (51, Figure 8), fumitremorgin C (52, Figure 8), 12,13-dihydroxy- 
<smiles>CC(=O)C12OC1C1(C)C(=CC2=O)CCC(O)C1C</smiles><smiles>C/C=C/C(=O)c1c(OC)cc(=O)oc1C</smiles><smiles>Cc1cc(O)cc2oc3cc(O)cc(O)c3c(=O)c12</smiles><smiles>COc1cc(O)c(C)c2c1CO[C@H](C)C2</smiles>

35

Figure 5. Structures of 13-desoxy-phomenome (33), norliquexanthone (34), (S)-8-methoxy-3,5-dimethylisochroman-6-ol (35), roridin A (36), pyrenocines A (37), B (38) and J (39).

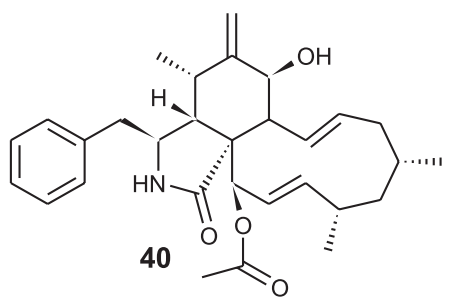<smiles>[Z14]c1c(C)c2c(c(O)c1C/C=C(\C)CCC(=O)O)C(=O)OC2</smiles><smiles>CC(=O)OC[C@@]12OC(=C(O)CC1C)C(=O)c1c(ccc(-c3ccc4c(c3O)C(=O)C3=C(O)CC(C)[C@@H](OC(C)=O)[C@@]3(COC(C)=O)O4)c1O)[C@H]2OC(C)=O</smiles>

Figure 6. Structures of 18-deoxycytochalasin H (40), mycophenolic acid (41) and dicerandrol C (42).<smiles>C[C@H]1Cc2cccc(O)c2C(=O)O1</smiles>

43<smiles>C=C(C)C1(O)OC(=O)C=C1OC</smiles><smiles>C[C@H]1OC(=O)c2c(O)cccc2[C@@H]1O</smiles><smiles>C[C@H]1OC(=O)c2c(O)cccc2[C@@H]1O</smiles><smiles>CCC/C(=C/CCC(=O)[17F])C(=O)O</smiles><smiles>C=CCCC(=O)C/C(=C\CC)C(=O)O</smiles>

Figure 7. Structures of $(R)$-mellein (43), penicillic acid (44), cis-4-hydroxymellein (45), trans-4-hydroxymellein (46), (Z)-2-ethylhex-2-enedioic acid (47) and (E)-4-oxo-2-propylideneoct-7-enoic acid (48).

fumitremorgin C (53, Figure 8), methylsulochrin (54, Figure 8) and bis(dethio)bis(methylthio)gliotoxin (55, Figure 8). Compounds $\mathbf{5 2}$ and $\mathbf{5 3}$ displayed weak cytotoxic activity against $\mathrm{HCT}-116$ cells with $\mathrm{IC}_{50}$ at 15.17 and $4.53 \mu \mathrm{M}$, respectively. ${ }^{47}$ The known cytochalasin D
(56, Figure 8) has been isolated from cultures of Xylaria sp. obtained from the seaweed Bostrychia tenella. ${ }^{48}$

The marine-derived fungus Roussoella sp. produced a novel polyketide named roussoelatide (57), which structure and absolute configuration were established by analysis

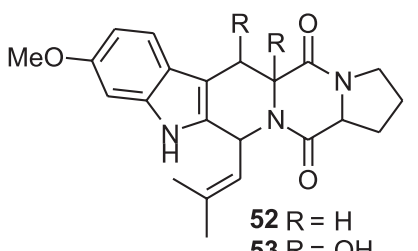<smiles>COc1cc(C)cc(OC)c1C(=O)c1c(OC)cc(O)cc1C(C)=O</smiles>
$53 \mathrm{R}=\mathrm{OH}$<smiles>[R]C(C)/C=C\C(O)C(O)C1=C(C)C(=O)C2(O1)C(=O)NC(OC)(C(=O)c1ccccc1)C2O</smiles><smiles>CCc1ccc(C2=C(C)C(=O)C3(O2)C(=O)NC(O)(C(=O)c2ccccc2)C3O)o1</smiles>

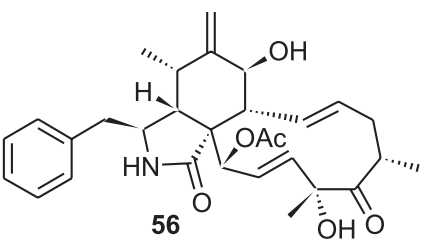<smiles>Cc1ccc(O)c2c1C[C@H](C)OC2=O</smiles><smiles>COc1c(Cl)c(O)c2c(c1Cl)CC(C)OC2=O</smiles>

Figure 8. Structures of pseurotins A (49), B (50), FD-838 (51), fumitremorgin C (52), 12,13-dihydroxy-fumitremorgin C (53), methylsulochrin (54), bis(dethio) bis(methylthio)gliotoxin (55), cytochalasin D (56), 5-methylmellein (58) and 5,7-dichloro-3-methyl-6-methoxy-8-hydroxy-3,4-dihydroisocoumarin (59). 
of spectroscopic data and X-ray diffraction analysis. Biosynthesis of $\mathbf{5 7}$ was investigated using ${ }^{13} \mathrm{C}$-labeled sodium acetate, indicating a unique pathway including two Favorskii-like rearrangements and an intermolecular Diels-Alder reaction (Scheme 3). ${ }^{49}$ The same marine-derived fungus produced the known compounds 5-methylmellein (58) and 5,7-dichloro-3-methyl-6-methoxy-8-hydroxy3,4-dihydroisocoumarin (59) ${ }^{43}$ (Figure 8).

A marine-derived Penicillium sp. strain isolated from the sponge Dragmacidon reticulatum (Figure 9) provided cultures with the known 15(S)-10,11-dehydrocurvularin (60) along with seven new compounds $15(S)$-12-keto-10,11-dehydrocurvularin (61), 15(S)-cis-10,11-epoxycurvularin (62), $10(R), 11(R), 15(S), 18(S)$-cyclothiocuvularin A $(\mathbf{6 3})$, $10(S), 11(S), 15(S), 18(R)$-cyclothiocuvularin B $(\mathbf{6 4})$, the methyl esther (65), 15(S),18(S)-cyclosulfoxicurvularin (66) and its methyl esther (67). Structures were established by analysis of spectroscopic data and by X-ray diffraction analysis. Feeding experiments using ${ }^{13} \mathrm{C}$-labelled $L$-cysteine indicated that compounds 63-65 are likely detoxification products induced by overproduction of $\mathbf{6 0}$ in the presence of $L$-cysteine. ${ }^{50}$

Aspergillus sydowii isolated from the sponge $D$. reticulatum produced the known sydowic acid (68, Figure 10) in culture media. The new (-)-naphthoquinoneimine (69, Figure 10) along with seven known compounds (Figure 10), aurosperone A (70), aurosperone C (71), pyranonigrins B (72), C (73), pyrophen (74), leucomelone (75) and atromentin (76), have been isolated from culture media of Aspergillus sp. obtained from the ascidian Didemnum ligulum.

A marine-derived strain of the fungus Penicillium glabrum isolated from the same ascidian procuded in culture medium penicitrinone A (77, Figure 11), pinselin (78, Figure 11) and emodin (79, Figure 11), while a marine-derived $P$. citrinum produced 79, quinolactacin B (80, Figure 11) and C (81, Figure 11), penicillenol A1 (82, Figure 11) and citreorosein (83, Figure 11). Three known metabolites, (+)-abscisic acid (84), 4-hydroxy-3-(3-methylbut-2-enyl)benzoic acid (85) and anofinic acid (86), and the new 2,3-dihydro6,7-dihydroxy-2,2-dimethylchromen-4-one (87), were

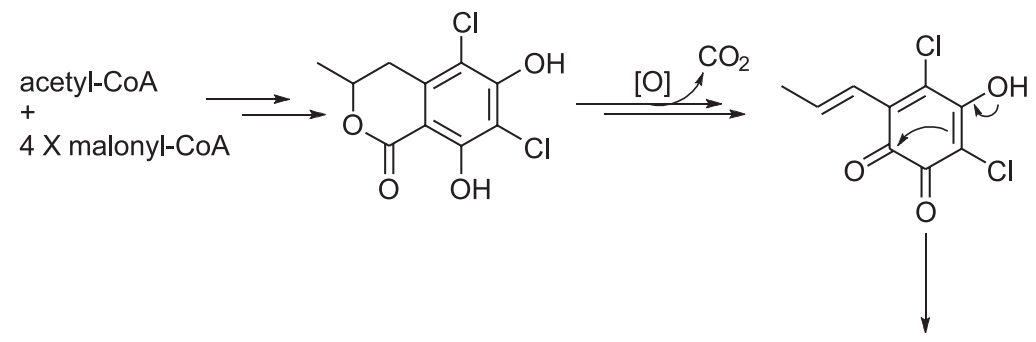

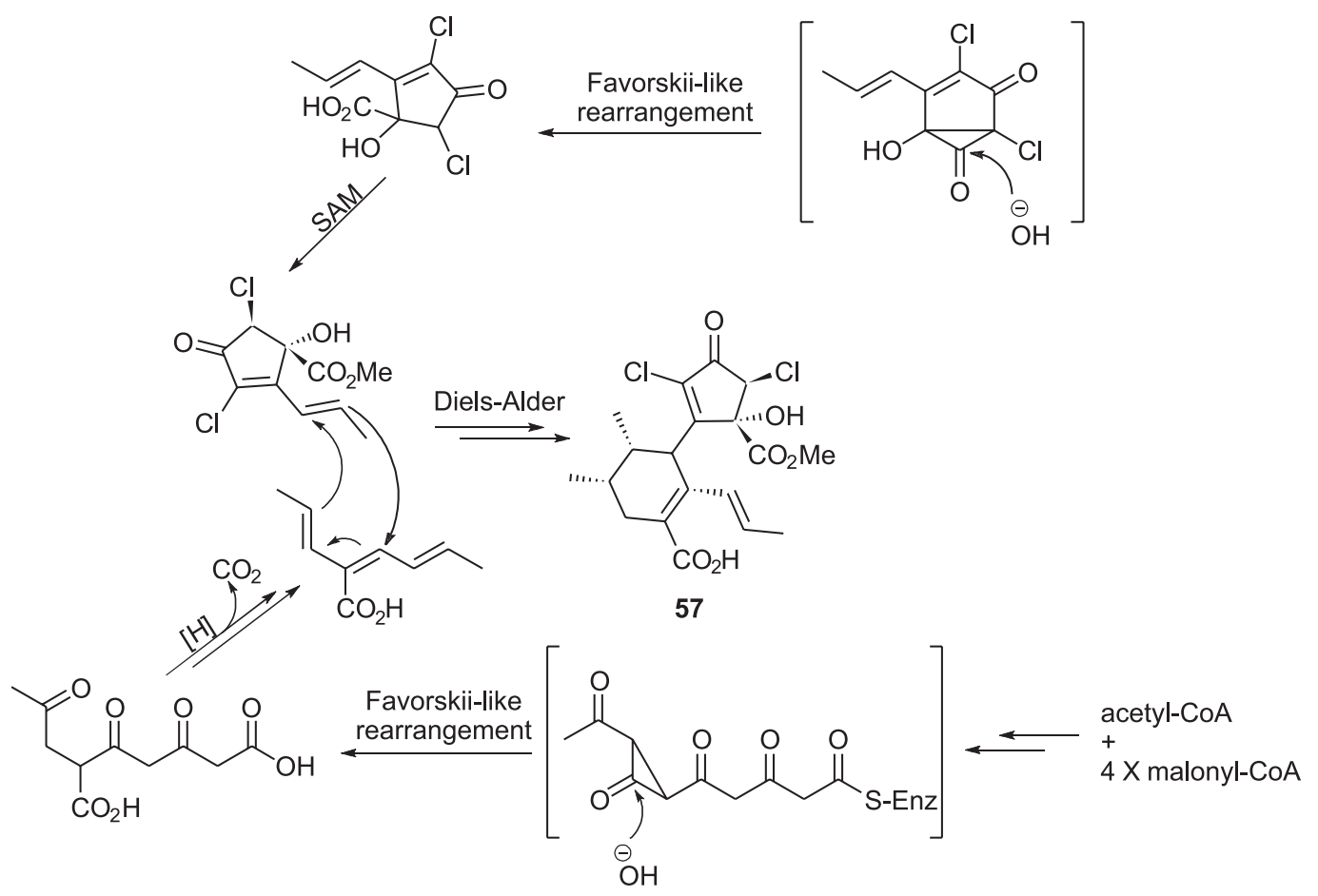

Scheme 3. Biosynthesis of roussoellatide (57). ${ }^{49}$ 


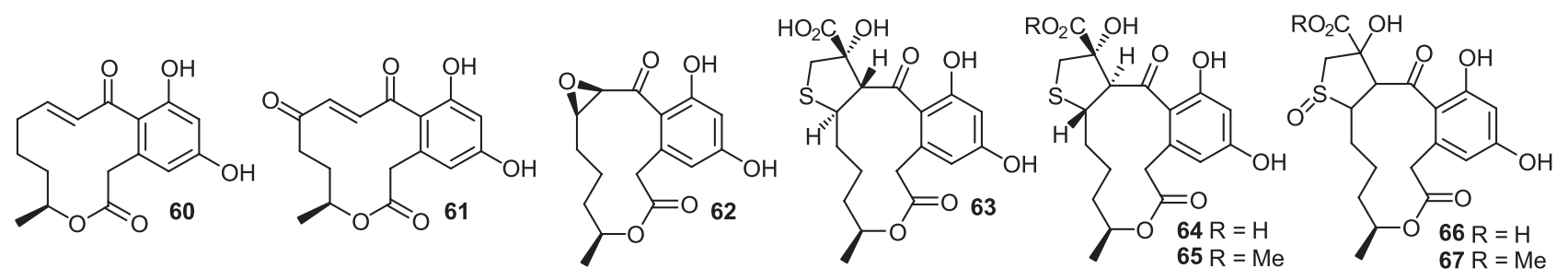

Figure 9. Structures of 15(S)-10,11-dehydrocurvularin (60), 15(S)-12-keto-10,11-dehydrocurvularin $(\mathbf{6 1})$, 15(S)-cis-10,11-epoxycurvularin $(\mathbf{6 2})$, $10(R), 11(R), 15(S), 18(S)$-cyclothiocuvularin A $(\mathbf{6 3}), 10(S), 11(S), 15(S), 18(R)$-cyclothiocuvularin B $(\mathbf{6 4})$, the methyl esther $(\mathbf{6 5})$, $15(S), 18(S)$-cyclosulfoxicurvularin $(\mathbf{6 6})$ and its methyl esther $(\mathbf{6 7})$.

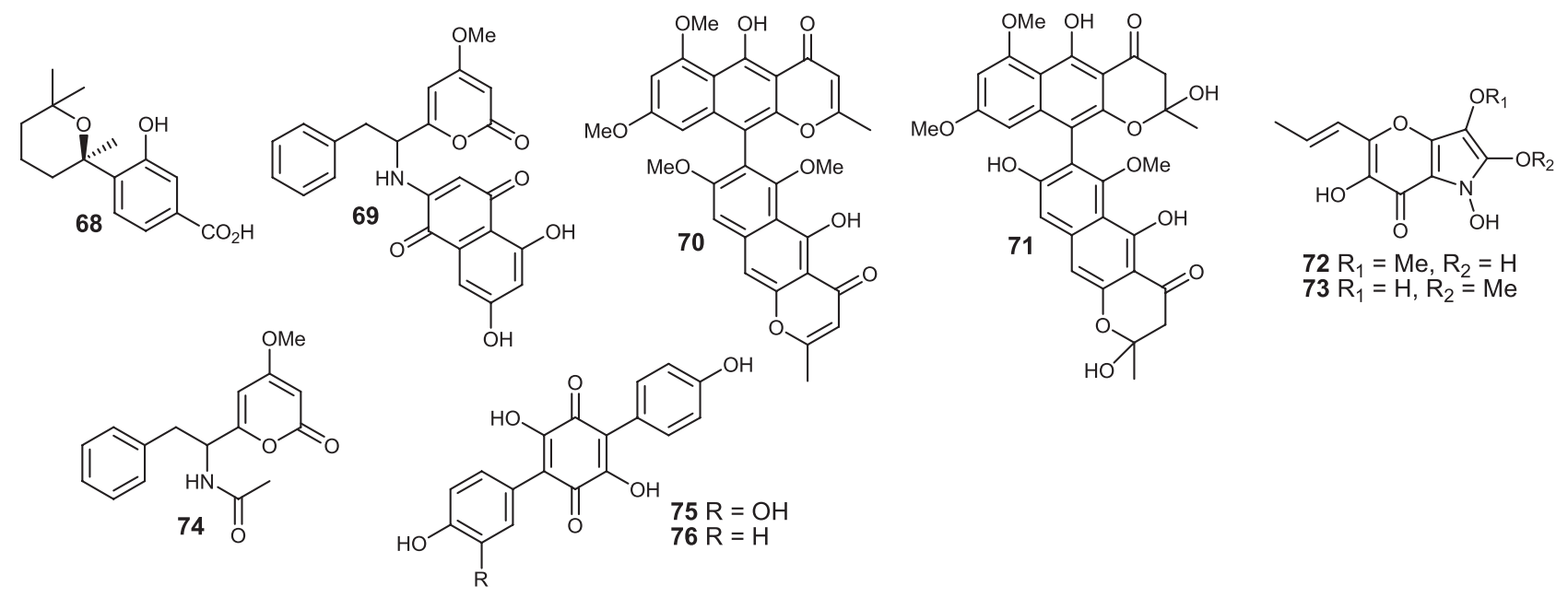

Figure 10. Structures of sydowic acid (68), (-)-naphthoquinoneimine (69) along with seven known compounds, aurosperone A (70), aurosperone C (71), pyranonigrins B (72), C (73), pyrophen (74), leucomelone (75) and atromentin (76).

isolated from cultures of Cochliobolus sp., isolated from the sponge Mycale laxissima. A strain of Trichoderma sp., also obtained from $M$. laxissima, produced in culture harzianopyridone (88, Figure 11). Compounds 69, 79 and 83 displayed moderate antiviral activity. Harzianopyridone (88) was active against HSV-1 $\left(\mathrm{EC}_{50}\right.$ at $\left.0.2 \mu \mathrm{g} \mathrm{mL}^{-1}\right)$ with low toxicity $\left(34 \mu \mathrm{g} \mathrm{mL}^{-1}\right)$ and high selectivity. This compound also showed inhibition of virus HSV-1 KOS, an acyclovir resistant lineage. Compound $\mathbf{7 9}$ was active against hepatitis $\mathrm{C}$ virus at $\mathrm{IC}_{50} 2.5 \mu \mathrm{g} \mathrm{mL} \mathrm{m}^{-1}{ }^{43}$

\section{Marine Invertebrates}

Marine invertebrates collected along the Brazilian coastline for chemical and pharmacological investigation have a large extension of redundancy with invertebrates collected in the past in the Caribbean region. Such redundancy led to the isolation of several known compounds, $70 \%$ of which are aminoacid-derived.

\subsection{Marine sponges}

The new bis-piperidine alkaloid ingenamine $G(\mathbf{8 9}$, Figure 12) has been isolated from the marine sponge
Pachychalina alcaloidifera. Ingenamine G (89) displayed cytotoxic activity against HCT-8 (colon), B16 (leukemia) and MCF-7 (breast) at 8.6, 9.8 and $11.3 \mu \mathrm{g} \mathrm{mL}^{-1}$, respectively. ${ }^{51}$ Investigation on the cytotoxic mechanismof-action of compound $\mathbf{8 9}$ indicated that it promotes DNA-damage, especially in S-phase of the cell-cycle..$^{52}$ Ingenamine $\mathrm{G}$ also displayed antibacterial action with $\mathrm{IC}_{50}$ at 105.0, 75.0, 10-50 and $8.0 \mu \mathrm{g} \mathrm{mL}^{-1}$ against Staphylococcus aureus, Escherichia coli, S. aureus oxacillin-resistant and Mycobacterium tuberculosis, respectively.

The $n$ - $\mathrm{BuOH}$ extract of $P$. alcaloidifera yielded a mixture of eleven 3-alkylpyridine compounds, cyclostellettamines A-I, K and L (90-100), among which alkaloids 96-100 are new representatives of this class. Cyclostellettamines 90-100 were identified by high performance liquid chromatography-mass spectrometry (HPLC-MS/MS) analyses. ${ }^{51}$ The antimicrobial activity of 90-100 were also investigated, suggesting that the distance between the two pyridinium moieties of cyclostellettamines are important for the antibacterial activity against different pathogenic bacterial and fungal strains ${ }^{53}$ Futher studies on the secondary metabolites from P. alcaloidifera led to the isolation of mandangamine $\mathrm{F}$ (101, Figure 12), haliclonacyclamine (102, Figure 12), arenosclerin D (103, Figure 12) and E (104, Figure 12). All these 


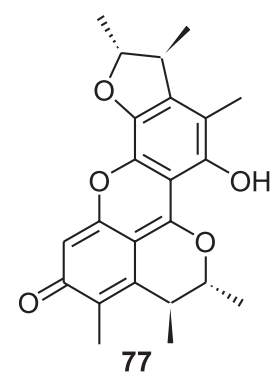<smiles>CC(=O)c1c(O)ccc2oc3cc(C)cc(O)c3c(=O)c12</smiles>

78<smiles>[R]c1cc(O)c2c(c1)C(=O)c1cc(O)cc(O)c1C2=O</smiles>

$83 \mathrm{R}=\mathrm{CH}_{2} \mathrm{OH}$<smiles>CCCCCCC(C)/C(O)=C1/C(=O)[C@@H](C(C)O)N(C)C1=O</smiles><smiles>CC1=CC(=O)CC(C)(C)C1(O)/C=C/C(C)=C\C(=O)O</smiles><smiles>CC(C)=CCc1cc(C(=O)O)ccc1O</smiles><smiles>CC1(C)C=Cc2cc(C(=O)O)ccc2OC1(C)C</smiles><smiles>C/C=C/CC(C)C(=O)c1c(O)c(OC)c(OC)[nH]c1=O</smiles>

Figure 11. Structures of penicitrinone A (77), pinselin (78), emodin (79), quinolactacin B (80) and C (81), penicillenol A1 (82), citreorosein (83), (+)-abscisic acid (84), 4-hydroxy-3-(3-methylbut-2-enyl)benzoic acid (85), anofinic acid (86), new 2,3-dihydro-6,7-dihydroxy-2,2-dimethylchromen-4-one (87) and harzianopyridone (88).

alkaloids presented moderated cytotoxic activity against SF295, MDA-MD435, HCT8 and HL60 cell lineages. ${ }^{54}$

The polycyclic aromatic alkaloid 4-methylaaptamine (105, Figure 13) was isolated from the extract of Aaptos aaptos and displayed anti-viral activity by inhibiting the replication of HSV- $1 .{ }^{55}$ The sponge Haliclona tubifera provided the known halisphingosine A (106, Figure 13) and the new halisphingosine B (107, Figure 13), long-chain sphingoid bases derivatives, which possess an uncommon $L$-threo configuration for this class of natural products..$^{56}$ Cyclic alkylpyridine oligomers (Figure 13) haliotoxin (108) and amphitoxin (109) have been isolated from the marine sponge Amphimedon sp. and displayed antifungal activity against Aspergillus flavus, a storage contaminant fungus affecting for commercial agricultural products. The mixture of $\mathbf{1 0 8}$ and $\mathbf{1 0 9}$ showed a MIC (minimum inhibitory concentration) in the range of $1.9-15.6 \mu \mathrm{g} \mathrm{mL}^{-1}$ and MFC (minimum fungicidal concentration) between 3.9-31.3 $\mu \mathrm{g} \mathrm{mL}^{-1}$ against eleven strains of A. flavus. ${ }^{57}$

The sponge Cliona delitrix yielded the neurotransmitter serotonin (110, Figure 14). ${ }^{58}$ Four known halogenated depsipeptides (Figure 14), geodiamolides A (111), B (112), $\mathrm{H}$ (113) and I (114) have been isolated from the $\mathrm{MeOH}$ extract of Geodia corticostylifera. ${ }^{59}$ Geodiamolides are

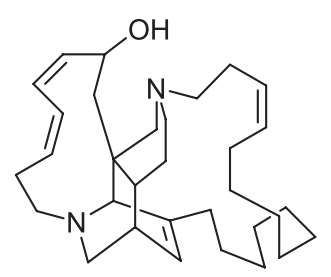

89

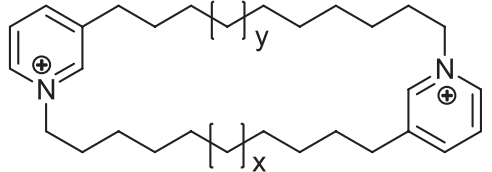

$90 x=3, y=3 \quad 96 x=2, y=3$

$91 \mathrm{x}=3, \mathrm{y}=4 \quad 97 \mathrm{x}=1, \mathrm{y}=3$

$92 \mathrm{x}=4, \mathrm{y}=4 \quad 98 \mathrm{x}=1, \mathrm{y}=4$

$93 x=3, y=5 \quad 99 x=1, y=5$

$94 x=4, y=5 \quad 100 x=2, y=5$

$95 x=5, y=5$
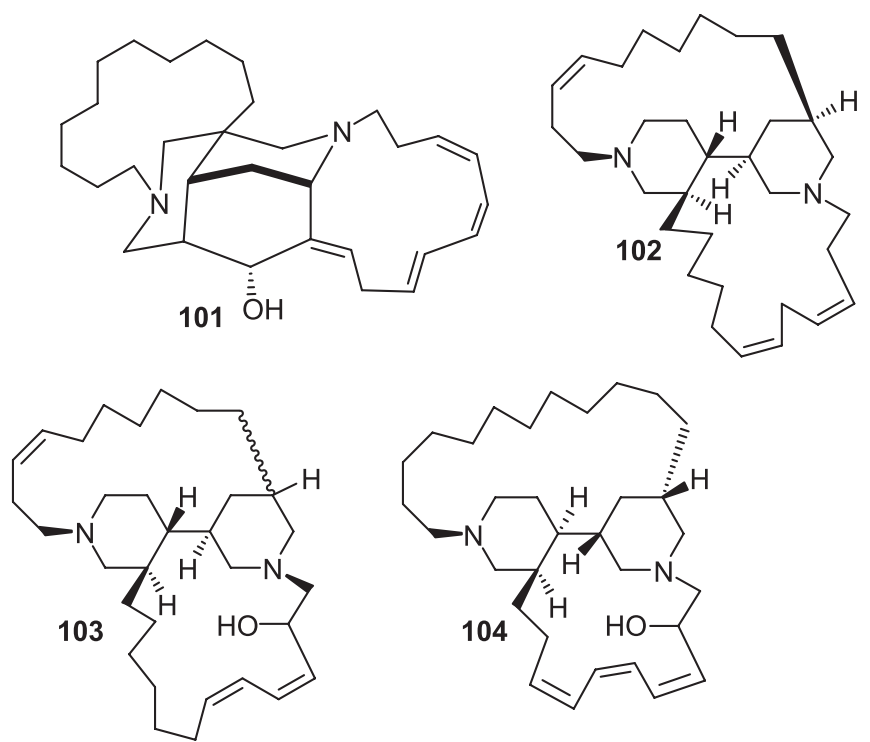

Figure 12. Structures of ingenamine G (89), cyclostellettamines A-I, K and L (90-100), mandangamine F (101), haliclonacyclamine (102), arenosclerins D (103) and E (104). 
<smiles>COc1cc2ccn3c4ccnc(c14)c23</smiles>
$105 \mathrm{Me}$<smiles>CCCCCCCCCCCC[C@H](O)CC[C@@H](O)[C@H](N)CO</smiles><smiles>CC(C)CCC[n+]1cccc(CC[Al]c2ccc[n+](CCC(C)C)c2)c1</smiles>

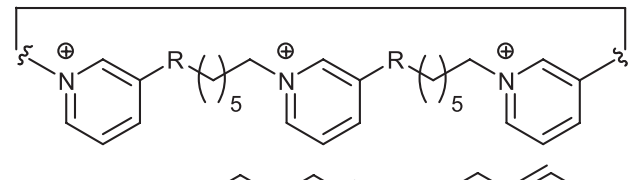<smiles>[Y9]CCCCCCCC=CC</smiles>

Figure 13. Structures of 4-methylaaptamine (105), halisphingosine A (106), halisphingosine B (107), haliotoxin (108) and amphitoxin (109).

known to disassemble actin microfilaments. ${ }^{60}$ In the case of compounds 111-114, they presented antiproliferative activity against breast cancer cells, with $\mathrm{EC}_{50}$ ranging among 9.82 and $115.3 \mathrm{nM}$, and did not affect healthy cells. ${ }^{59}$

Guanidine alkaloids isolated from marine sponges are unique for their chemical structures and biological activities. ${ }^{61-68}$ The extract of the sponge Monanchora aff. arbuscula provided isoptilocaulin (115, Figure 15), which displayed antimicrobial activity against $S$. aureus oxacillin-resistant at $1.3 \mu \mathrm{g} \mathrm{mL}{ }^{-1} .^{69}$ Mirabilin B (116, Figure 15), 8 $\beta$-hydroxyptilocaulin (117, Figure 15), ptilocaulin (118, Figure 15) and the $8 \beta$ and $8 \alpha$-epimers mixture of 8-hydroxymirabilin (119-120, Figure 15) have been obtained from M. arbuscula. Alkaloids $\mathbf{1 1 7}$ and $\mathbf{1 1 8}$ presented weak cytotoxic activity against HL60 at 7.89 and $5.77 \mu \mathrm{M}, \mathrm{HCT}-8$ at 19.0 and $17.69 \mu \mathrm{M}$ and MDA-MB-435 at 11.34 and $7.58 \mu \mathrm{M}$, respectively. Ptilocaulin (118) induces apoptosis in HL60 cell lineage. ${ }^{70}$

Further investigations on the minor compounds of M. arbuscula extract led to the isolation of monalidine A (121, Figure 15), arbusculidine A (122, Figure 15), batzellamide A (123, Figure 16), hemibatzelladine J (124,<smiles>NCCc1c[nH]c2ccc(O)cc12</smiles>

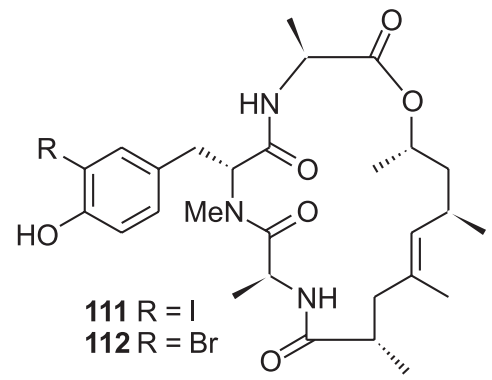

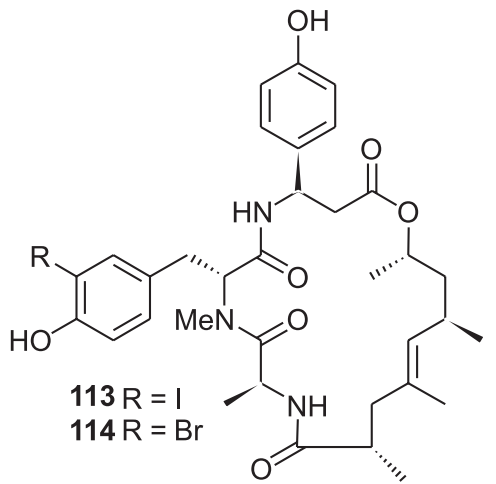

Figure 14. Structures of serotonin (110), geodiamolides A (111), B (112), H (113) and I (114).<smiles>CCCCC1=C(C)C[C@H]2CC[C@@H]3NC(=O)N[C@]132</smiles><smiles>CCCC[C@@H]1C[C@@H]2C[C@H](C)C3=C2NC(=N)NC31</smiles>

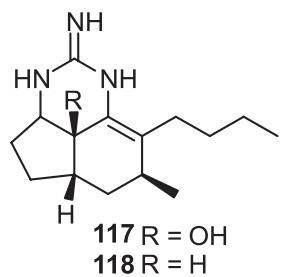

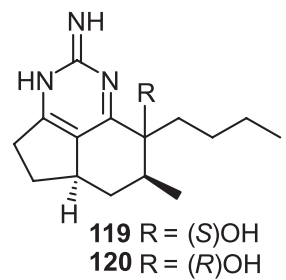<smiles>CCCCCCCCCC1=CC2=CCCCN2C(=N)N1</smiles>

Figure 15. Structures of isoptilocaulin (115), mirabilin B (116), $8 \beta$-hydroxyptilocaulin (117), ptilocaulin (118), of the $8 \beta$ and $8 \alpha$-epimers mixture of 8-hydroxymirabilin (119-120), monalidine A (121) and arbusculidine A (122). 


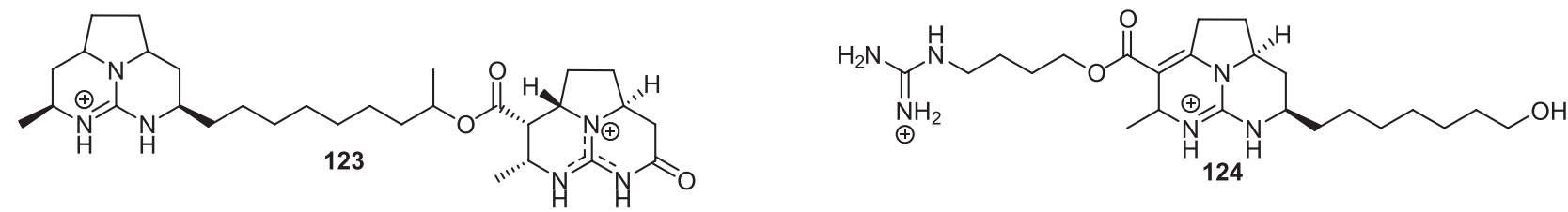<smiles>[R]C[C@H]1C[C@H]2CCC3=C(C(=O)OCCCCNC(=N)N)C(C)CN=C(N1)N32</smiles><smiles>CCCCCCCCC[C@@H]1C[C@H]2CC[C@]3(C(=O)OCCCCNC(=N)N)[C@@H](C)NC(=N2)N3O1</smiles>

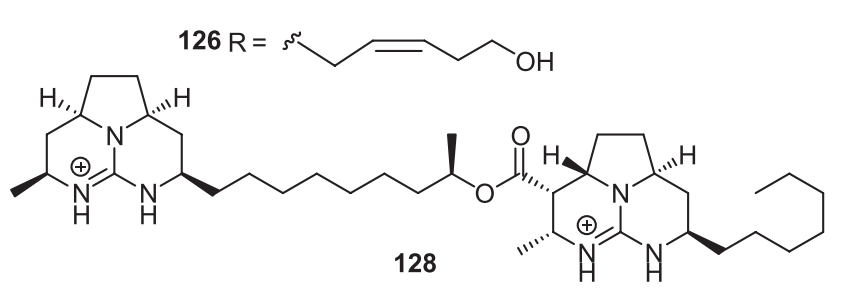

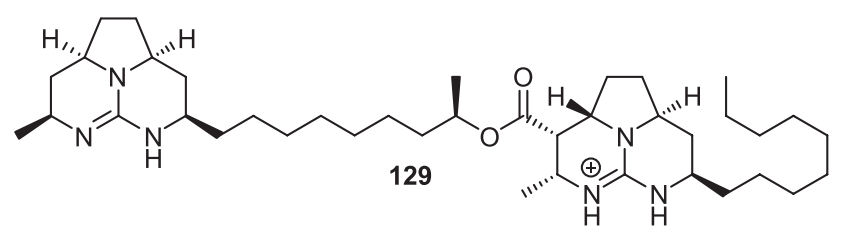

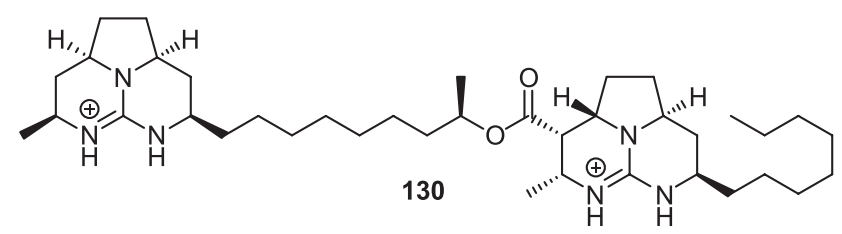

Figure 16. Structures of batzellamide A (123), hemibatzelladine J (124), $\Delta^{19}$-hemibatzelladine J (125), $\Delta^{20}$-hemibatzelladine J (126), batzelladines D (127), F (128), L (129) and nor-L (130).

Figure 16), $\Delta^{19}$-hemibatzelladine $\mathbf{J}(\mathbf{1 2 5}$, Figure 16) and $\Delta^{20}$-hemibatzelladine $\mathbf{J}$ (126, Figure 16), along with the known batzelladines D (127, Figure 16), F (128, Figure 16), L (129, Figure 16) and nor-L (130, Figure 16). Alkaloids 126-129 presented potent antiparasitic activity against Trypanosoma cruzi and Leishmania (L.) infantum, ${ }^{71}$ while 129 also showed antifungal activity against $A$. flavus with MIC 1.9-7.8 $\mu \mathrm{M} \mathrm{mL}^{-1}$ and MFC 3.9-15.6 $\mu \mathrm{g} \mathrm{mL}^{-1} .{ }^{.7}$

Bromotyrosine-derived sponge metabolites are some of the very first natural products isolated from marine sponges. In the past, these metabolites were considered as chemotaxonomic markers for sponges belonging to the order Verongida. ${ }^{72}$ However, the isolation of several of these metabolites from many sources other than sponges within the order Verongida ${ }^{17,73}$ challenged previous assumptions on the actual origin of these metabolites. ${ }^{17}$

The $\mathrm{MeOH}$ extract of the sponge Verongula gigantea yielded the known (Figure 17) 2-(3,5-dibromo4-methoxyphenyl)- $N, N, N$-dimethylethanammonium (131) and 2,6-dibromo-4-(2-(trimethylammonium)ethyl)phenol (132) ${ }^{58}$ Further investigation on the metabolites of the marine sponge Aplysina caissara led to the isolation of the new agelocaissarines A1 (133, Figure 17), A2 (134, Figure 17), B1 (135, Figure 17), B2 (136, Figure 17) and caissarine C (137, Figure 17), together with the known 11-hydroxyaerothionin
(13, Figure 2) and fistularin-3 (14, Figure 2). ${ }^{74}$ Compound 14, 11-deoxyfistularin-3 (138) and the new 2-(3-amino2,4-dibromo-6-hydroxyphenyl)acetic acid (139) have been isolated from A. cauliformis (Figure 17). Bromotyrosines 14, 138 and 139 displayed antituberculosis activity against Mycobacterium tuberculosis at 7.1, 7.3 and $49 \mu \mathrm{M}$, respectively. ${ }^{73}$ The new 3-(3,5-dibromo-4-methoxyphenyl2-methoxy- $N$-methylpropan-1-ammonium (140, Figure 17) was isolated from the sponge Pachychalina sp., the only Haplosclerida sponge source of a bromotyrosinederived compound. ${ }^{73}$ The $\mathrm{MeOH}$ extract of Aplysina sp. provided 131, (3',5'-dibromo-4'-ethoxy-1'-hydroxy4'-methoxycycloexa-2',5'-dienyle)acetamide (141, Figure 17), aeroplysinin-2 (142, Figure 17), ethyl ester of 2,4-dibromo-1-hydroxy-3-methoxy-6-oxa-3-azaspiro [4.5]dec-2,4,8-trieno-8-carboxylate (143, Figure 17) and $\left(R^{*}, S^{*}\right)$-[3,5-dibromo-4-(2-oxo-5-oxazolidinyl) methoxyphenyl]-2-oxazolidinone (144, Figure 17) ${ }^{69}$

The chemical profile of Aplysina fulva collected in different locations along the Brazilian coastline was investigated (Figure 18). A. fulva collected at Angra dos Reis, Rio de Janeiro State, Brazil, yielded 14, 144 and cavernicolins-1 (145) and -2 (146). A. fulva sampled in Salvador, Bahia State, provided the new bromotyrosine aplysinafulvin (147), along with 148, 11-oxoaerothionin (149) 
<smiles>[R]Oc1c(Br)cc(CCN(C)C)cc1Br</smiles>

$131 \mathrm{R}=\mathrm{Me}$ $132 \mathrm{R}=\mathrm{H}$<smiles>CC(C)(C)CNC(=O)C1=NO[C@]2(C=C(Br)C(=O)[C@H](Br)[C@@H]2O)C1</smiles><smiles>CC1=C[C@@]2(CC(CCl)=NO2)[C@H](O)[C@@H](Br)C1=O</smiles><smiles>CC(CNC(=O)C1=NO[C@]2(C=C(Br)C(=O)[C@H](Br)[C@@H]2O)C1)C(=O)NCCC(O)C1=NO[C@]2(C=C(Br)C(=O)[C@H](Br)[C@@H]2O)C1</smiles><smiles>C[As](C)(=O)CCCNC(=O)C1=NO[C@]2(C=C(Br)C(=O)[C@H](Br)[C@@H]2O)C1</smiles><smiles>COC1=C(Br)[C@@H](O)[C@@]2(C=C1Br)CC(C(=O)NCCCC(O)CNC(=O)C1=NO[C@]3(C=C(Br)C(OC)=C(Br)[C@@H]3O)C1)=NO2</smiles><smiles>COc1c(Br)cc(CC(C[NH2+])OC)cc1Br</smiles><smiles>[R]C(CNC(=O)C1=NO[C@]2(C=C(Br)C(OC)=C(Br)[C@@H]2O)C1)COc1c(Br)cc(C(O)CNC(=O)C2=NO[C@]3(C=C(Br)C(OC)=C(Br)[C@H]3O)C2)cc1Br</smiles><smiles>CCOC1(OC)C(Br)=CC(O)(CC(N)=O)C=C1Br</smiles><smiles>COC1=C(Br)[C@@H]2OC(=O)C[C@]2(O)C=C1Br</smiles><smiles>CCOC(=O)C1=NO[C@]2(C=C(Br)C(OC)=C(Br)[C@@H]2O)C1</smiles><smiles>C[Mg]</smiles>

Figure 17. Structures of 2-(3,5-dibromo-4-methoxyphenyl)- $N, N, N$-dimethylethanammonium (131), 2,6-dibromo-4-(2-(trimethylammonium)ethyl)phenol (132), agelocaissarines A1 (133), A2 (134), B1 (135), B2 (136), caissarine C (137), 11-deoxyfistularin-3 (138), 2-(3-amino-2,4-dibromo-6-hydroxyphenyl)acetic acid (139), 3-(3,5-dibromo-4-methoxyphenyl-2-methoxy- $N$-methylpropan-1-ammonium (140), (3',5'-dibromo-4'-ethoxy-1'-hydroxy-4'-methoxycycloexa2',5'-dienyle)acetamide (141), aeroplysinin-2 (142), ethyl of 2,4-dibromo-1-hydroxy-3-methoxy-6-oxa-3-azaspiro[4.5]dec-2,4,8-trieno-8-carboxylate (143) and $\left(R^{*}, S^{*}\right)$-[3,5-dibromo-4-(2-oxo-5-oxazolidinyl)methoxyphenyl]-2-oxazolidinone (144).

and 11-oxo-12-hydroxyaerothionin (150). Aerothionin (151) have been isolated from A. fulva collected at São Sebastião, São Paulo State, while 144, 152, 153 and subereatensin (154) have been isolated from an Arraial do Cabo sample of A. fulva, Rio de Janeiro State. Simultaneously, A. fulva from J Reef, Florida (USA) was investigated and yielded 13, homoaerothionin (155), aerophobin-1 (156), aerophobin-2 (157), aplysinamisin-1 (158), aeroplysinin-1
(159) and 2-(3,5-dibromo-1-hydroxy-4-oxocyclohexa-2,5dienyl)acetamide (160). All samples of A. fulva consistently presented bromotyrosine-derived metabolites. ${ }^{72}$

Investigation of the sponge A. fistularis yielded 14, 131, 142, 149-151, verongidoic acid (12, Figure 2), its methyl esther (161, Figure 18) and 11-ketofistularin-3 (162, Figure 18). Compound 162 inhibited the growth of M. tuberculosis at $16 \mathrm{mg} \mathrm{mL}^{-1} .{ }^{75}$ Bromotyrosine $\mathbf{1 4 9}$ 
was further investigated as an anti-inflammatory agent in the presence of lipopolysaccharide, a component of cellwall that triggers the inflammatory response. The assay showed that 149 supressed $\mathrm{NO}_{2}$ and iNOS (inducible nitric oxide synthase) expression, as well as cytokine and prostaglandin E2, responsible for the proinflammatory and immunoregulatory properties. ${ }^{76}$ Investigation of an Aplysina sp. provided 14, while from A. solangeae compounds 13, 150 and 11,12-hydroxiaerothionin (163, Figure 18) have been isolated. ${ }^{77}$ A distinct investigation on A. fistularis yielded 131, aplysfistularine (164, Figure 18), aplysterol (165, Figure 19) and 24,28-didehydroaplysterol (166, Figure 19). The salt 131 inhibited human DNA topoisomerase II-a at concentration of $100 \mu \mathrm{M} .^{78}$

Investigation of the $\mathrm{MeOH}$ extract of Petromica citrina provided halistanol (167, Figure 19) and halistanol sulfate C (168, Figure 19). ${ }^{79}$ Compounds 167 and 168 presented inhibitory effects on the replication of the Herpes Simplex Virus type 1 (HSV-1, KOSstrain), with $\mathrm{IC}_{50}$ at $5.63 \mu \mathrm{g} \mathrm{mL} \mathrm{L}^{-1}$ (selectivity index $(\mathrm{SI})=2.46$ ) and $6.09 \mu \mathrm{g} \mathrm{mL}^{-1}(\mathrm{SI}=1.95)$, respectively, while the fraction that contained these compounds as the major constituents displayed antiviral activity with $\mathrm{IC}_{50}$ at $2.87 \mu \mathrm{g} \mathrm{mL}^{-1}(\mathrm{SI}=15.33)$, suggesting that the anti-HSV-1 activity of the fraction is possibly related
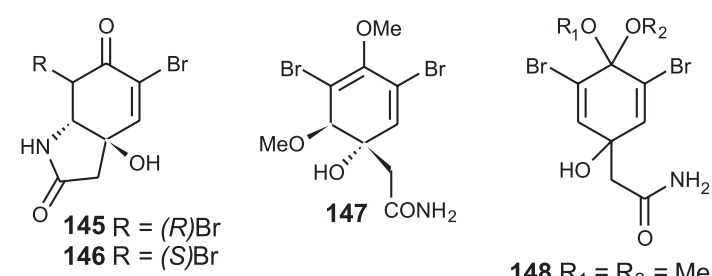

$148 \mathrm{R}_{1}=\mathrm{R}_{2}=\mathrm{Me}$ $153 R_{1}=M e, R_{2}=E t$ to the synergistic effects of compounds 167 and $168 .{ }^{79}$ The known pyrodysinoic acid (169) and three new nitrogen-containing terpenes, isopyrodysinoic acid (170), 13-hydroxyisopyrodysinoic acid (171) and pyrodisinoic acid B (172) have been isolated from Dysidea robusta. ${ }^{80}$

Three novel dissulfated meroterpenoids (Figure 20), ilhabelanol (173), ilhabrene (174) and isoakaterpin (175) have been obtained from the $\mathrm{MeOH}$ extract of Callyspongia sp., and presented a novel carbon skeleton. Isoakaterpin (175) inhibits Leishmania spp. adenine phosphoribosyl transferase with $\mathrm{IC}_{50}$ at $1.05 \mu \mathrm{M}$, which compromises the parasite metabolism. ${ }^{81}$

Halistanol sulfate A (176, Figure 20) was isolated from the $\mathrm{MeOH}$ extract of the sponge Petromica ciocalyptoides. Compound $\mathbf{1 7 6}$ has also been obtained from Topsentia ophiraphidites, first isolated from the marine sponge Halichondria cf. moorei in $1981 .^{69}$ Furodysinin (177, Figure 20) and $9 \alpha, 11 \alpha$-epoxicholest7-en-3 $\beta, 5 \alpha, 6 \alpha, 10$-tetrol-6-acetate (178, Figure 20) have been isolated from Dysidea sp. $^{75}$ Investigation of Ircinia felix $\mathrm{MeOH}$ extract led to the isolation of $4 \mathrm{H}$-pyran-2-ol-acetate (179, Figure 20) as probably an isolation artifact formed by the cyclization of pentanodial by a nucleophilic attack from an acetate anion followed by dehydration and oxidation. ${ }^{58}$<smiles>CCOC(=O)C1=C[C@@H](OC)[C@H]2NC(=O)C[C@]12O</smiles><smiles>COC1=C(Br)C(O)[C@]2(C=C1Br)CC(C(=O)NCCCCCNC(=O)C1=NO[C@]3(C=C(Br)C(OC)=C(Br)[C@H]3O)C1)=NO2</smiles><smiles>COC1=C(Br)C(O)[C@]2(C=C1Br)CC(C(=O)NCCc1cnc[nH]1)=NO2</smiles><smiles>COC1=C(Br)C(O)[C@]2(C=C1Br)CC(C(=O)NCCCc1c[nH]c(N)n1)=NO2</smiles><smiles>COC1=C(Br)C(O)[C@]2(C=C1Br)CC(C(=O)NC/C=C/c1c[nH]c(N)n1)=NO2</smiles><smiles>COC1=C(Br)C(O)[C@](O)(CC#N)C=C1Br</smiles><smiles>NC(=O)CC1(O)C=C(Br)C(=O)C(Br)=C1</smiles><smiles>COC(=O)C1=NO[C@]2(C=C(Br)C(OC)=C(Br)C2O)C1</smiles><smiles>CN(C)CCCOc1c(Br)cc(CCN(C)C)cc1Br</smiles>

Figure 18. Structures of cavernicolins-1 (145) and -2 (146), aplysinafulvin (147), along with the dimethylketal 148, 11-oxoaerothionin (149), 11-oxo12-hydroxyaerothionin (150), aerothionin (151), the phenol 152, the mixed ketal 153, subereatensin (154), homoaerothionin (155), aerophobin-1 (156) aerophobin-2 (157), aplysinamisin-1 (158), aeroplysinin-1 (159), 2-(3,5-dibromo-1-hydroxy-4-oxocyclohexa-2,5-dienyl)acetamide (160), the methyl esther of verongidoic acid (161), 11-ketofistularin-3 (162), 11,12-hydroxiaerothionin (163) and aplysfistularine (164). 


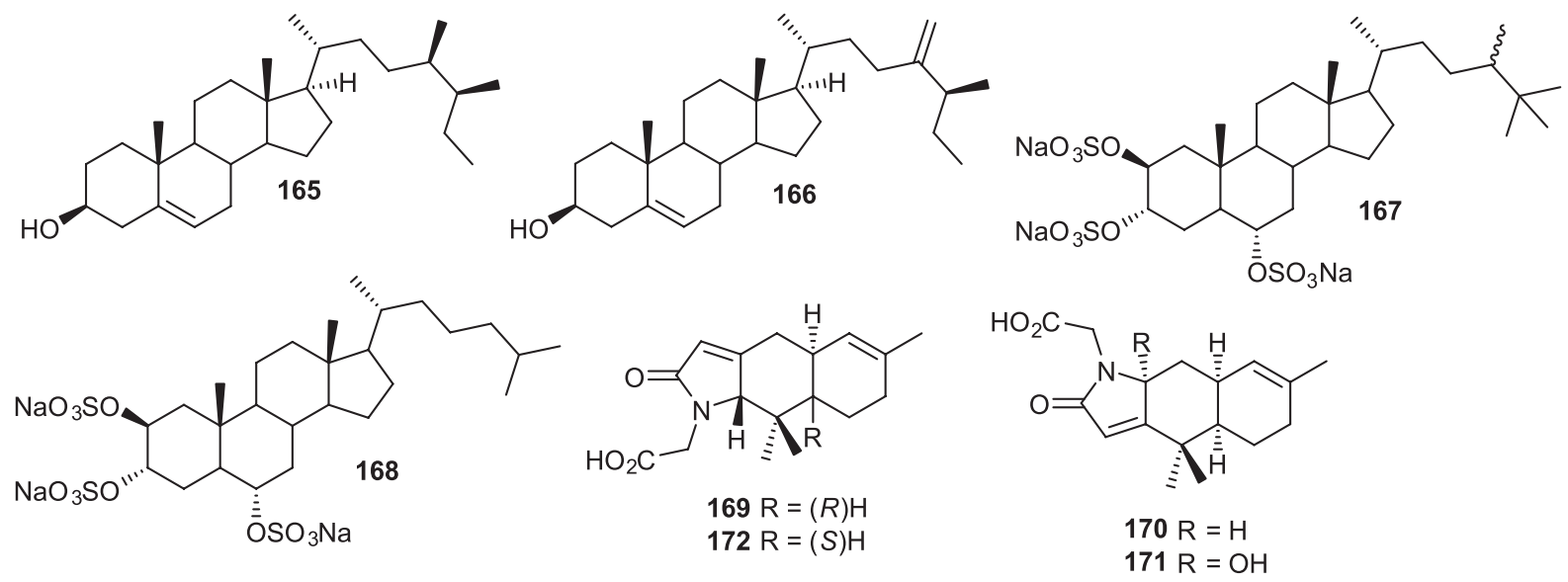

Figure 19. Structures of aplysterol (165), 24,28-didehydroaplysterol (166), halistanol (167), halistanol sulfate C (168), pyrodysinoic acid (169), isopyrodysinoic acid (170), 13-hydroxyisopyrodysinoic acid (171) and pyrodisinoic acid B (172).

A detailed investigation of extracts from the sponge Plakortis angulospiculatus led the isolation of the new plakortenone (180, Figure 21), together with the known plakortin (181, Figure 21), plakortide P (182, Figure 21), (2Z,6R,8R,9E)-methyl 3,6-epoxy-4,6,8-triethyl2,4,9-dodecatrienoate (183, Figure 21), spongosoritin (184, Figure 21) and $(2 E, 6 R, 8 S)$-methyl 3,6-epoxy4,6,8-triethyldodeca-2,4-dienoate (185, Figure 21). Compound 182 presented a potent antiparasitic activity against Leishmania chagasi and Trypanosoma cruzi. ${ }^{82}$

Futher investigations on $P$. angulospiculatus provided (Figure 22) the new 7,8-dihydroplakortide E (186), a diastereoisomer of plakortide $\mathrm{H}(\mathbf{1 8 7})$ and $\mathbf{1 8 8}$, together with seven known polyketides, 6-desmethyl6-ethyl-spongosoritin A (189), 6-desmethyl-6-ethyl9,10-dihydrospongosoritin A (190), spongosoritin A (191), 9,10-dihydrospongosoritin A (192), 193, 194 and plakortide $\mathrm{P}(\mathbf{1 8 2})$. Compounds 182, 187, 189, 190 and 193 presented cytotoxic activity agains HCT-116, PC-3M and MRC-5 cell lineages with $\mathrm{IC}_{50}$ between $0.2-10 \mu \mathrm{M}$, while $\mathbf{1 8 9}$ and 190 induce $a \mathrm{G}_{0} / \mathrm{G}_{1}$ arrest, compounds 182,187 and 193 delivered $\mathrm{G}_{2} / \mathrm{M}$ arrest and accumulation of mitotic figures without affecting the microtubules. ${ }^{83}$

The extracts obtained from the sponge Darwinella cf. oxeata yielded four new rearranged diterpenoids (Figure 23), oxeatine (195) and oxeatamides H-J (196198), along with the known metabolites oxeatamide A (199), the methyl ester of oxeatamide A (200), and membranolide (201). Compound 195 has a new heterocyclic skeleton and $\mathbf{1 9 8}$ have an $N$-methyl urea group included in a $\gamma$-lactam moiety. Compounds 197 and 201 were detected by UPLC-qTOF (ultra-performance

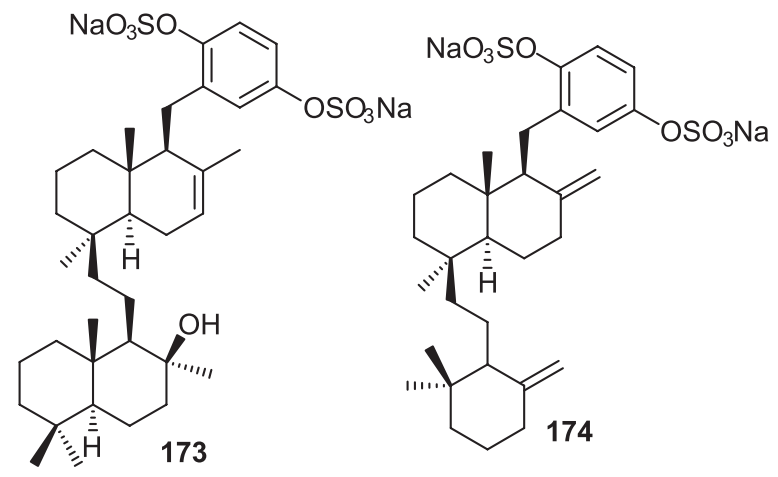<smiles>CC1=CC2CC3(O)OC(=O)C=C3[C@@H](C)[C@H]2CC1</smiles>

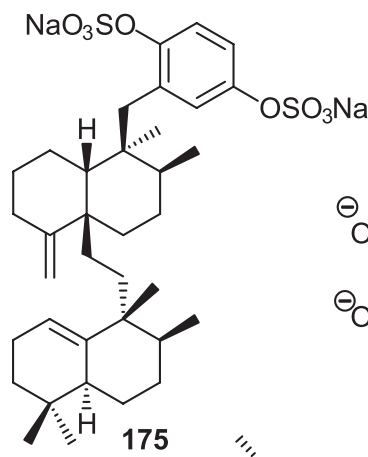

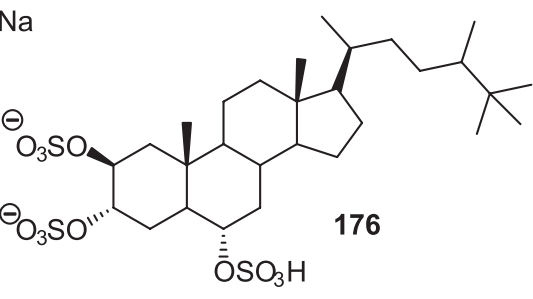

175

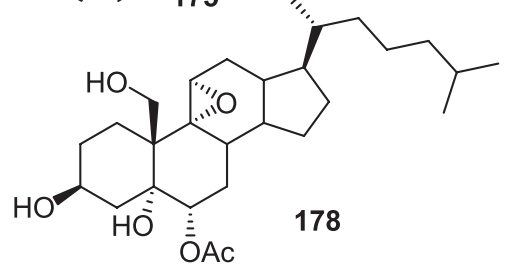<smiles>CC(=O)OC1=CCC=CO1</smiles>

Figure 20. Structures of ilhabelanol (173), ilhabrene (174), isoakaterpin (175), halistanol sulfate A (176), furodysinin (177), $9 \alpha, 11 \alpha$-epoxicholest-7-en$3 \beta, 5 \alpha, 6 \alpha, 10$-tetrol-6-acetate (178) and of 4H-pyran-2-ol-acetate (179). 
<smiles>CCC(/C=C/C(C)=O)C[C@@H]1C[C@H](CC)[C@@H](CC(=O)O)OO1</smiles><smiles>CC/C=C/C(CC)C[C@H]1CC(CC)[C@@H](CC(=O)O)OO1</smiles><smiles>CC/C=C/C(CC)C/C(=C/C1(CC)C[C@H](CC)[C@H](CC(=O)O)OO1)CC</smiles><smiles>[R]C1(CC(C=CCC)CC)C=C(CC)C(=CC(=O)OC)O1</smiles>

Figure 21. Structures of plakortenone (180), plakortin (181), plakortide $\mathrm{P}(\mathbf{1 8 2}),(2 Z, 6 R, 8 R, 9 E)$-methyl 3,6-epoxy-4,6,8-triethyl-2,4,9-dodecatrienoate (183), spongosoritin (184) and (2E,6R,8S)-methyl 3,6-epoxy-4,6,8-triethyldodeca-2,4-dienoate (185).<smiles>CC/C=C/C(CC)CC(CC)CC1(CC)C[C@@](/C=C/C(=O)O)(CC)OO1</smiles>
186<smiles>CC/C=C/C(CC)C/C(C)=C/C1(CC)C[C@H](CC)[C@@H](CC(=O)O)OO1</smiles>

187<smiles>CCCCC(CC)CC1=CC(CC)(C[C@H](CC)[C@@H](CC(=O)O)O[18OH])CC1</smiles>

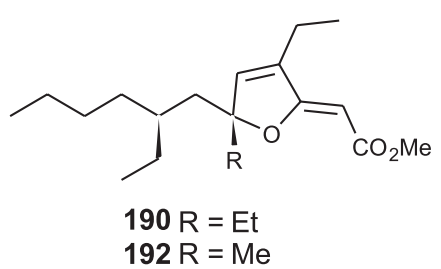<smiles>CCCCC(CC)CC(C)CC1(CC)C=C(CC)[C@@H](CC(=O)O)OO1</smiles>

194 193

Figure 22. Structures of 7,8-dihydroplakortide E (186), a diastereoisomer of plakortide H (187), polyketide 188, 6-desmethyl-6-ethyl-spongosoritin A (189), 6-desmethyl-6-ethyl-9,10-dihydrospongosoritin A (190), spongosoritin A (191), 9,10-dihydrospongosoritin A (192), and of polyketides 193 and 194.

liquid chromatography-quadrupole/time of flight mass spectrometry) analysis in the mantle of the nudibranch Felimida grahami, a predator of D. oxeata. ${ }^{84}$

\subsection{Corals}

The steroid 18-acetoxypregna-1,4,20-trien-3-one (202, Figure 24) has been isolated from the octocoral Carijoa riisei and displayed weak cytotoxic activity against the cell lines SF295 (brain), MDA-MD435 (breast), HCT-8 (colon) and HL60 (leukemia) with $\mathrm{IC}_{50}$ at 14.4, 23.1, 22.0 and $12.4 \mu \mathrm{g} \mathrm{mL}^{-1}$, respectively. ${ }^{69}$ The new hemiketal steroid 23-keto-cladiellin A (203, Figure 24) was isolated from the soft coral Chromonephthea braziliensis. Compound 203 presented antifeeding activity against several species of fishes, properties that justifies the success of the invasion by this exotic octocoral in the Brazilian coast. ${ }^{85} \mathrm{~A}$ new series of sterols (Figure 24) named punicinols A (204), B (205), C (206), D (207) and E (208), has been isolated from the gorgonian Leptogorgia punicea. Compounds 204-208 presented cytotoxic activity against A549 lung cancer cell lineage at 9.6, 9.7, 35.9, 73.3 and $35.8 \mu \mathrm{M}$, respectively. The potent cytotoxic activity of $\mathbf{2 0 4}$ and $\mathbf{2 0 5}$ has been assigned to the absence of the double bond at the side chain. ${ }^{86}$

Chemical investigation of the gorgonian Pseudopterogorgia rigida yielded perezone (209, Figure 25), triacetyl perezone (210, Figure 25) and the epimeric mixture of 2-((2R)-5-hydroxy-6-methylhept-6-en-2-yl)5-methylbenzenene-1,4-diol (211 and 212, Figure 25). This group of quinoidal structures presented cytotoxic activity against various cancer cell lineages. Compound 209 was the most active with $\mathrm{IC}_{50}$ at $8.7 \mu \mathrm{M}$ (HL60, leukemia), $17.9 \mu \mathrm{M}$ (HCT-8, colon), 15.4 $\mu \mathrm{M}$ (SF295, brain), $22.0 \mu \mathrm{M}$ (MDA-MD435, breast), $13.2 \mu \mathrm{M}$ (MDA-MD231, breast), $25.2 \mu \mathrm{M}$ (MX1, breast), $24.2 \mu \mathrm{M}$ (B16, murine melanoma), $11.5 \mu \mathrm{M}$ (J774 murine macrophage) and $16.3 \mu \mathrm{M}$ (L929, murine fibroblast). ${ }^{87}$ Amphidinolide P (213, Figure 25) and its 3-O-methyl derivative (214, Figure 25) have been isolated 
<smiles>CC(=O)c1ccc(C2(C)CCCC(C)(C)C2)c2c1CN(CC(=O)O)C(=O)[C@H]2C</smiles><smiles>[R]N1Cc2c(ccc(C(C)(C)C)c2C(C)C(=O)O)C1=O</smiles><smiles>[R]OC(=O)CN1Cc2c(ccc(C(C)C(=O)O)c2C(C)C)C1=O</smiles><smiles>CC(=O)C(C(C)=O)c1c(C2(C)CCCC(C)(C)C2)ccc2c1C(=O)OC2</smiles>

Figure 23. Structures of oxeatine (195) and oxeatamides H-J (196-198), oxeatamide A (199), the methyl ester of oxeatamide A (200), and membranolide (201).<smiles>C=CC1CCC2C3CCC4=CC(=O)C=CC4(C)C3CCC12COC(C)=O</smiles>

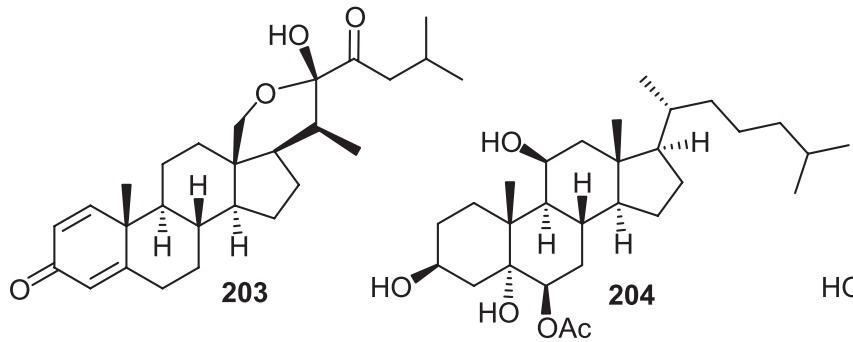<smiles>CC(C)CCC[C@H](C)[C@H]1CC[C@H]2[C@@H]3C[C@H](O)[C@]4(O)C[C@@H](O)CC[C@]4(C)[C@H]3CC[C@]21CO</smiles>

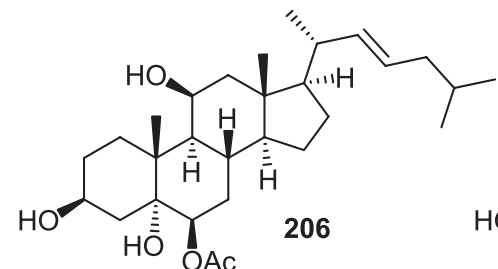

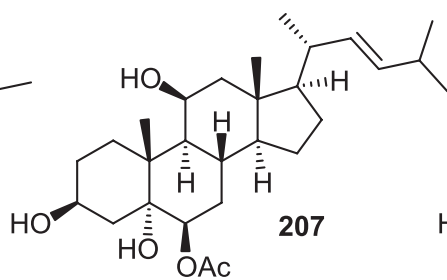<smiles>CC(C)C/C=C/[C@H](C)[C@H]1CC[C@H]2[C@@H]3C[C@H](O)[C@@]4(O)C[C@@H](O)CC[C@]4(C)[C@H]3CC[C@]21CO</smiles>

Figure 24. Structures of 18-acetoxypregna-1,4,20-trien-3-one (202), 23-keto-cladiellin A (203), punicinols A (204), B (205), C (206), D (207) and E (208).<smiles>CC(C)=CCC[C@H](C)C1=C(O)C(=O)C(C)=CC1=O</smiles><smiles>CC(=O)Oc1cc(C)c(OC(C)=O)c(OC(C)=O)c1[C@H](C)CCC=C(C)C</smiles><smiles>[R]C(CC[C@@H](C)c1cc(O)c(C)cc1O)C(=O)O</smiles>

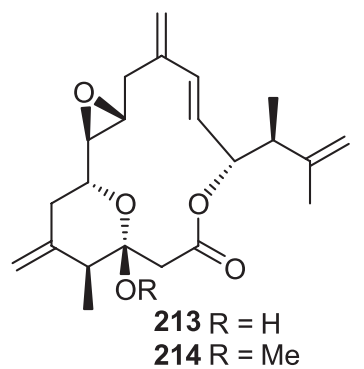

Figure 25. Structures of perezone (209), triacetyl perezone (210) of the epimeric mixture of 2-((2R)-5-hydroxy-6-methylhept-6-en-2-yl)-5-methylbenzenene1,4-diol (211 and 212), amphidinolide P (213) and its 3-O-methyl derivative (214).

from the octocoral Stragulum bicolor. Compound 214 is probably an artifact of isolation. ${ }^{88}$

\subsection{Bryozoans}

Investigation of the $\mathrm{MeOH}$ extract of the bryozoan Bugula dentata led to the isolation of tambjamines A (215, Figure 26), B (216, Figure 26), C (217, Figure 26), D (218, Figure 26), K (219, Figure 26), 5'-bromo-4-methoxy2,2'-pyrrol-5-carboxyaldehyde (220, Figure 26) along with the new tambjamine J1 (221, Figure 26). ${ }^{89}$ The alkaloid 2,5,6-tribromo- $N$-methylgramine (222, Figure 26) has been obtained from the bryozoan Zoobotryon verticillatum (Amathia verticillata). ${ }^{89}$ Re-investigation of extracts obtained from different samples of Amathia verticillata provided the new alkaloid 2,6-dibromo- $N$-methylgramine (223, Figure 26), together with 222..$^{90}$

\subsection{Mollusks}

Very often shell-less marine mollusks accumulate metabolites captured from preys, which can be invertebrates such as sponges, ascidians, bryozoans, soft-corals and other mollusks. Such metabolites are considered as chemical defenses of the soft-bodied, frequently beautifully colored nudibranchs.

The bis-pyrrole alkaloids (Figure 26) tambjamines A (215) and D (217) have been isolated from the nudibranch Tambja 
<smiles></smiles><smiles>[Z10]C1=NC(c2ccc(Br)[nH]2)=CC1=CN</smiles><smiles>COC1=CC(c2ccc[nH]2)=N/C1=C\NCCC(C)C</smiles>
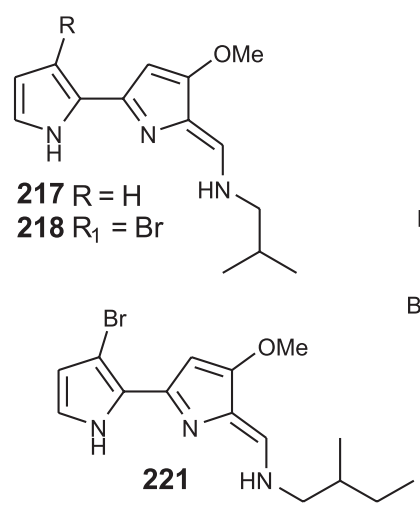

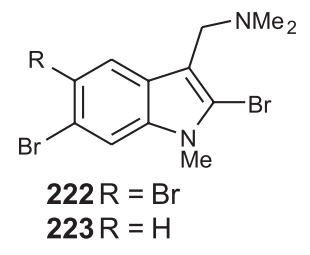

Figure 26. Structures of tambjamines A (215), B (216), C (217), D (218), K (219), 5'-bromo-4-methoxy-2,2'-pyrrol-5-carboxyaldehyde (220), tambjamine $\mathrm{J} 1$ (221), 2,5,6-tribromo- $N$-methylgramine (222) and of 2,6-dibromo- $N$-methylgramine (223).

eliora. Compound 217 displayed cytotoxic activity cells lines CEM (leukemia), HL60 (leukemia), MCF-7 (breast), HCT-8 (colon) and B16 (leukemia) with $\mathrm{IC}_{50}$ at 12.2, 13.2, 13.2, 10.8 and $6.7 \mu \mathrm{g} \mathrm{mL}{ }^{-1}$, respectively. ${ }^{58}$ The nudibranch T. stegosauriformis is the predator of the bryozoan $B$. dentata, and accumulates tambjamine alkaloids (Figure 26) found in tissues of the bryozoan, such as tambjamines C (216) and $\mathrm{K}$ (219). The alkaloid $\mathbf{2 2 3}$ isolated from the bryozoan Zoobotryon verticillatum (Amathia verticillata) has also been isolated from the nudibranch Okenia zoobotryon. Extracts of the nudibranch Hypselodoris lajensis provided the diterpene furodysinin (177, Figure 20), previously isolated only from marine sponges ${ }^{89}$

Extracts of the sea slug Pleurobranchus areolatus yielded the modified diketopiperazines $\mathbf{2 2 4}$ and $\mathbf{2 2 5}$ (Figure 27), as well as, four new modified rodriguesines (Figure 27), rodriguesic acid (226), its hydroxamate (227), and the corresponding methyl esters 228 and 229. ${ }^{91}$ Amphidinolide P (213, Figure 25) has been isolated from the nudibranch Marionia limceana which preys on the coral S. bicolor ${ }^{88}$

\subsection{Ascidians}

Colonial ascidians are members of Tunicata phylum which are the most often investigated towards the discovery of bioactive secondary metabolites. A large number of ascidians natural products are alkaloids and NRPS-derived peptides, some of which are produced by the associated microflora such as Prochloron. ${ }^{92,93}$

From the ascidian Clavelina oblonga the new aminoalcohol (2S,3R)-2-aminododecan-3-ol (230, Figure 28) has been isolated together with the known bis-oxazolidinone 144, previously reported only from Verongid sponges. The absolute stereochemistry of $\mathbf{2 3 0}$ was determined after derivatization and circular dichroism analysis. Compound $\mathbf{2 3 0}$ displayed antifungal activity against Candida albicans and C. glabrata with MIC at 0.7 and $30.0 \mu \mathrm{g} \mathrm{mL}^{-1}$, respectively. ${ }^{94}$ The new polyunsaturated alcohol 3Z,6Z,9Z-dodecatrien-1-ol (231, Figure 28) have been obtained from Botrylloides giganteum..$^{58}$

Investigation of the extract from Didemnum ligulum yielded asterubin (232, Figure 28) and $N, N$-dimethyl$O$-methylethanolamine (233, Figure 28) ${ }^{69}$ Extracts of the ascidian Didemnum sp. provided the highly modified diketopiperazines (Figure 28) rodriguesine A (224) and B (225). Rodriguesines $N$-acetyl derivatives 234 and 235, respectively, have been obtained from another sample of the same ascidian collected at the same location. ${ }^{95}$ Structure of compounds 224, 225, 234 and 235 has been established by analysis of spectroscopic data, while absolute configuration has been established by Marfey's method.

Investigation of an aqueous $\mathrm{MeOH}$ extract of the ascidian Eudistoma vannamei yielded two new<smiles>CCCCCCCCC[C@H](CC(=O)NCCN)N1CC(=O)N[C@H](Cc2ccccc2)C1=O</smiles>

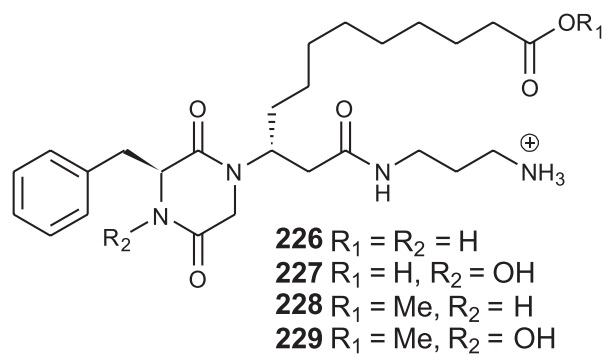

Figure 27. Structures of rodriguesines A (224) and B (225), rodriguesic acid (226), its hydroxamate (227), and of the corresponding methyl esters 228 and 229. 
<smiles>CCCCCCCCCC(O)C(C)N</smiles><smiles>CCC=CCC=CCC=CCCO</smiles>

231<smiles>CNC(=N)NCCCOCCO</smiles>
232<smiles>COCCN(C)C</smiles>

233<smiles>CCCCCCCCC[C@H](CC(=O)NCCNC(C)=O)N1CC(=O)N[C@@H](Cc2ccccc2)C1=O</smiles>

Figure 28. Structures of (2S,3R)-2-aminododecan-3-ol (230), 3Z,6Z,9Z-dodecatrien-1-ol (231), asterubin (232), $N, N$-dimethyl- $O$-methylethanolamine (233), and of rodriguesines $N$-acetyl derivatives 234 and 235 .

staurosporine derivatives, 2-hydroxy-7-oxostaurosporine (236, Figure 29) and 3-hydroxy-7-oxostaurosporine (237, Figure 29). The mixture of $\mathbf{2 3 6}$ and $\mathbf{2 3 7}$ displayed cytotoxic activity across a panel of tumor cell lines with $\mathrm{IC}_{50}$ values in the range of 10.3-144.47 $\mathrm{nM}$ and was 14 times more cytotoxic than staurosporine (238).$^{96}$ The occurrence of such alkaloids in E. vannamei may be correlated to the presence of associated biota, such as Streptomyces bacteria. In the light of to this hypothesis, marine microorganisms associated with E. vannamei were recovered and cultured. One strain of Streptomyces sp. was able to generate staurosporine (238), detected by LC-MS/MS analysis, while none of the hydroxy-7-oxo derivatives were detected. ${ }^{97}$

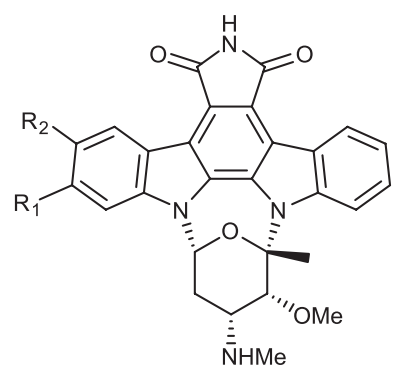

$236 \mathrm{R}_{1}=\mathrm{OH}, \mathrm{R}_{2}=\mathrm{H}$

$237 \mathrm{R}_{1}=\mathrm{H}, \mathrm{R}_{2}=\mathrm{OH}$

Figure 29. Structures of 2-hydroxy-7-oxostaurosporine (236), 3-hydroxy7-oxostaurosporine (247) and of staurosporine (238).

\section{Total Synthesis of Marine Natural Products in Brazil}

In the first and sole review on the synthesis of marine metabolites by Brazilian organic synthesis chemists, Prof Alphonse Kelecom reviewed the synthesis of twenty-three metabolites, the large majority being terpenes. ${ }^{98}$ Synthesis of alkaloids and polyketides have also been included. The present coverage attempts to comprehensively update Prof Kelecom's review, organized by biological source and biogenetic grounds. Only total syntheses of natural products have been herein considered, including syntheses that enabled structural re-assignments of natural products. Partial syntheses, formal syntheses, syntheses of "unnatural" natural products and of natural product derivatives are explicitly omitted.

\subsection{Total synthesis of marine microbe metabolites}

The antibiotic pentabromopseudilin (239) is considered the first secondary metabolite isolated from cultures of a marine bacterium, namely Pseudomonas bromoutilis $^{99}$ and Chromobacterium sp. ${ }^{100}$ Schwalm et al. ${ }^{101}$ synthesis of 239 (Scheme 4) proceeded from the orthomethoxy benzenediazonium salt $\mathbf{2 4 0}$ converted into the 2 -arylpyrroline $\mathbf{2 4 1}$ in $\mathbf{7 8 \%}$ yield after optimization. The product $\mathbf{2 4 1}$ was converted into the 2 -substituted protected pyrrole 242 by oxidation with DDQ in almost quantitative yield. Deprotection of both pyrrole and phenol groups to give $\mathbf{2 4 3}$ was accomplished in excellent yields, followed by bromination with pyridine/ $\mathrm{HBr}$ to give the natural product 239 in $28 \%$ overall yield.

Enhygrolide A (244) was isolated from cultures of the marine myxobacterium Enhygromyxa salina, and displayed antibiotic activity against Arthrobacter crystallopoietes. ${ }^{102}$ The synthesis of 244 (Scheme 5) ${ }^{103}$ was accomplished from the condensation of tetronic acid 245 with paramethoxybenzaldehyde (246) using Hantzch ester $\mathbf{2 4 7}$ as hydride source and $L$-proline as catalyst. Esterification of the product $\mathbf{2 4 8}$ with pivaloyl chloride under basic conditions provided 249 which underwent alkylation with isobutyl magnesium bromide to give 250. Condensation with benzaldehyde followed by phenol deprotection gave enhygrolide A (244) in 54\% overall yield.

The total synthesis of coibacins A (251) and B (252) have been completed and allowed the revision of the stereochemistry (Scheme 6). ${ }^{104}$ Coibacins were first isolated from the cyanobacterium Oscillatoria sp. and displayed cytotoxic and anti-Leishmanial activity. ${ }^{105}$ The highly convergent strategy involved the preparation of four 

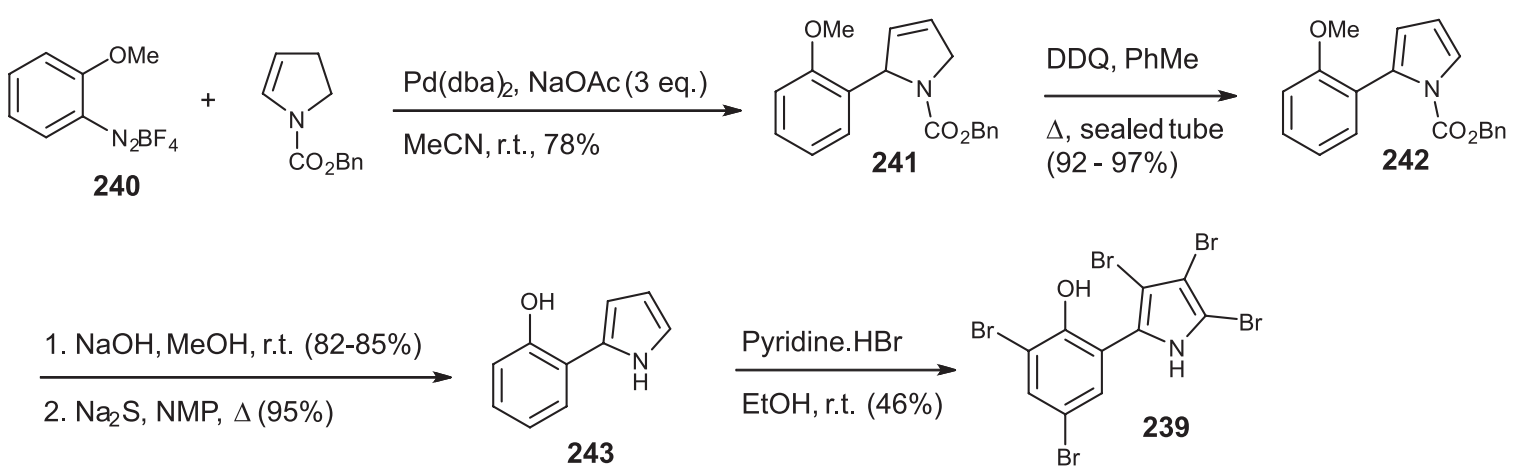

Scheme 4. Total synthesis of pentabromopseudilin (139). ${ }^{101}$

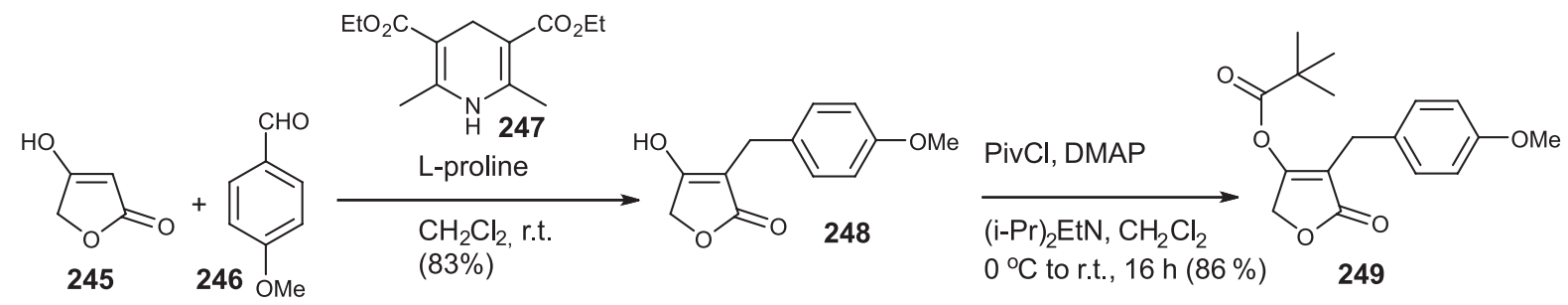

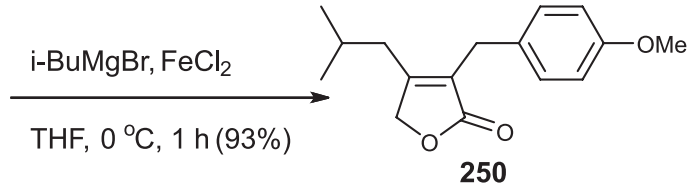

Scheme 5. Total synthesis of enhygrolide A (244). ${ }^{102}$

intermediates, 257, 263, 265 and 269. The preparation of ketal 257 started by protection of the epoxyalcohol $\mathbf{2 5 3}$, followed by esterification of alcohol $\mathbf{2 5 4}$ and metatesis reaction with Grubbs I catalyst, to afford the lactone $\mathbf{2 5 5}$ in $58 \%$ yield over four steps. Reduction with DIBALH and formation of the ketal group was followed by the alcohol deprotection and oxidation to give the chiral ketal 257 in $72 \%$ over four additional steps. The synthesis of phosphonium salt $\mathbf{2 6 3}$ was achieved from the diol $\mathbf{2 5 8}$ via two tandem oxidation/Wittig olefinations, followed by the diester $\mathbf{2 6 0}$ reduction and monoprotection. The phosphonium salt $\mathbf{2 6 3}$ was then prepared by usual interconversions. The overall yield for the preparation of $\mathbf{2 6 3}$ from $\mathbf{2 5 8}$ was $32 \%$. Coupling of $\mathbf{2 5 7}$ with $\mathbf{2 6 3}$, followed by the alcohol deprotection and oxidation to the corresponding aldehyde gave $\mathbf{2 6 5}$ in $\mathbf{6 0 \%}$ over two steps. Next, preparation of the cyclopropane moiety involved a Charette asymmetric cyclopropanation of trans-crotyl alcohol (266) using a borolane-based ligand. The product 267 was reacted with 2-mercaptobenzothiazole in the presence of diisopropyl azodicarboxylate to give $\mathbf{2 6 8}$ in a Mitsunobu-type reaction. Oxidation of the mercaptane 268 with ammonium molybdate and oxygen peroxide yielded the suitable sulfone $\mathbf{2 6 9}$ in $39 \%$ over three steps. Coupling aldehyde 265 with the sulfone $\mathbf{2 6 9}$ was achieved in the presence of sodium hexamethyldisilazide. The product $\mathbf{2 7 0}$ was subjected to oxidation with pyridinium chlorocromate to afford a mixture of geometric isomers resulting from the Wittig reactions, which could be efficiently separated by HPLC. Analysis of the products obtained indicated that $(5 S, 16 R, 18 R)-\mathbf{2 5 1}$ was the enantiomer of natural coibacin A, which had, then, its stereochemistry redefined. The synthetic strategy developed for the synthesis of coibacin A enabled the preparation of all its stereoisomers. Coibacin B (252) was prepared by a very similar approach to that of coibacin A (251).

The total synthesis of lyngbyabellin M (271), ${ }^{106}$ a metabolite isolated from the cyanobacterium Moorea bouilloni, ${ }^{107}$ has been achieved using a highly convergent approach (Scheme 7). The first fragment 274 was prepared from $(S)$-1-ethoxy-1-oxobutan-2-aminium chloride (272) and (R)-2,2-dimethyl-1,3-dioxolane4-carbaldehyde (273) in a three-step reaction sequence. The second fragment 280 was synthezised from $L$-valine (275), 
starting by the preparation of the thioamide 276 which was coupled with ethyl 3-bromo-2-oxopropanoate (277) in the presence of 2-ethyloxirane (278). The product 279 was deacetylated with dibutyltin oxide to give the thiazole $\mathbf{2 8 0}$.

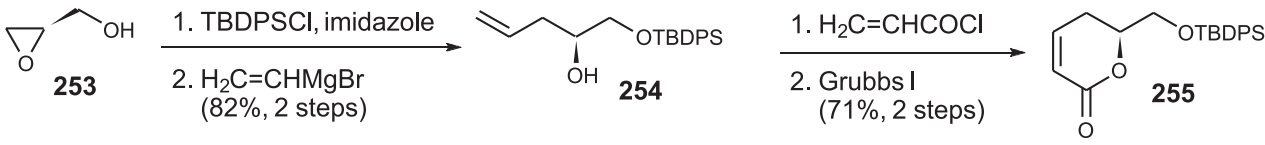

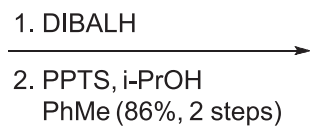

$$
\begin{aligned}
& \overbrace{}^{256} \\
& \begin{array}{c}
\text { 2. } \begin{array}{c}
\text { Swern } \\
(83 \%)
\end{array} \\
257
\end{array}
\end{aligned}
$$
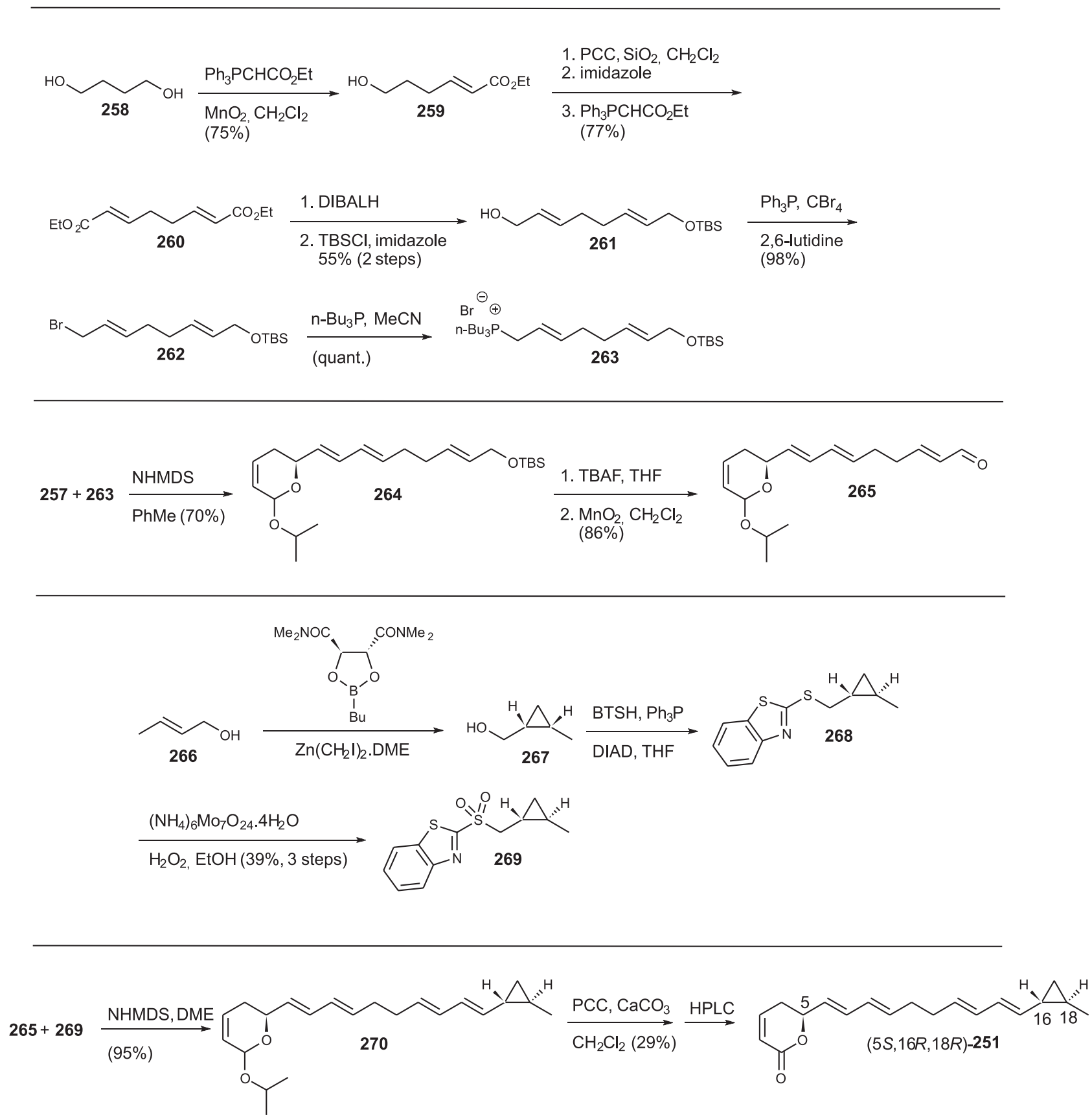

Scheme 6. Total synthesis of coibacin A $[(5 S, 16 R, 18 R)-251] .{ }^{104}$ 
The preparation of 5,5-dichlorohexanal (284) involved the conversion of hex-5-en-2-one (281) to its corresponding hydrazone followed by oxidation in the presence of copper chloride to give $\mathbf{2 8 2}$. Hydroboration-oxidation followed by oxidation of the alcohol $\mathbf{2 8 3}$ gave $\mathbf{2 8 4}$. Reaction of $\mathbf{2 8 4}$ with the chiral propionate ester $\mathbf{2 8 5}$ provided the ester $\mathbf{2 8 6}$ which was hydrolysed to $\mathbf{2 8 7}$. The absolute configuration of $\mathbf{2 8 7}$ was confirmed by its conversion to the corresponding diol (by reduction of the acid with $\mathrm{LiAlH}_{4}$ ), followed by conversion to the corresponding acetonide with 2,2-dimethoxypropane
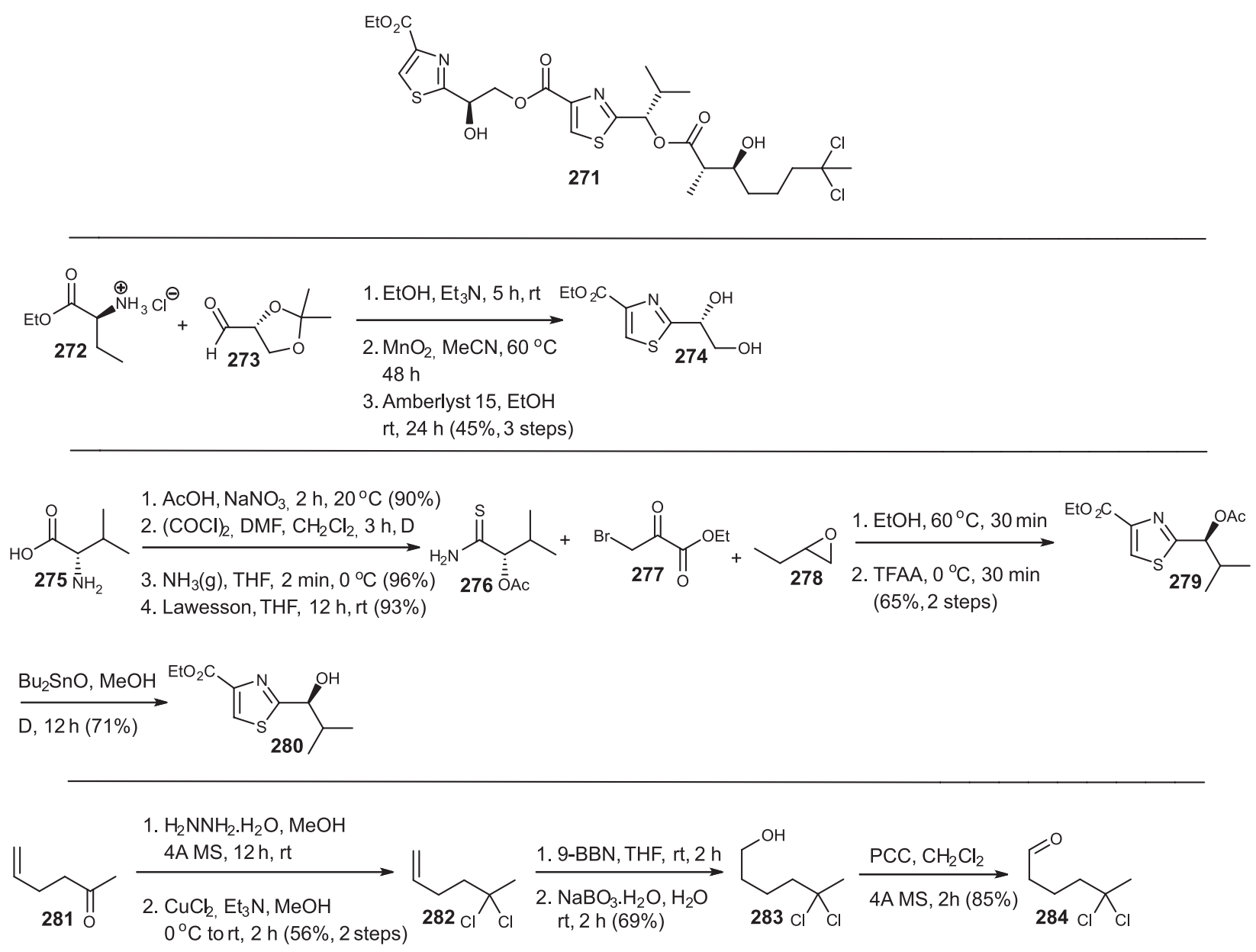

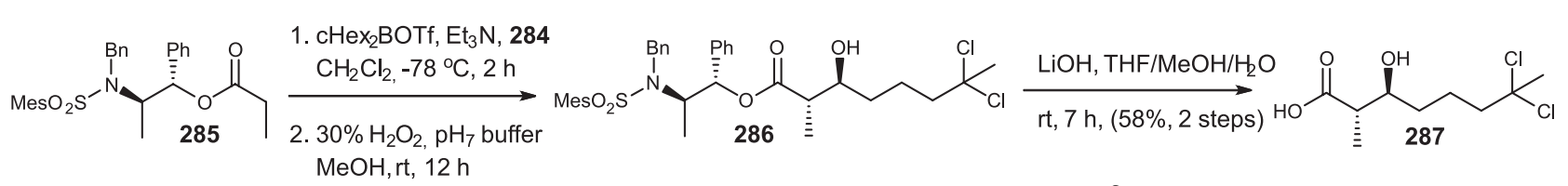

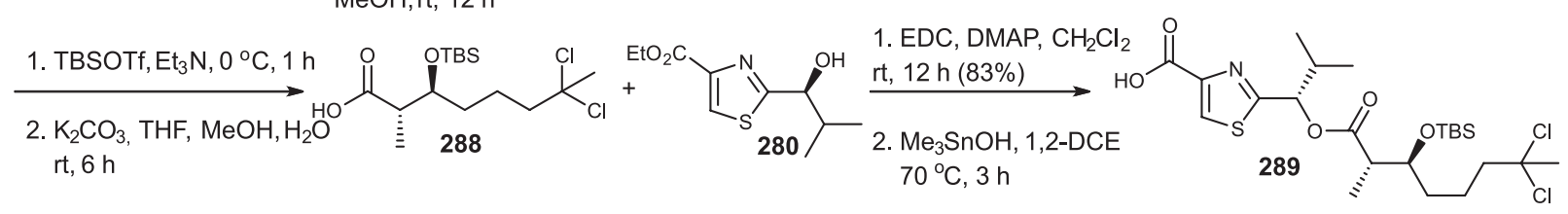

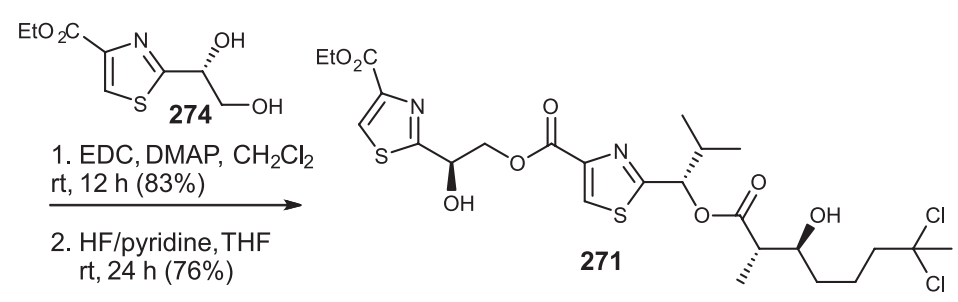

Scheme 7. Total synthesis of lyngbyabellin M (271). ${ }^{106}$ 
with concomitant Mosher ester analysis. After the alcohol protection of $\mathbf{2 8 7}$, the product was coupled with $\mathbf{2 8 0}$ in the presence of 1-ethyl-3-(3-dimethylaminopropyl)carbodiimide (EDC) and DMAP, followed by ethyl ester hydrolysis with hydroxymethyltin to provide $\mathbf{2 8 9}$. Intermediate $\mathbf{2 8 9}$ was coupled with 274 also using EDC and DMAP, followed by the alcohol deprotection, to give lyngbyabellin M (271). Although the spectroscopic data of both synthetic and natural 271 compared almost exactly, the specific rotation of synthetic $271\left\{[\alpha]_{\mathrm{D}}{ }^{25}+12(c 0.5, \mathrm{MeOH})\right\}$ had an opposite signal relatively to the natural product, $[\alpha]_{\mathrm{D}}^{25}-4.5(c 0.5$, $\mathrm{MeOH})$.

\subsection{Total synthesis of metabolites from marine invertebrates}

\subsubsection{Marine sponges}

\subsubsection{Alkaloids}

The brominated alkaloids 3-bromoverongiaquinol (290) and 5-monobromocavernicolin (291), previously isolated from the sponge Aplysina cavernicola, ${ }^{108}$ have been synthezised (Scheme 8). ${ }^{109}$ Starting from para-benzoquinone (292), which reacted with the lithium enolate of $\mathrm{N}, \mathrm{O}$-bistrimethylsilylacetamide (293) to give the mixture of protected and unprotected amides 294 and 295. The mixture of 294 and 295 were first brominated then treated with 1,8-diazabicyclo[5.4.0]undec-7-ene (DBU) in MeCN to provide 290 and 291 in 47 and 20\% yield, respectively.

The synthesis of the alkaloid (+)-trans-trikentrin A (296), isolated from the sponge Trikentrion flabelliforme, ${ }^{110}$ has been accomplished (Scheme 9). ${ }^{111}$ 7-Bromo-4-ethyl$1 \mathrm{H}$-indole (297) was first protected and then subjected to a Heck coupling with methyl crotonate to give $\mathbf{2 9 8}$, which was reduced at the double bond and de-racemized using a lipase hydrolyis with Amano OS-CII enzyme, a formulation of Pseudomonas cepacia lipase immobilized on a ceramic substrate, to give 299. This intermediate was subjected to a Kowalski homologation towards 300, which was then cyclized using a Friedel-Crafts like acylation, to provide 301. After indole nitrogen re-protection with Boc, the ketone was reduced and dehydrated to prepare the substrate $\mathbf{3 0 2}$ for a ring contraction with thallium trinitrate trihydrate and $\mathrm{NaBH}_{4}$. The product $\mathbf{3 0 3}$ was detosylated and<smiles>COC(C)=NN(C)C(=O)OC(C)=O</smiles>

295: $R=$ TMS $(18 \%)$

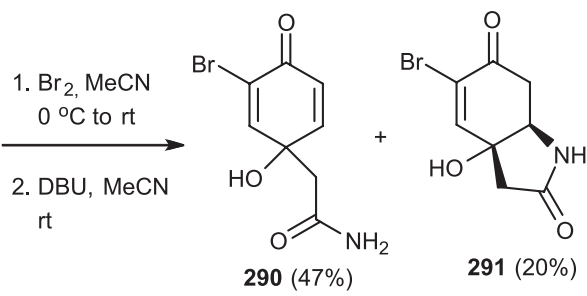

Scheme 8. Syntheses of 3-bromoverongiaquinol (290) and 5-monobromocavernicolin (291). ${ }^{109}$<smiles>CCc1ccc(Br)c2[nH]ccc12</smiles>
297
1. $\mathrm{KOH}, \mathrm{BnBr}$, DMSO

2. methyl crotonate, $\mathrm{PdCl}_{2}$ $\mathrm{P}(\mathrm{o}-\mathrm{tol})_{3}, \mathrm{Et}_{3} \mathrm{~N}, \mathrm{MeCN}$ ( $74 \%, 2$ steps)

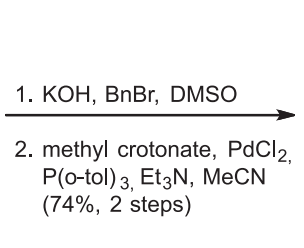

$\underbrace{(1)}_{298}$
1. $\mathrm{Mg}, \mathrm{MeOH}$

2. kinetic resolution

(n)<smiles>[R]NC(=O)CC1(O)C=CC(=O)C=C1</smiles>

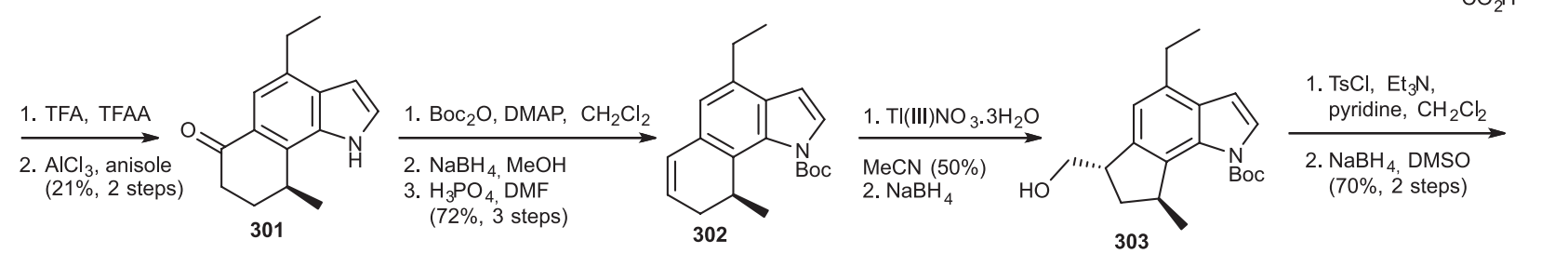<smiles>CCc1cc2c(c3[nH]ccc13)[C@H](C)C[C@H]2C</smiles><smiles>CCc1ccc([C@@H](C)CC(C)=O)c2[nH]ccc12</smiles>

1. $\mathrm{BH}_{3}-\mathrm{SMe}_{2} \mathrm{MeOH}, \mathrm{Et}_{2} \mathrm{O}$

2. $\mathrm{MsCl}$, DMAP, pyridine, $\mathrm{CH}_{2} \mathrm{Cl}_{2}$

3. KCN, DMSO

4. $\mathrm{KOH}$, ethylene glycol, $\mathrm{H}_{2} \mathrm{O}$

( $73 \%, 4$ steps)

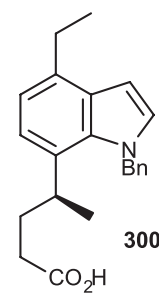

Scheme 9. Synthesis of (+)-trans-trikentrin A (296). ${ }^{11}$ 
$\mathrm{N}$-deprotected to afford the natural product 296 in $70 \%$ over two steps. The natural product (+)-trans-triketrin A (296) displayed very good cytotoxic activity on breast (MCF-7), ovarian resistant (NCI-ADR/RES), ovarian (OVCAR-3) and prostate (PC-3) cancer cell lines, with $\mathrm{IC}_{50}$ at $2.8,2.5$, 3.1 and $6.6 \mathrm{mg} \mathrm{mL}^{-1}$, respectively.

The pyrimidine alkaloid monalidine (121), isolated form the sponge Monanchora arbuscula,${ }^{71}$ has been synthezised in four steps (Scheme 10), ${ }^{71}$ starting with a base-catalyzed Claisen condensation between undecan-2-one (304) and dihydrofuran-2(3H)-one (305). The product obtained (306) was condensed with guanidine hydrochloride (307) in the presence of potassium tert-butoxide, to give the pyrimidine 308. Reaction of 308 under Mitsonobu-like conditions provided the alkaloid $\mathbf{1 2 1}$ identical to the natural product. ${ }^{71}$

\subsubsection{Aromatic derivatives}

A convergent synthesis of metachromin A (309), previously isolated from the sponge Hippospongia metachromia, ${ }^{112}$ has been completed (Scheme 11). ${ }^{113}$ Synthesis of the non-aromatic fragment $\mathbf{3 1 0}$ started by alkylation of the trimethylsilylenol ether derived from 2,6-dimethylcyclohexanone (311) with methyl vinyl ketone (312). The product (313) was protected with 2,2-dimethyl1,3-propanediol (314) before a Wittig olefination followed by the ketone deprotection, to give $\mathbf{3 1 0}$. The synthesis of the aromatic moiety $\mathbf{3 1 6}$ started with the transformation of the chloride $\mathbf{3 1 7}$ into the carboxylic acid $\mathbf{3 1 8}$, which was then reduced and protected to give $\mathbf{3 1 9}$. The protected alcohol $\mathbf{3 1 9}$ was then oxidized and acetoxylated to yield $\mathbf{3 2 0}$ before transformation of the protected alcohol in the phosphonate 316. Both 310 and $\mathbf{3 1 6}$ were then coupled via a HornerWadsworth-Emmons reaction, to yield the precursor of the natural product 309, which was obtained after the reduction of esters and oxidation of the hydroquinone.

An inhibitor of the SARS-coronovirus 3CL protease, esculetin-4-carboxylic acid ethyl ester (322) isolated from the sponge Axinella cf. corrugata, ${ }^{114}$ has been synthezised in three steps (Scheme 12). ${ }^{114}$ Baeyer-Villiger oxidation of 3-hydroxy-4-methoxybenzaldehyde (323) was followed by condensation of the formyl ester $\mathbf{3 2 4}$ with the sodium derivative of diethyl oxalacetate (325) to give ethyl scopoletin-4-carboxylate (326), which was transformed into the natural product $\mathbf{3 2 2}$ after removal of the methyl group with boron tribromide. Esculetin-4-carboxylic acid ethyl ester (322) inhibited recombinant $3 \mathrm{CL}^{\text {pro }}$ in vitro with $\mathrm{ID}_{50}$ of $46 \mathrm{mmol} \mathrm{L}^{-1}$. The same compound inhibited SARS$\mathrm{CoV}$ replication in Vero cells with $\mathrm{EC}_{50}$ of $112 \mathrm{mmol} \mathrm{L}^{-1}$, with no cytotoxic activity. ${ }^{114}$

\subsubsection{Polyketides}

A synthesis of callystatin A (327), a potently cytotoxic complex polyketide isolated from the sponge Callyspongia truncata in minute amounts $(1 \mathrm{mg}$ from $100 \mathrm{~kg}$ of sponge), ${ }^{115}$ has been developed (Scheme 13) ${ }^{116}$ in preparing three fragments, 328, 329 and 330, for subsequent coupling. Fragment 328 was synthezised from the chiral diol ester 331 by tert-butylsilyl (TBS)-protection, followed by ester reduction to the corresponding aldehyde, which was condensed with ethyl 2-((bis(o-tolyloxy))phosphoryl) acetate to give the unsaturated ester 332 in a 94:6 Z/E selectivity. The ester was converted to the chiral lactone by treatment with DIBALH for the ester reduction, a Dowex resin for the alcohols deprotection, followed by a $\mathrm{MnO}_{2}$ oxidation to provide the lactone 333. Protection of the primary alcohol with TBS, then reduction of the lactone carbonyl group and treatment of the lactol with i-PrOH and catalytic PPTS provided the desired ketal 328. The second fragment was the phosphonium salt 329, synthezised from methyl (R)-3-hydroxy-2-methylpropanoate (334), first by alcohol protection, then ester reduction followed by a Swern oxidation to provide the aldehyde $\mathbf{3 3 5}$. This aldehyde was coupled with the $\beta$-ketophosphonate $\mathbf{3 3 6}$ to yield the unsaturated ester 337. Ester reduction with DIBALH, followed by alcohol substitution by bromine and subsequent substitution by tributylphosphine provided the suitable phosphonium salt $\mathbf{3 2 9}$. Coupling of $\mathbf{3 2 8}$ and $\mathbf{3 2 9}$ in the presence of ((methylsulfinyl)methyl)lithium gave the conjugated diene $\mathbf{3 3 9}$ in excellent yield (82\%) and with a 95:5 E/Z stereoselectivity. Primary alcohol deprotection followed by functional group interconversions (FGI) to its corresponding iodide $\mathbf{3 4 0}$ was accomplished in $\mathbf{9 0 \%}$

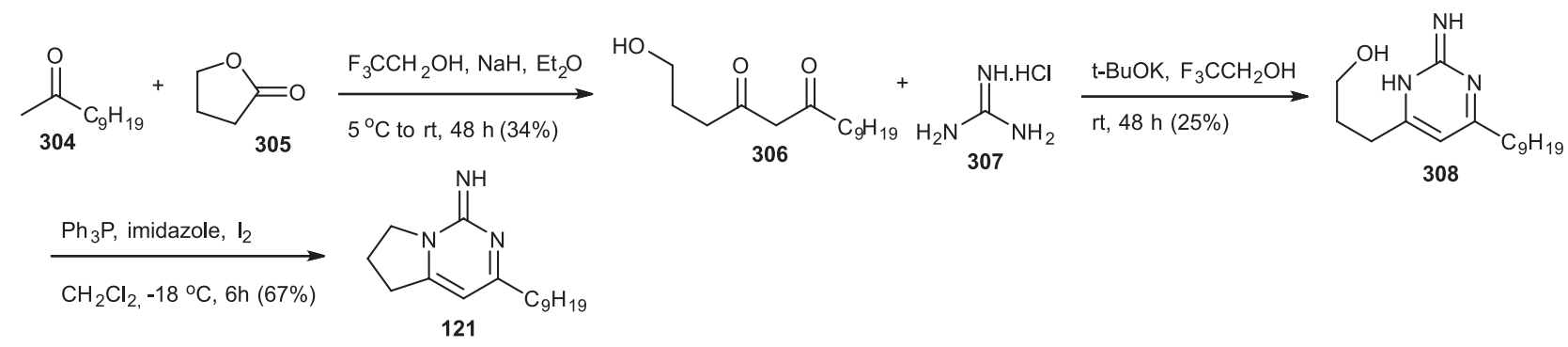

Scheme 10. Total synthesis of monalidine (121) ${ }^{71}$ 

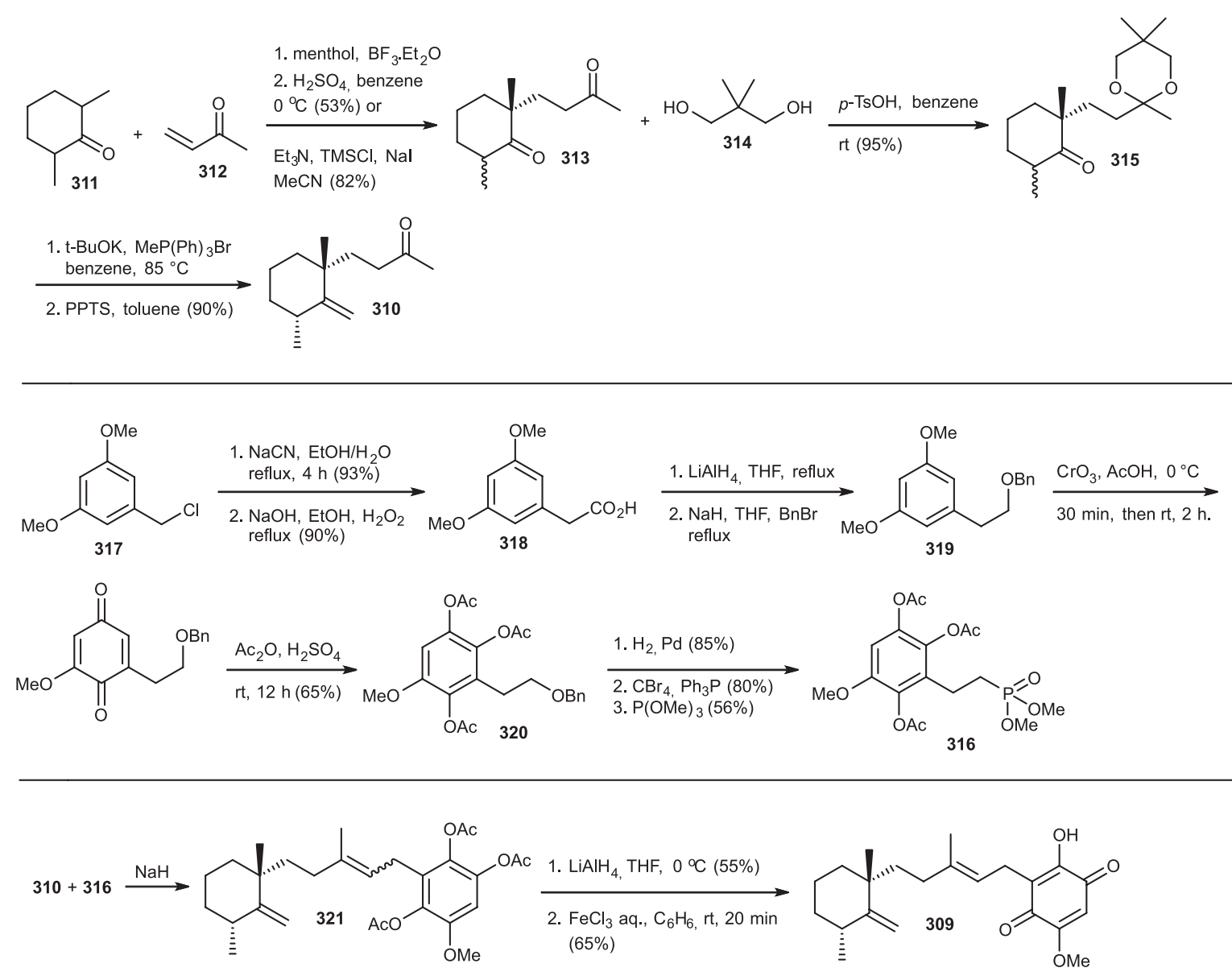

Scheme 11. Total synthesis of synthesis of metachromin A (309). ${ }^{113}$

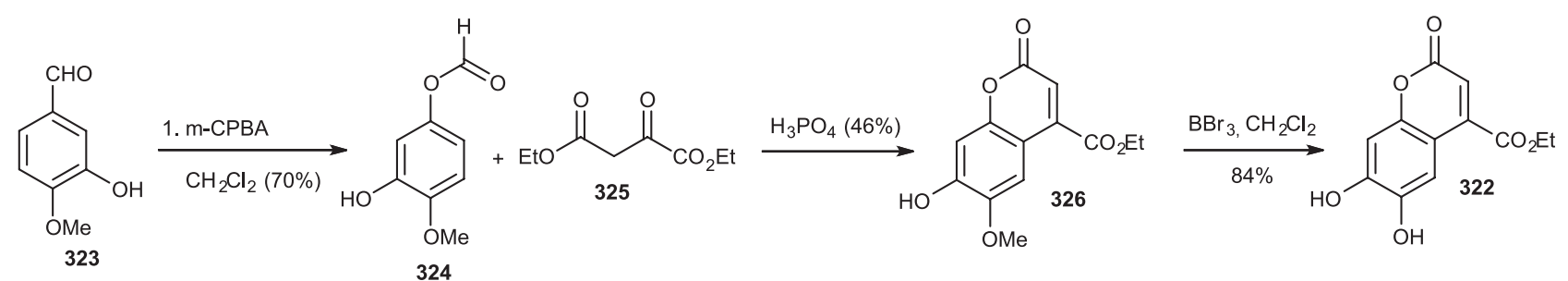

Scheme 12. Total synthesis of esculetin-4-carboxylic acid ethyl ester (322). ${ }^{114}$

yield in two steps. The third fragment $\mathbf{3 3 0}$ was synthezised through the longer sequence, starting by coupling 341 and 342 in 89\% yield and 95:5 diastereoselectivity. Conversion of the oxazolidinone $\mathbf{3 4 3}$ to its corresponding Weinreb's amide and alcohol protection led to $\mathbf{3 4 4}$, which was then converted to the alcohol 345 by amide reduction to its corresponding aldehyde before condensation with methyl 2-(diethoxyphosphoryl)acetate and reduction of the ester formed. The allylic alcohol 345 was converted to its epoxide before alkylation with $\mathrm{Me}_{2} \mathrm{CuCNLi}_{2}$ to give the diol 346. Oxidation of the primary alcohol followed by coupling with $\mathrm{EtO}_{2} \mathrm{C}-\mathrm{C}\left(=\mathrm{PPh}_{3}\right) \mathrm{Me}$ gave the unsaturated ester 347 which was reduced and oxidized to the aldehyde 348. Protection of the alcohol, conversion of the aldehyde to its corresponding vinyl iodide and alcohol deprotection provided the third fragment $\mathbf{3 3 0}$ for the synthesis of callystatin in $21 \%$ overall yield from 341. Coupling of 340 with 330 (the TBS protected 330) in the presence of $t$-BuLi and MeO-9-BBN to provide a boronate intermediate in order to be subjected to a palladium-catalyzed crosscoupling led to the formation of the pentaene $\mathbf{3 5 0}$ in $38 \%$ yield. Final FGIs followed by alcohol deprotection gave callystatin A (327) in 3.5\% overall yield.

\subsubsection{Corals}

A synthesis of racemic pathylactone A (352), isolated from the soft coral Paralemnalia thyrsoides,${ }^{117}$ was developed (Scheme 14) ${ }^{118}$ from 2-methylcyclohex-2-en-1-one (353) by 

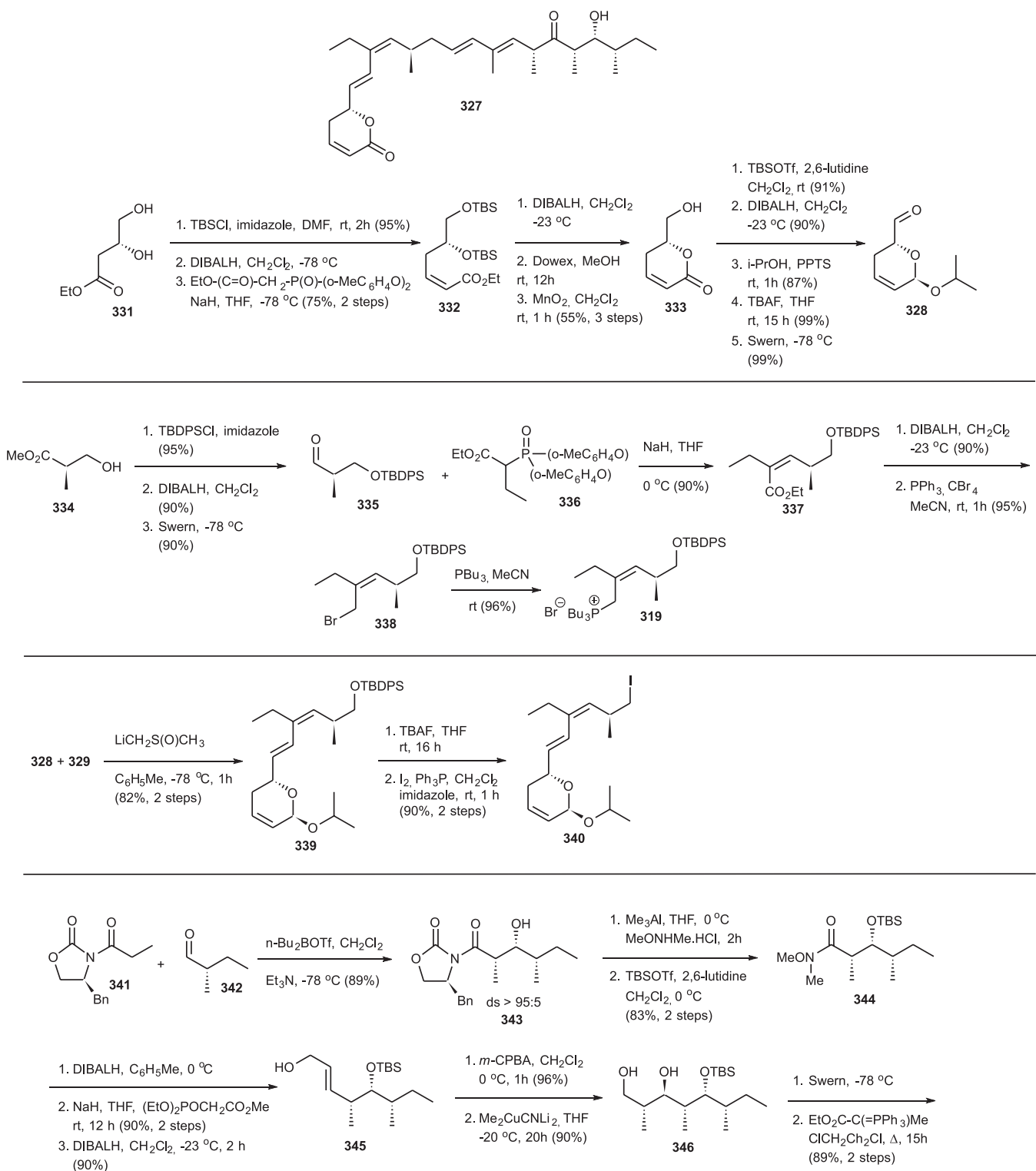

$$
(90 \%)
$$
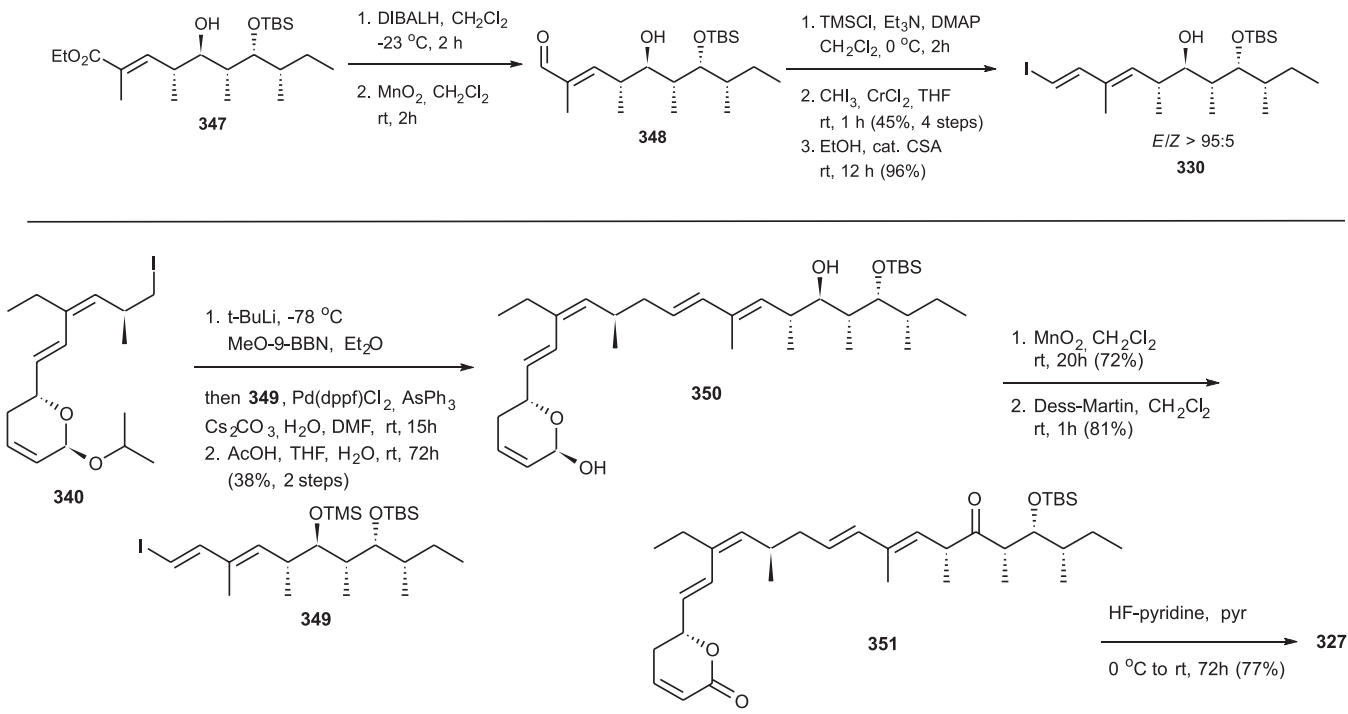

Scheme 13. Total synthesis of callystatin A (327) ${ }^{116}$ 


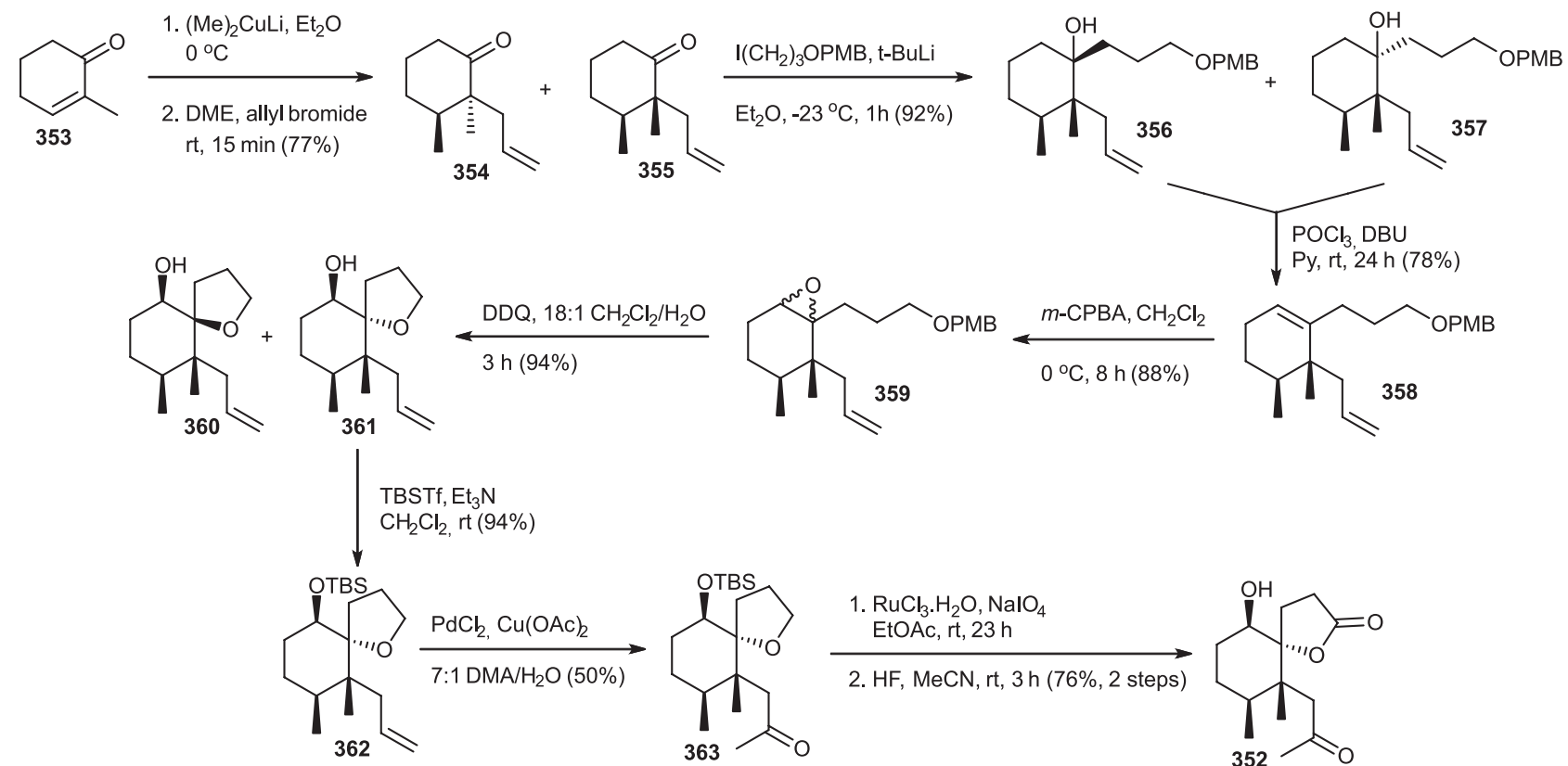

Scheme 14. Total synthesis of racemic pathylactone A (352). ${ }^{118}$

alkylation with the Gilman reagent then with allyl bromide, to give a 1:4 mixture of stereoisomers $\mathbf{3 5 4}$ and $\mathbf{3 5 5}$. Intermediate 355 was further alkylated with 1-((3-iodopropoxy)methyl)4-methoxybenzene to give the mixture of alcohols 356 and 357 which was transformed into the alkene 358 with $\mathrm{POCl}_{3}$ and DBU. Double dond epoxidation followed by cyclization provided a mixture of tetrahydrofurans 360 and 361 . Alcohol protection and double bond cleavage on the stereoisomer $\mathbf{3 6 1}$ gave the ketone 363 which was transformed into the natural product $\mathbf{3 5 2}$ after oxidation of the tetrahydrofuran ring into its respective lactone followed by alcohol deprotection. Careful analysis of the NMR data obtained by the authors for synthetic $\mathbf{3 5 2}$ indicated that the original report on its isolation presented some misassignments, particularly for the carbinolic group.

\subsubsection{Mollusks}

A synthesis of racemic spisulosine (364), previously isolated from the clam Spisula polynyma, was achieved
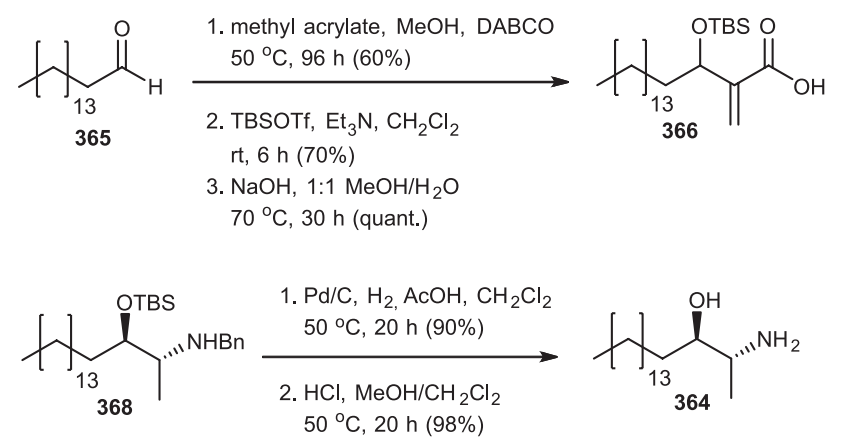

Scheme 15. Total synthesis of racemic spisulosine (364). ${ }^{119}$
(Scheme 15). ${ }^{119}$ Palmitaldehyde (365) was subjected to a Morita-Baylis-Hillman reaction with methyl acrylate and 1,4-diazabicyclo[2.2.2]octane (DABCO), to provide the corresponding alcohol-conjugated ester, which was protected and hydrolysed to give $\mathbf{3 6 6}$. The acid $\mathbf{3 6 6}$ was subjected to a Curtius rearrangement to give the acyloin $\mathbf{3 6 7}$ in $40 \%$ in a four-step reaction sequence. Condensation of 367 with benzylamine and mild reduction with $\mathrm{NaBH}_{3} \mathrm{CN}$ gave the protected amine 368 . Deprotection of both benzyl and sylil groups led to the natural product $\mathbf{3 6 4}$ in $\mathbf{1 0 \%}$ overall yield.

\subsubsection{Ascidians}

Polycitrin A (369), isolated previously from the ascidian Polycitor africanus, ${ }^{120}$ has been synthezised using a Heck arylation as the key step (Scheme 16). ${ }^{121}$ Palladiummediated Heck arylation between maleic anhydride with the tetrafluoroborate salt of diazonium $\mathbf{3 7 1}$ gave anhydride 372 in $46 \%$ yield after the deprotection of phenol groups.

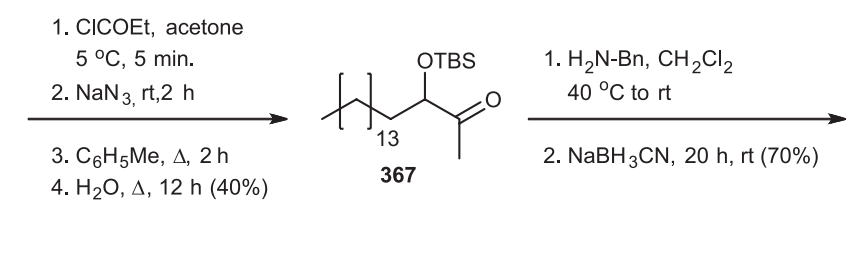



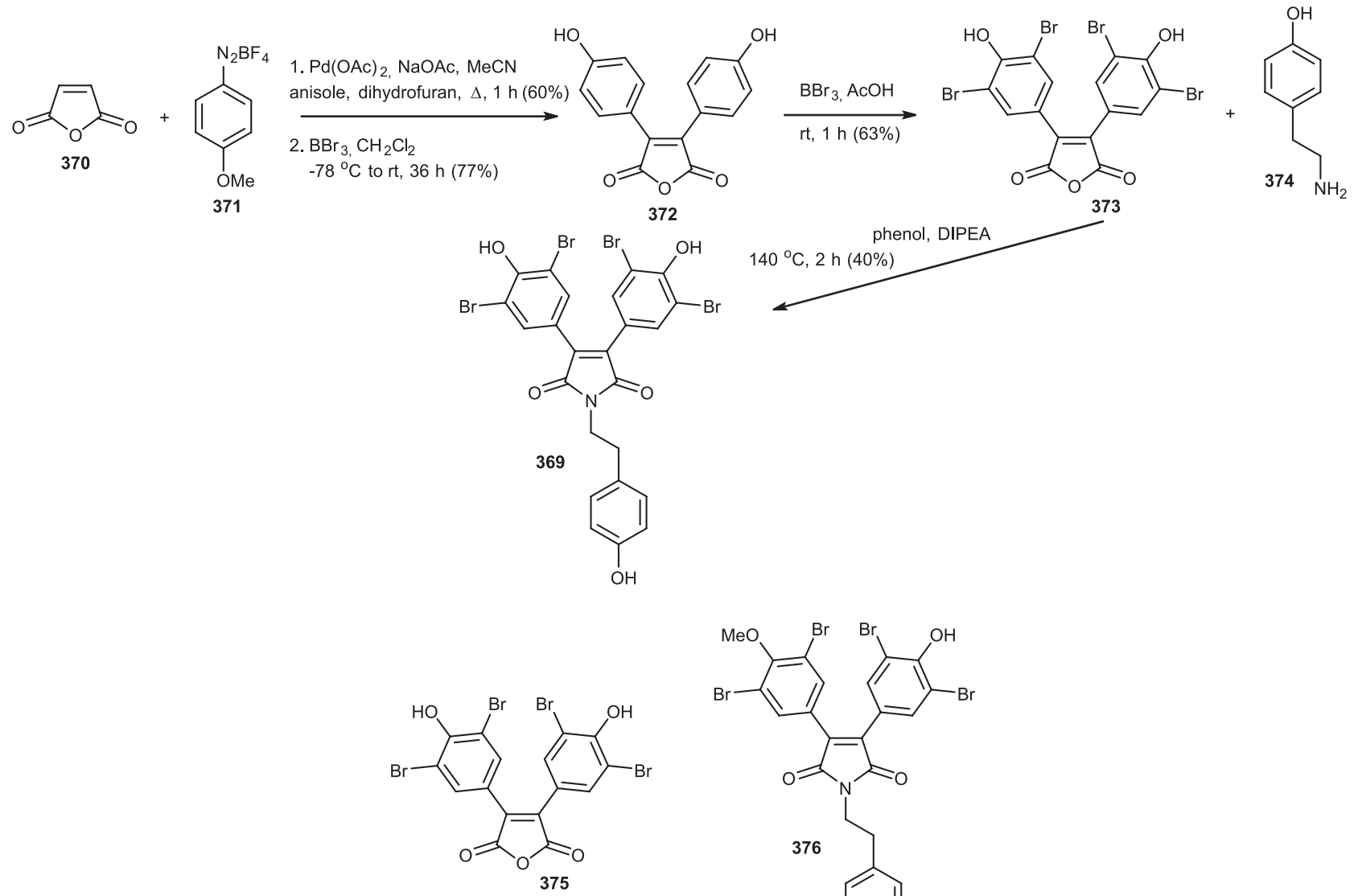<smiles>COc1c(Br)cc(C2=C(c3cc(Br)c(O)c(Br)c3)C(=O)N(CCc3ccc(O)cc3)C2=O)cc1Br</smiles>

Scheme 16. Total synthesis of polycitrin A (369). ${ }^{121}$

Bromination of $\mathbf{3 7 2}$ followed by coupling of product $\mathbf{3 7 3}$ with tyramine (374) provided the natural product 369 in $12 \%$ overall yield. A related and improved synthesis for polycitrin A (369), as well as for prepolycitrin (375) and polycitrin B (376), has been subsequently developed. ${ }^{122}$
Rubrolides are butenolides which have been first isolated from the ascidian Ritterella rubra. ${ }^{123}$ Recently a unified synthesis of rubrolides $\mathrm{B}, \mathrm{I}, \mathrm{K}$ and $\mathrm{O}$ has been developed (the synthesis of rubrolide B, 377, is illustrated in Scheme 17). ${ }^{124}$ Suzuki coupling of the lactone $\mathbf{3 7 8}$ with the<smiles>O=C1OCC(Cl)=C1Cl</smiles>
378<smiles>COc1ccc(Br)cc1</smiles>

379

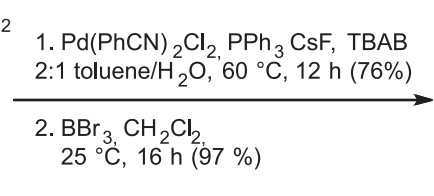

$\mathrm{BBr}_{3}, \mathrm{CH}_{2} \mathrm{Cl}_{2}$
$25^{\circ} \mathrm{C}, 16 \mathrm{~h}(97 \%$<smiles>O=C1OCC(c2ccc(O)cc2)=C1Cl</smiles>

380<smiles>COc1ccc(C=O)cc1</smiles>

381<smiles>COc1ccc(/C=C2\OC(=O)C(Cl)=C2c2ccc(O)cc2)cc1</smiles>

1. $\mathrm{BBr}_{3}, \mathrm{CH}_{2} \mathrm{Cl}_{2}$ $25^{\circ} \mathrm{C}, 16 \mathrm{~h}(94 \%)$

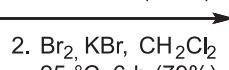<smiles>O=C1O/C(=C\c2cc(Br)c(O)c(Br)c2)C(c2cc(Br)c(O)c(Br)c2)=C1Cl</smiles>

Scheme 17. Total synthesis of synthesis of rubrolide B (377). ${ }^{124}$ 
boronic aromatic derivative $\mathbf{3 7 9}$ gave the product $\mathbf{3 8 0}$ in very good yield (73\%) after deprotection. The aromatic lactone 380 was then coupled with para-methoxybenzaldehyde (381) to afford intermediate 382. Deprotection of the phenol group followed by perbromination of both benzene moieties led to the natural product $\mathbf{3 7 7}$ in $42 \%$ overall yield from $\mathbf{3 7 8}$.

These remarkable total syntheses by Brazilian organic synthetic chemists represent major achievements, during a period of limited financial support for research by Brazilian Federal funding agencies. Sadly, the real challenge of total synthesis of natural products in Brazil is currently being pursued by only very few research groups of organic chemists, most of which are senior researchers. Therefore, we expect a diminishing number of total syntheses of marine natural products achievements by Brazilian chemists in the forthcoming years.

\section{Marine Natural Products in Brazil: Present and Future}

The current interest by Brazilian natural product scientists to investigate marine natural products is justified by the fact that secondary metabolites isolated from marine organisms present a chemical diversity which is very distinct of terrestrial plants. Such interest is evident when we consider the number of isolated compounds, both known and new, and in the number of articles published within the period covered in the present review (Figures 30 and 31). This change of perspective by Brazilian natural product scientists towards marine natural products is considered very positive. Nature is virtually an infinite source of structurally exquisite compounds, most of which are biologically active. Biological sources are very abundant in Brazil, both terrestrial and marine. New strategies and bioassays, the use of modern and sensitive tools for dereplication and prioritization, searching for minor metabolites, are approaches that should be envisaged for the discovery of new natural compounds, from any biological source.

As previously predicted, ${ }^{11}$ research on marine microbial secondary metabolites expanded significantly during the 2004-2017 period (Figure 31). This is certainly also associated to the chemical novelty of secondary metabolites produced by marine-derived strains, the relatively easy access to marine microbes when compared to marine invertebrate collections and the possibility to obtain large amounts of material for investigation by microbial culturing. Marine-derived fungi have been explored more extensively than marine-derived bacteria by Brazilian natural product chemists. It seems that fungi are more friendly to manipulate, to grow and to produce secondary metabolites of interest. This trend is in agreement with perspectives presented by Blunt and collaborators. ${ }^{125-139}$

Marine sponges continue to be the main source of marine natural products in Brazil, a trend that follows the overall interest by marine natural product chemists all around the world. ${ }^{125-139}$ Marine sponges are prolific in providing unique bioactive chemicals, many of which appear to be produced by associated microorganisms. As shown in Figure 32, alkaloids comprise the main group of marine secondary metabolites isolated by Brazilian researchers, followed by metabolites of mixed biosynthetic origin, polyketides and terpenes. Peptides are the least group of metabolites isolated, even including common diketopiperazines in this class of compounds. The distribution of metabolites of distinct biosynthetic pathways follow the usual distribution of marine natural products from the organisms of origin. Such patterns have been consistently observed over the

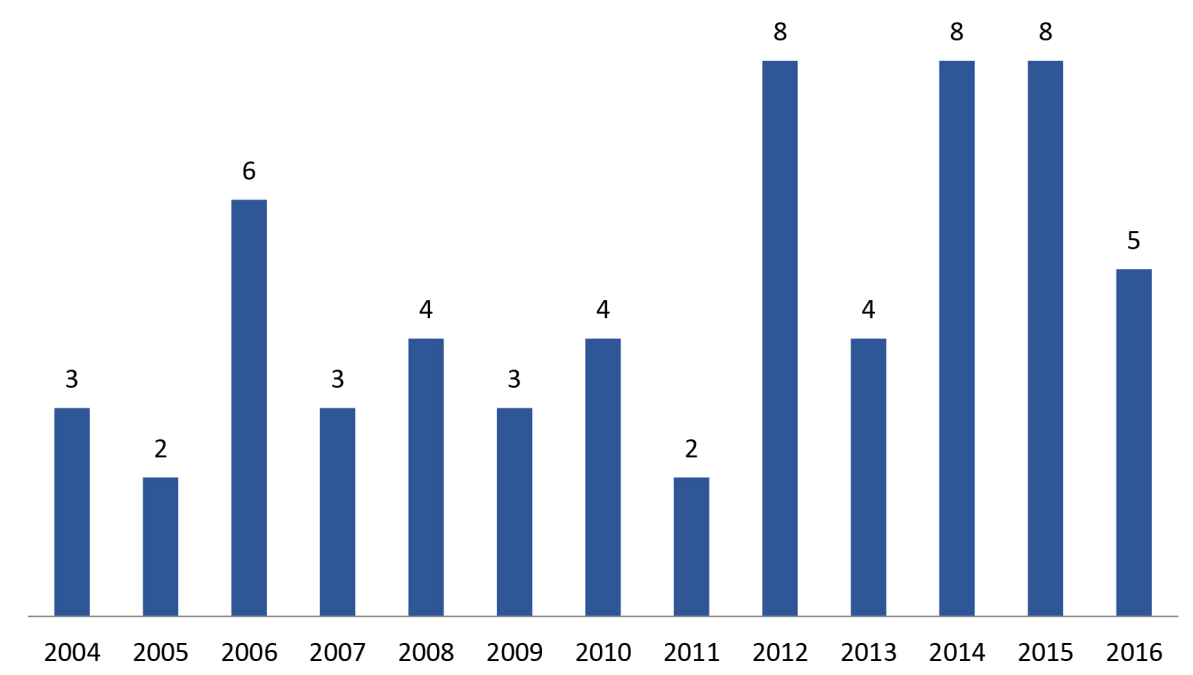

Figure 30. Articles on marine natural products published by Brazilian researchers as corresponding authors between January 2004 and August 2017. 


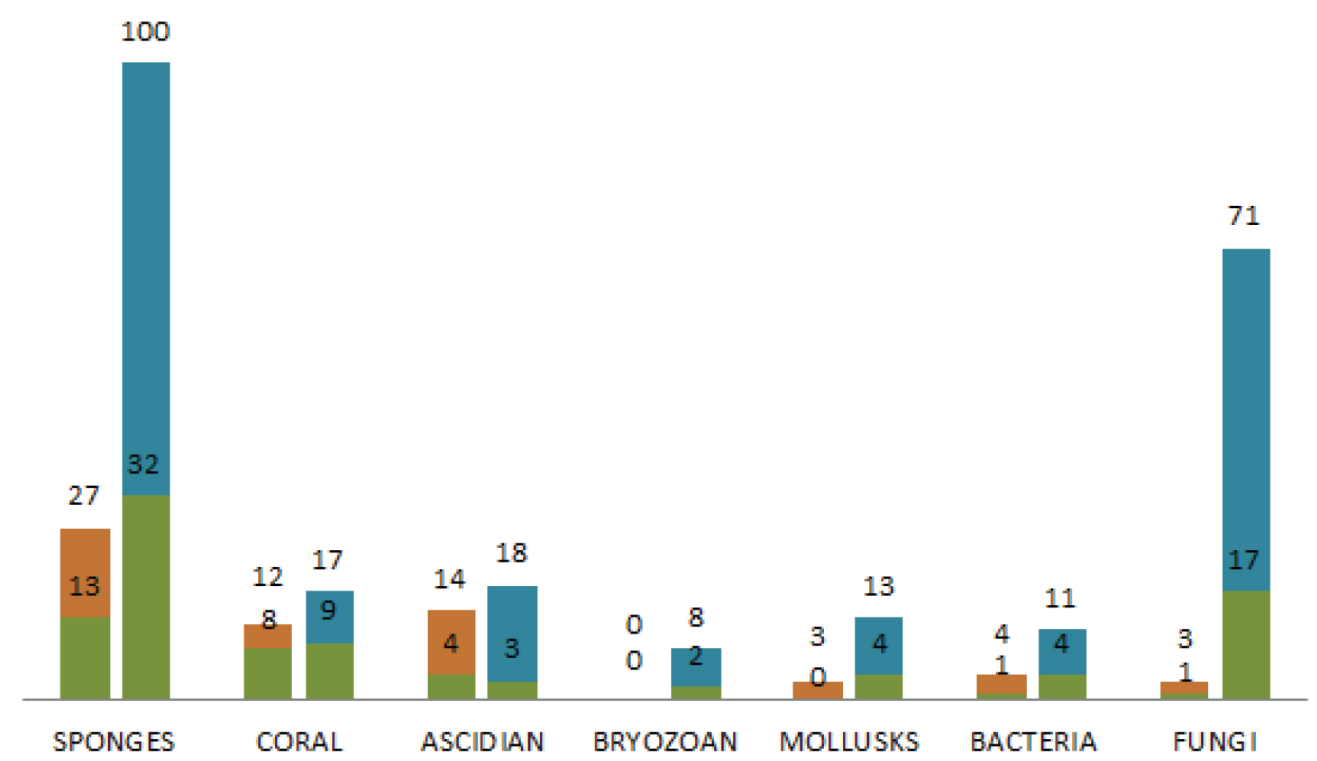

Figure 31. Number of marine natural products per biological group isolated by Brazilian researchers as corresponding authors.

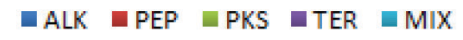

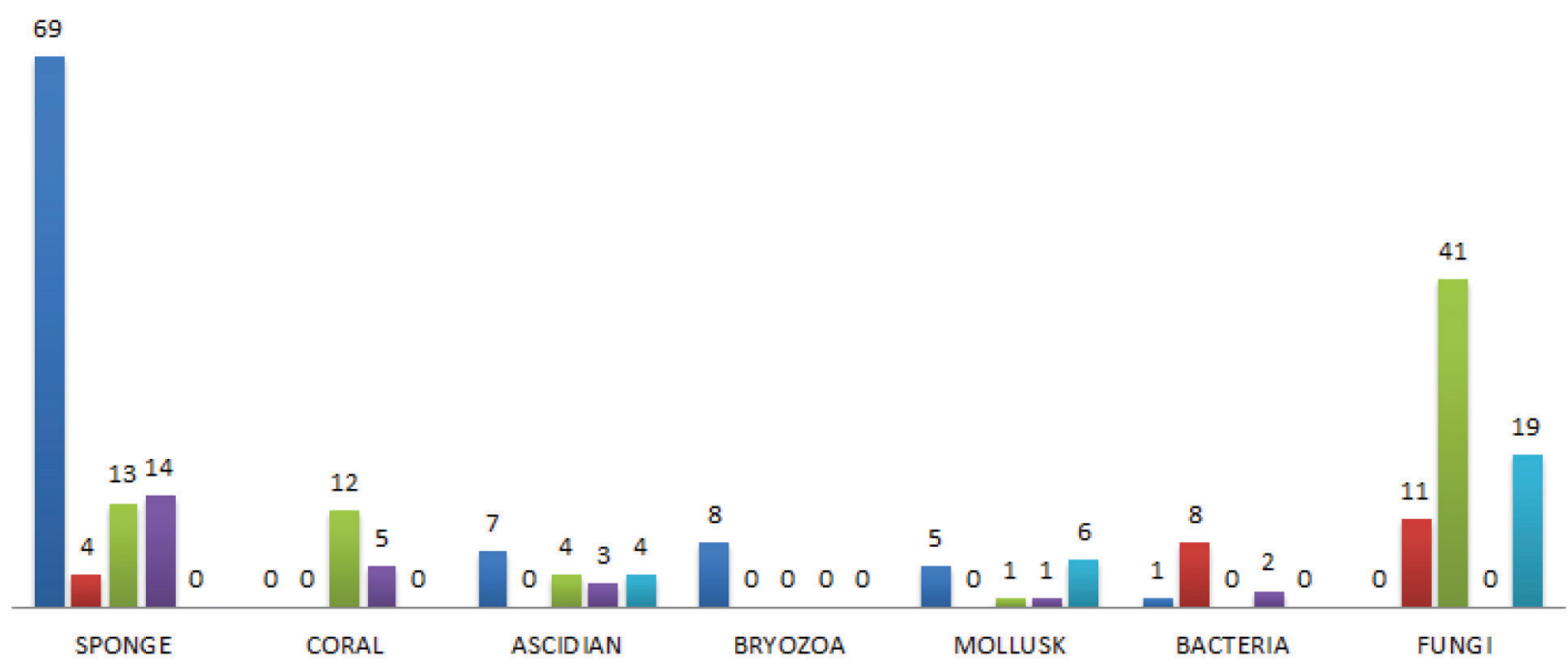

Figure 32. Biogenetic origin of marine natural products isolated by Brazilian researchers as corresponding authors.

years. ${ }^{125-139}$ Although an analysis of bioactivities has not been herein included, it sounds as illogical to correlate bioactivities to certain classes of metabolites or organisms. This is because the reported bioactivities are the author's choice rather than a comprehensive assessment of a bioactivity for each particular compound.

Perspectives for the development of marine natural products in Brazil indicate it as a promising venue.
Challenges include the access to minor and water-soluble metabolites, which are difficult to handle. Difficulties related to complex structure determination of novel minor metabolites are also evident. Additional problems to be circumvented include the re-isolation of known compounds and the chemical isolation of culture media components when dealing with marine microbes. Much expertise should be developed aiming to overcome such issues and promote a 
sounding capacity building and science of utmost quality, as marine natural products has shown to be since its origins in the 1950's. As for microbial natural products, ${ }^{1}$ the chemistry of marine natural products in Brazil is still in its infancy. It is expected to grow to its maturity in the forthcoming years, resulting from the development of multidisciplinary projects. Marine natural products chemistry in Brazil should be well developed in order to deserve its current designation-marine bioproducts from the blue Amazon.

\section{Acknowledgments}

The authors are gratefully indebted to FAPESP for financial support (BIOTA-BIOprospecTA 2013/50228-8 and a PhD scholarship to L. P. I., 2016/05133-7).

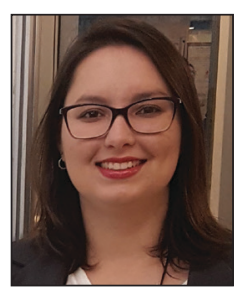

Laura P. Ióca graduated in Physical and Biomolecular Sciences at the Instituto de Física de São Carlos, Universidade de São Paulo, in 2013. In 2012, she was a visiting student at the Scripps Institution of Oceanography under the supervision of Paul R. Jensen. She got an MSc Degree and is currently a PhD student at the Instituto de Química de São Carlos, Universidade de São Paulo, under the supervision of $\mathrm{Dr}$ Roberto G. S. Berlinck. Her research interests include the investigation of metabolism and biosynthesis of secondary metabolites from microorganisms.

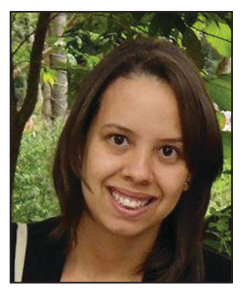

Karen J. Nicacio graduated in Chemistry at State University of Santa Cruz in 2010. In 2012 she completed an MSc (2012) and a PhD (2017) at the Instituto de Química de São Carlos, Universidade de São Paulo, under the supervision of Dr Roberto G. S. Berlinck. She is currently a research associate at $\mathrm{Dr}$ Berlinck's lab. Her research interests include the chemistry and biology of marine microbial secondary metabolites.

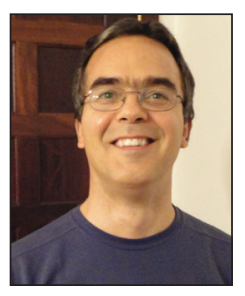

Roberto G. S. Berlinck joined the Instituto de Química de São Carlos, Universidade de São Paulo in 1993. He was appointed as associate professor in 2001 and as full professor in 2010. He was a visiting scholar at Professor Raymond J. Andersen group (University of British Columbia) and at Professor David H. Sherman group (University of Michigan). His research interests include the isolation, identification, biological activities, synthesis and biosynthesis of natural products from marine invertebrates and microorganisms.

\section{References}

1. Ióca, L. P.; Allard, P. M.; Berlinck, R. G. S.; Nat. Prod. Rep. 2014, 31, 646.

2. Li, J. Y.; Strobel, G.; Sidhu, R.; Hess, W. M.; Ford, E. J.; Microbiology 1996, 142, 2223.

3. Kumar, A.; Patil, D.; Rajamohanan, P. R.; Ahmad, A.; PLoS One 2013, 8, e71805.

4. Still, P. C.; Johnson, T. A.; Theodore, C. M.; Loveridge, S. T.; Crews, P.; J. Nat. Prod. 2014, 77, 690.

5. Bérdy, J.; J. Antibiot. 2012, 65, 385.

6. Masschelein, J.; Jenner, M.; Challis, G. L.; Nat. Prod. Rep. 2017, 34, 712 .

7. Moura, R. L.; Amado-Filho, G. M.; Moraes, F. C.; Brasileiro, P. S.; Salomon, P. S.; Mahiques, M. M.; Bastos, A. C.; Almeida, M. G.; Silva Jr., J. M.; Araujo, B. F.; Brito, F. P.; Rangel, T. P.; Oliveira, B. C. V.; Bahia, R. G.; Paranhos, R. P.; Dias, R. J. S.; Siegle, E.; Figueiredo Jr., A. G.; Pereira, R. C.; Leal, C. V.; Hajdu, E.; Asp, N. E.; Gregoracci, G. B.; Leitão, S. N.; Yager, P. L.; Francini-Filho, R. B.; Fróes, A.; Campeão, M.; Silva, B. S.; Moreira, A. P. B.; Oliveira, L.; Soares, A. C.; Araujo, L.; Oliveira, N. L.; Teixeira, J. B.; Valle, R. A. B.; Thompson, C. C.; Rezende, C. E.; Thompson, F. L.; Sci. Adv. 2016, 2, e1501252.

8. Berlinck, R. G. S.; Borges, W. S.; Scotti, M. T.; Vieira, P. V.; Quim. Nova 2017, 40, 706.

9. Soriano, E. M.; Pinto, E. P.; Yokoya, N. S.; Colepicolo, P.; Teixeira, V. L.; Valentin, Y. Y.; Braz. J. Pharmacog. 2011, 21 , available at http://www.scielo.br/scielo.php?script=sci_ arttext\&pid=S0102-695X2011000200001\&lng=en\&nrm=iso, accessed on September 13, 2017.

10. Lopes, N. P.; Rezende, C. M.; Costa-Lotufo, L. V.; Fenical, W.; Braz. J. Pharmacog. 2015, 25, 567.

11. Berlinck, R. G. S.; Hajdu, E.; Rocha, R. M.; Oliveira, J. H. H. L.; Hernández, I. L. C.; Seleghim, M. H. R.; Granato, A. C.; Almeida, E. V. R.; Nuñez, C. V.; Muricy, G.; Peixinho, S.; Pessoa, C.; Moraes, M. O.; Cavalcanti, B. C.; Nascimento, G. G. F.; Thiemann, O.; Silva, M.; Souza, A. O.; Silva, C. L.; Minarini, P. R. R.; J. Nat. Prod. 2004, 67, 510.

12. Santos, O. C. S.; Soares, A. R.; Machado, F. L. S.; Romanos, M. T. V.; Muricy, G.; Giambiagi-deMarval, M.; Laport, M. S.; Lett. Appl. Microbiol. 2015, 60, 140.

13. Ferreira, E. G.; Torres, M. C. M.; Silva, A. B.; Colares, L. L. F.; Pires, K.; Lotufo, T. M. C.; Silveira, E. R.; Pessoa, O. D. L.; Costa-Lotufo, L. V.; Jimenez, P. C.; Chem. Biodiversity 2016, 13,1149 .

14. Arthaud, I. D. B.; Rodrigues, F. A. R.; Jimenez, P. C.; Montenegro, R. C.; Angelim, A. L.; Maciel, V. M. M.; Silveira, E. R.; Freitas, H. P. S.; Sousa, T. S.; Pessoa, O. D. L.; Lotufo, 
T. M. C.; Costa-Lotufo, L. V.; Chem. Biodiversity 2012, 9, 418.

15. Miziorko, H. M.; Arch. Biochem. Biophys. 2011, 505, 131.

16. Thomasi, S. S.; Granato, A. C.; Romano, L. H.; Dhooghe, L.; Nascimento, E. S. P.; Badino, A. C.; Silva, M. F. G. F.; Ferreira, A. G.; Venâncio, T.; Nat. Prod. Commun. 2014, 9, 1275.

17. Nicacio, K. J.; Ióca, L. P.; Fróes, A. M.; Leomil, L.; Appolinario, L. R.; Thompson, C. C.; Thompson, F. L.; Ferreira, A. G.; Willians, D. E.; Andersen, R. J.; Eustaquio, A. S.; Berlinck, R. G. S.; J. Nat. Prod. 2017, 80, 235.

18. Friedrich, A. B.; Fischer, I.; Proksch, P.; Hacker, J.; Hentschel, U.; FEMS Microbiol. Ecol. 2001, 38, 105.

19. Sacristán-Soriano, O.; Banaigs, B.; Casamayor, E. O.; Becerro, M. A.; Appl. Environ. Microbiol. 2011, 77, 862.

20. Shieh, W. Y.; Lin, Y. T.; Jean, W. D.; Int. J. Syst. Evol. Microbiol. 2004, 54, 2307.

21. Schmitt, S.; Tsai, P.; Bell, J.; Fromont, J.; Ilan, M.; Lindquist, N.; Perez, T.; Rodrigo, A.; Schupp, P. J.; Vacelet, J.; Webster, N.; Hentschel, U.; Taylor, M. W.; ISME J. 2012, 6, 564.

22. Schmitt, S.; Hentschel, U.; Taylor, M. W.; Hydrobiologia 2012 , 687, 341.

23. Easson, C. G.; Thacker, R. W.; Front. Microbiol. 2014, 5, 532.

24. Weisz, J. B.; Hentschel, U.; Lindquist, N.; Martens, C. S.; Mar. Biol. 2007, 152, 475.

25. Hentschel, U.; Hopke, J.; Horn, M.; Friedrich, A. B.; Wagner, M.; Hacker, J.; Moore, B. S.; Appl. Environ. Microbiol. 2002, $68,4431$.

26. Taylor, M. W.; Radax, R.; Steger, D.; Wagner, M.; Microbiol. Mol. Biol. Rev. 2007, 71, 295.

27. Fieseler, L.; Hentschel, U.; Grozdanov, L.; Schirmer, A.; Wen, G.; Platzer, M.; Hrvatin, S.; Butzke, D.; Zimmermann, K.; Piel, J.; Appl. Environ. Microbiol. 2007, 73, 2144.

28. Siegl, A.; Hentschel, U.; Environ. Microbiol. Rep. 2010, $2,507$.

29. Webster, N. S.; Thomas, T.; mBio 2016, 7, e00135-16.

30. Hentschel, U.; Piel, J.; Degnan, S. M.; Taylor, M. W.; Nat. Rev. Microbiol. 2012, 10, 641.

31. Thacker, R. W.; Freeman, C. J.; Adv. Mar. Biol. 2012, 62, 57.

32. Esteves, A. I. S.; Amer, N.; Nguyen, M.; Thomas, T.; Front. Microbiol. 2016, 7, 499.

33. Lira, S. P.; Vita-Marques, A. M.; Seleghim, M. H. R.; Bugni, T. S.; LaBarbera, D. V.; Sette, L. D.; Sponchiado, S. R. P.; Ireland, C. M.; Berlinck, R. G. S.; J. Antibiot. 2006, 59, 553.

34. Vita-Marques, A. M.; Lira, S. P.; Berlinck, R. G. S.; Seleghim, M. H. R.; Sponchiado, S. R. P.; Tauk-Tornisielo, S. M.; Barata, M.; Pessoa, C.; Moraes, M. O.; Cavalcanti, B. C.; Nascimento, G. G. F.; Souza, A. O.; Galetti, F. C. S.; Silva, C. L.; Silva, M.; Pimenta, E. F.; Thiemann, O.; Passarini, M. R. Z.; Sette, L. D.; Quim. Nova 2008, 31, 1099.

35. Pedras, M. S. C.; Zaharia, L. I.; Ward, D. E.; Phytochemistry 2002, 59, 579.

36. Liu, B. L.; Tzeng, Y. M.; Biotechnol. Adv. 2012, 30, 1242.
37. Pimenta, E. F.; Vita-Marques, A. M.; Tininis, A.; Seleghim, M. H. R.; Sette, L. D.; Veloso, K.; Ferreira, A. G.; Williams, D. E.; Patrick, B. O.; Dalisay, D. S.; Andersen, R. J.; Berlinck, R. G. S.; J. Nat. Prod. 2010, 73, 1821.

38. Romminger, S.; Pimenta, E. F.; Nascimento, E. S.; Ferreira, A. G.; Berlinck, R. G. S.; J. Braz. Chem. Soc. 2012, 23, 1783.

39. Mercado-Marin, E. V.; Garcia-Reynaga, P.; Romminger, S.; Pimenta, E. F.; Romney, D. K.; Lodewyk, M. W.; Williams, D. E.; Andersen, R. J.; Miller, S. J.; Tantillo, D. J.; Berlinck, R. G. S.; Sarpong, R.; Nature 2014, 509, 318.

40. Newmister, S. A.; Gober, C. M.; Romminger, S.; Yu, F.; Tripathi, A.; Parra, L. L. L.; Williams, R. M.; Berlinck, R. G. S.; Joullié, M. M.; Sherman, D. H.; J. Am. Chem. Soc. 2016, 138, 11176.

41. Kossuga, M. H.; Romminger, S.; Xavier, C.; Milanetto, M. C.; Valle, M. Z.; Pimenta, E. F.; Morais, R. P.; Carvalho, E.; Mizuno, C. M.; Coradello, L. F. C.; Barroso, V. M.; Vacondio, B.; Javaroti, D. C. D.; Seleghim, M. H. R.; Cavalcanti, B. C.; Pessoa, C.; Moraes, M. O.; Lima, B. A.; Gonçalves, R.; Bonugli-Santos, R. C.; Sette, L. D.; Berlinck, R. G. S.; Braz. J. Pharmacogn. 2012, 22, 257.

42. Toledo, T. R.; Dejani, N. N.; Monnazzi, L. G. S.; Kossuga, M. H.; Berlinck, R. G. S.; Sette, L. D.; Medeiros, A. I.; Mediators Inflammation 2014, 2014, 767061.

43. Ióca, L. P.; Romminger, S.; Santos, M. F. C.; Bandeira, K. F.; Rodrigues, F. T.; Kossuga, M. H.; Nicacio, K. J.; Ferreira, E. L. F.; Morais-Urano, R. P.; Passos, M. S.; Kohn, L. K.; Arns, C. W.; Sette, L. D.; Berlinck, R. G. S.; Quim. Nova 2016, 39, 720.

44. Erbert, C.; Lopes, A. A.; Yokoya, N. S.; Furtado, N. A. J. C.; Conti, R.; Pupo, M. T.; Lopes, J. L. C.; Debonsi, H. M.; Bot. Mar. 2012, 55, 435.

45. Montenegro, T. G. C.; Rodrigues, F. A. R.; Jimenez, P. C.; Angelim, A. L.; Melo, V. M. M.; Rodrigues-Filho, E.; Oliveira, M. C. F.; Costa-Lotufo, L. V.; Chem. Biodivers. 2012, 9, 2203.

46. Kossuga, M. H.; Ferreira, A. G.; Sette, L. D.; Berlinck, R. G. S.; Nat. Prod. Commun. 2013, 8, 721.

47. Saraiva, N. N.; Rodrigues, B. S. F.; Jimenez, P. C.; Guimarães, L. A.; Torres, M. C. M.; Rodrigues-Filho, E.; Pfenning, L. H.; Abreu, L. M.; Mafezoli, J.; Mattos, M. C.; Costa-Lotufo, L. V.; Oliveira, M. C. F.; Nat. Prod. Res. 2014, 29, 1545.

48. Felício, R.; Pavão, G. B.; Oliveira, A. L. L.; Erbert, C.; Conti, R.; Pupo, M. T.; Furtado, N. A. J. C.; Ferreira, E. G.; Costa-Lotufo, L. V.; Young, M. C. M.; Yokoya, N. S.; Debonsi, H. M.; Braz. J. Pharmacog. 2015, 25, 641.

49. Ferreira, E. L. F.; Williams, D. E.; Ióca, L. P.; Morais-Urano, R. P.; Santos, M. F. C.; Patrick, B. O.; Elias, L. M.; Lira, S. P.; Ferreira, A. G.; Passarini, M. R. Z.; Sette, L. D.; Andersen, R. J.; Berlinck, R. G. S.; Org. Lett. 2015, 17, 5152.

50. Castro, M. V.; Ióca, L. P.; Williams, D. E.; Costa, B. Z.; Mizuno, C. M.; Santos, M. F. C.; Jesus, K.; Ferreira, E. L. F.; Seleghim, M. H. R.; Sette, L. D.; Pereira-Filho, E. R.; Ferreira, A. G.; 
Gonçalves, N. S.; Santos, R. A.; Patrick, B. O.; Andersen, R. J.; Berlinck, R. G. S.; J. Nat. Prod. 2016, 79, 1668.

51. Oliveira, J. H. H. L.; Grube, A.; Köck, M.; Berlinck, R. G. S.; Macedo, M. L.; Ferreira, A. G.; Hajdu, E.; J. Nat. Prod. 2004, 67, 1685.

52. Cavalcanti, B. C.; Sombra, C. M. L.; Oliveira, J. H. H. L.; Berlinck, R. G. S.; Moraes, M. O.; Pessoa, C.; Comp. Biochem. Physiol. 2008, 147, 409.

53. Oliveira, J. H. H. L.; Seleghim, M. H. R.; Timm, C.; Grube, A.; Köck, M.; Nascimento, G. G. F.; Martins, A. C. T.; Silva, E. G. O.; Souza, A. O.; Minarini, P. R. R.; Galetti, F. C. S.; Silva, C. L.; Hajdu, E.; Berlinck, R. G. S.; Mar. Drugs 2006, 4,1 .

54. Oliveira, J. H. H. L.; Nascimento, A. M.; Kossuga, M. H.; Cavalcanti, B. C.; Pessoa, C. O.; Moraes, M. O.; Macedo, M. L.; Ferreira, A. G.; Hajdu, E.; Pinheiro, U. S.; Berlinck, R. G. S.; J. Nat. Prod. 2007, 70, 538.

55. Souza, T. M. L.; Abrantes, J. L.; Epifanio, R. A.; Fontes, C. F. L.; Frugulhetti, I. C. P. P.; Planta Med. 2007, 73, 200.

56. Molinski, T. F.; Biegelmeyer, R.; Stout, E. P.; Wang, X.; Frota Jr., M. L. C.; Henriques, A. T.; J. Nat. Prod. 2013, 76, 374.

57. Arevabini, C.; Crivelenti, Y. D.; Abreu, M. H.; Bitencourt, T. A.; Santos, M. F. C.; Berlinck, R. G. S.; Hajdu, E.; Beleboni, R. O.; Fachin, A. L.; Marins, M.; Nat. Prod. Commun. 2014, 9,33 .

58. Granato, A. C.; Oliveira, J. H. H. L.; Seleghim, M. H. R.; Berlinck, R. G. S.; Macedo, M. L.; Ferreira, A. G.; Rocha, R. M.; Hajdu, E.; Peixinho, S.; Pessoa, C. O.; Moraes, M. O.; Cavalcanti, B. C.; Quim. Nova 2005, 28, 192.

59. Rangel, M.; Prado, M. P.; Konno, K.; Naoki, H.; Freitas, J. C.; Machado-Santelli, G. M.; Peptides 2006, 27, 2047.

60. Rangel, M.; Ionta, M.; Pfister, S. C.; Ferreira, R. A. S.; MachadoSantelli, G. M.; Cell Biol. Int. Rep. 2010, 17, 13.

61. Berlinck, R. G. S.; Romminger, S.; Nat. Prod. Rep. 2016, 33, 456.

62. Berlinck, R. G. S.; Trindade-Silva, A. E.; Santos, M. F. C.; Nat. Prod. Rep. 2012, 29, 1382.

63. Berlinck, R. G. S.; Burtoloso, A. C. B.; Trindade-Silva, A. E.; Romminger, S.; Morais, R. P.; Bandeira, K.; Mizuno, C. M.; Nat. Prod. Rep. 2010, 27, 1871.

64. Berlinck, R. G. S.; Burtoloso, A. C. B.; Kossuga, M. H.; Nat. Prod. Rep. 2008, 25, 919.

65. Berlinck, R. G. S.; Kossuga, M. H.; Nat. Prod. Rep. 2005, 22, 516.

66. Berlinck, R. G. S.; Nat. Prod. Rep. 2002, 19, 617.

67. Berlinck, R. G. S.; Nat. Prod. Rep. 1999, 16, 339.

68. Berlinck, R. G. S.; Nat. Prod. Rep. 1996, 13, 377.

69. Kossuga, M. H.; Lira, S. P.; Nascimento, A. M.; Gambardella, M. T. P.; Berlinck, R. G. S.; Torres, Y. R.; Nascimento, G. G. F.; Pimenta, E. F.; Silva, M.; Thiemann, O. H.; Oliva, G.; Tempone, A. G.; Melhem, M. S. C.; Souza, A. O.; Galetti, F. C. S.; Silva,
C. L.; Cavalcanti, B.; Pessoa, C. O.; Moraes, M. O.; Hajdu, E.; Peixinho, S.; Rocha, R. M.; Quim. Nova 2007, 30, 1194.

70. Ferreira, E. G.; Wilke, D. V.; Jimenez, P. C.; Oliveira, J. R.; Pessoa, O. D. L.; Silveira, E. R.; Viana, F. A.; Pessoa, C.; Moraes, M. O.; Hajdu, E.; Costa-Lotufo, L. V.; Chem. Biodivers. 2011, 8, 1433.

71. Santos, M. F. C.; Harper, P. M.; Williams, D. E.; Mesquita, J. T.; Pinto, E. G.; Costa-Silva, T. A.; Hajdu, E.; Ferreira, A. G.; Santos, R. A.; Murphy, P. J.; Andersen, R. J.; Tempone, A. G.; Berlinck, R. G. S.; J. Nat. Prod. 2015, 78, 1101.

72. Nuñez, C. V.; Almeida, E. V. R.; Granato, A. C.; Marques, S. O.; Santos, K. O.; Pereira, F. R.; Macedo, M. L.; Ferreira, A. G.; Hajdu, E.; Pinheiro, U. S.; Muricy, G.; Peixinho, S.; Freeman, C. J.; Gleason, D. F.; Berlinck, R. G. S.; Biochem. Syst. Ecol. 2008, 36, 283.

73. Oliveira, M. F.; Oliveira, J. H. H. L.; Galetti, F. C. S.; Souza, A. O.; Silva, C. L.; Hadju, E.; Peixinho, S.; Berlinck, R. G. S.; Planta Med. 2006, 72, 437.

74. Lira, T. O.; Berlinck, R. G. S.; Nascimento, G. G. F.; Hajdu, E.; J. Braz. Chem. Soc. 2006, 17, 1233.

75. Gandolfi, R. C.; Medina, M. B.; Berlinck, R. G. S.; Lira, S. P.; Galetti, F. C. S.; Silva, C. L.; Veloso, K.; Ferreira, A. G.; Hajdu, E.; Peixinho, S.; Quim. Nova 2010, 33, 1853.

76. Medeiros, A. I.; Gandolfi, R. C.; Secatto, A.; Falcucci, R. M.; Faccioli, L. H.; Hajdu, E.; Peixinho, S.; Berlinck, R. G. S.; Immunopharmacol. Immunotoxicol. 2012, 34, 919.

77. Silva, M. M.; Bergamasco, J.; Lira, S. P.; Lopes, N. P.; Hajdu, E.; Peixinho, S.; Berlinck, R. G. S.; Aust. J. Chem. 2010, 63, 886.

78. Lira, N. S.; Monte-Neto, R. L.; Marchi, J. G. B.; Lins, A. C. S.; Tavares, J. F.; Silva, M. S.; Dias, C. S.; Barbosa-Filho, J. M.; Santos, C. F.; Cunha, E. V. L.; Pinheiro, U. S.; Braz-Filho, R.; Quim. Nova 2012, 35, 2189

79. Guimarães, T. R.; Quiroz, C. G.; Rigotto, C.; Oliveira, S. Q.; Almeida, M. T. R.; Bianco, E. M.; Moritz, M. I. G.; Carraro, J. L.; Palermo, J. A.; Cabrera, G.; Schenkel, E. P.; Reginatto, F. H.; Simões, C. M. O.; Mar. Drugs 2013, 11, 4176.

80. Williams, D. E.; Marques, S. O.; Hajdu, E.; Peixinho, S.; Andersen, R. J.; Berlinck, R. G. S.; J. Nat. Prod. 2009, 72, 1691.

81. Gray, C. A.; Lira, S. P.; Silva, M.; Pimenta, E. F.; Thiemann, O. H.; Oliva, G.; Hajdu, E.; Andersen, R. J.; Berlinck, R. G. S.; J. Org. Chem. 2006, 71, 8685.

82. Kossuga, M. H.; Nascimento, A. M.; Reimão, J. Q.; Tempone, A. G.; Taniwaki, N. N.; Veloso, K.; Ferreira, A. G.; Cavalcanti, B. C.; Pessoa, C.; Moraes, M. O.; Mayer, A. M. S.; Hajdu, E.; Berlinck, R. G. S.; J. Nat. Prod. 2008, 71, 334.

83. Santos, E. A.; Quintela, A. L.; Ferreira, E. G.; Sousa, T. S.; Pinto, F. C. L.; Hajdu, E.; Carvalho, M. S.; Salani, S.; Rocha, D. D.; Wilke, D. V.; Torres, M. C. M.; Jimenez, P. C.; Silveira, E. R.; Clair, J. J.; Pessoa, O. D. L.; Costa-Lotufo, L. V.; J. Nat. Prod. 2015, 78, 996. 
84. Ramirez, M. C. A.; Williams, D. E.; Gubiani, J. R.; Parra, L. L. L.; Santos, M. F. C.; Ferreira, D. D.; Mesquita, J. T.; Tempone, A. G.; Ferreira, A. G.; Padula, V.; Hajdu, E.; Andersen, R. J.; Berlinck, R. G. S.; J. Nat. Prod. 2017, 80, 720.

85. Fleury, B. G.; Lages, B. G.; Barbosa, J. P.; Kaiser, C. R.; Pinto, A. C.; J. Chem. Ecol. 2008, 34, 987.

86. Moritz, M. I. G.; Marostica, L. L.; Bianco, E. M.; Almeida, M. T. R.; Carraro, J. L.; Cabrera, G. M.; Palermo, J. A.; Simões, C. M. O.; Schenkel, E. P.; Mar. Drugs 2014, 12, 5864.

87. Abreu, P. A.; Wilke, D. V.; Araujo, A. J.; Marinho-Filho, J. D. B.; Ferreira, E. G.; Ribeiro, C. M. R.; Pinheiro, L. S.; Amorim, J. W.; Valverde, A. L.; Epifanio, R. A.; Costa-Lotufo, L. V.; Jimenez, P. C.; Braz. J. Pharmacog. 2015, 25, 634.

88. Sousa, T. S.; Nuzzo, G.; Torres, M. C. M.; Lopes, N. P.; Cutignano, A.; Jimenez, P. C.; Santos, E. A.; Gomes, B. A.; Sardo, A.; Pessoa, O. D. L.; Costa-Lotufo, L. V.; Fontana, A.; Braz. J. Pharmacog. 2015, 25, 600.

89. Pereira, F. R.; Berlinck, R. G. S.; Rodrigues-Filho, E.; Veloso, K.; Ferreira, A. G.; Padula, V.; Quim. Nova 2012, 35, 2194.

90. Santos, L. A. H.; Clavico, E. E. G.; Parra, L. L. L.; Berlinck, R. G. S.; Ferreira, A. G.; Paul, V. J.; Pereira, R. C.; J. Braz. Chem. Soc. 2017, 28, 435.

91. Pereira, F. R.; Santos, M. F. C.; Williams, D. E.; Andersen, R. J.; Padula, V.; Ferreira, A. G.; Berlinck, R. G. S.; J. Braz. Chem. Soc. 2014, 25, 788.

92. Schmidt, E. W.; Sudek, S.; Haygood, M. G.; J. Nat. Prod. 2004, 67, 1341.

93. Schmidt, E. W.; Donia, M. S.; McIntosh, J. A.; Fricke, W. F.; Ravel, J.; J. Nat. Prod. 2012, 75, 295.

94. Kossuga, M. H.; MacMillan, J. B.; Rogers, E. W.; Molinski, T. F.; Nascimento, G. G. F.; Rocha, R. M.; Berlinck, R. G. S.; J. Nat. Prod. 2004, 67, 1879.

95. Kossuga, M. H.; Lira, S. P.; McHugh, S.; Torres, Y. R.; Lima, B. A.; Gonçalves, R.; Veloso, K.; Ferreira, A. G.; Rocha, R. M.; Berlinck, R. G. S.; J. Braz. Chem. Soc. 2009, $20,704$.

96. Jimenez, P. C.; Wilke, D. V.; Ferreira, E. G.; Takeara, R.; Moraes, M. O.; Silveira, E. R.; Lotufo, T. M. C.; Lopes, N. P.; CostaLotufo, L. V.; Mar. Drugs 2012, 10, 1092.

97. Andréo, M. A.; Jimenez, P. C.; Siebra, J. B. C. N.; Costa-Lotufo, L. V.; Vessecchi, R.; Niehues, M.; Lopes, J. L. C.; Lopes, N. P.; J. Braz. Chem. Soc. 2012, 23, 335.

98. Kelecom, A.; J. Braz. Chem. Soc. 1998, 9, 101.

99. Burkholder, P. R.; Pfister, R. M.; Leitz, F. H.; Appl. Microbiol. 1966, 14, 649 .

100. Andersen, R. J.; Wolfe, M. S.; Faulkner, D. J.; Mar. Biol. 1974, 27, 281.

101. Schwalm, C. S.; Castro, I. B. D.; Ferrari, J.; Oliveira, F. L.; Aparicio, R.; Correia, C. R. D.; Tetrahedron Lett. 2012, 53, 1660.

102. Felder, S.; Kehraus, S.; Neu, E.; Bierbaum, G.; Schäberle, T. F.; König, G. M.; ChemBioChem 2013, 14, 1363.
103. Muddala, R.; Acosta, J. A. M.; Barbosa, L. C. A.; Boukouvalas, J.; J. Nat. Prod. 2017, 80, 2166.

104. Carneiro, V. M. T.; Avila, C. M.; Balunas, M. J.; Gerwick, W. H.; Pilli, R. A.; J. Org. Chem. 2014, 79, 630.

105. Balunas, M. J.; Grosso, M. F.; Villa, F. A.; Engene, N.; McPhail, K. L.; Tidgewell, K.; Pineda, L. M.; Gerwick, L.; Spadafora, C.; Kyle, D. E.; Gerwick, W. H.; Org. Lett. 2012, 14, 3878.

106. Pirovani, R. V.; Brito, G. A.; Barcelos, R. C.; Pilli, R. A.; Mar. Drugs 2015, 13, 3309.

107. Choi, H.; Mevers, E.; Byrum, T.; Valeriote, F. A.; Gerwick, W. H.; Eur. J. Org. Chem. 2012, 5141.

108. D’Ambrosio, M.; Guerriero, A.; Pietra, F.; Helv. Chim. Acta 1984, 67, 1484; Guerriero, A.; D’Ambrosio, M.; Traldi, P.; Pietra, F.; Naturwissenschaften 1984, 71, 425.

109. Godoy, L. A. F.; Pilli, R. A.; Quim. Nova 2010, 33, 2042.

110. Capon, R. J.; Macleod, J. K.; Scammells, P. J.; Tetrahedron. 1986, 42, 6545.

111. Tébéka, I. R. M.; Longato, G. B.; Craveiro, M. V.; Carvalho, J. E.; Ruiz, A. L. T. G.; Silva Jr., L. F.; Chem.-Eur. J. 2012, 18, 16890.

112. Ishibashi, M.; Ohizumi, Y.; Cheng, J. F.; Nakamura, H.; Hirata, Y.; Sasaki, T.; Kobayashi, J.; J. Org. Chem. 1989, 53, 2855.

113. Almeida, W. P.; Correia, C. R. D.; Tetrahedron Lett. 1994, 35, 1367; Almeida, W. P.; Correia, C. R. D.; J. Braz. Chem. Soc. 1999, 10, 401.

114. Lira, S. P.; Seleghim, M. H. R.; Williams, D. E.; Marion, F.; Hamill, P.; Jean, F.; Andersen, R. J.; Hajdu, E.; Berlinck, R. G. S.; J. Braz. Chem. Soc. 2007, 18, 440.

115. Kobayashi, M.; Higuchi, K.; Murakami, N.; Tajima, H.; Aoki, S.; Tetrahedron Lett. 1997, 38, 2859.

116. Dias, L. C.; Meira, P. R. R.; J. Org. Chem. 2005, 70, 4762.

117. Su, J. Y.; Zhong, Y. L.; Zeng, L. M.; J. Nat. Prod. 1993, 56, 288.

118. Coelho, F.; Diaz, G.; Tetrahedron 2002, 58, 1647.

119. Amarante, G. W.; Cavallaro, M.; Coelho, F.; Tetrahedron Lett. 2010, 51, 2597.

120. Rudi, A.; Golberg, I.; Stein, Z.; Frolow, F.; Benayahu, Y.; Schleyer, M.; Kashman, Y.; J. Org. Chem. 1994, 59, 999.

121. Burtoloso, A. C. B.; Garcia, A. L. L.; Miranda, K. C.; Correia, C. R. D.; Synlett 2006, 3145.

122. Canto, K.; Ribeiro, R. S.; Biajoli, A. F. P.; Correia, C. R. D.; Eur. J. Org. Chem. 2013, 8004.

123. Miao, S.; Andersen, R. A.; J. Org. Chem. 1991, 56, 6275.

124. Karak, M.; Acosta, J. A. M.; Barbosa, L. C. A.; Boukouvalas, J.; Eur. J. Org. Chem. 2016, 3780.

125. Blunt, J. W.; Copp, B. R.; Munro, M. H. G.; Northcote, P. T.; Prinsep, M. R.; Nat. Prod. Rep. 2003, $20,1$.

126. Blunt, J. W.; Copp, B. R.; Munro, M. H. G.; Northcote, P. T.; Prinsep, M. R.; Nat. Prod. Rep. 2004, $21,1$.

127. Blunt, J. W.; Copp, B. R.; Munro, M. H. G.; Northcote, P. T.; Prinsep, M. R.; Nat. Prod. Rep. 2005, 22, 15. 
128. Blunt, J. W.; Copp, B. R.; Munro, M. H. G.; Northcote, P. T.; Prinsep, M. R.; Nat. Prod. Rep. 2006, 23, 26.

129. Blunt, J. W.; Copp, B. R.; Hu, W. P.; Munro, M. H. G.; Northcote, P. T.; Prinsep, M. R.; Nat. Prod. Rep. 2007, 24, 31.

130. Blunt, J. W.; Copp, B. R.; Hu, W. P.; Munro, M. H. G.; Northcote, P. T.; Prinsep, M. R.; Nat. Prod. Rep. 2008, 25, 35.

131. Blunt, J. W.; Copp, B. R.; Hu, W. P.; Munro, M. H. G.; Northcote, P. T.; Prinsep, M. R.; Nat. Prod. Rep. 2009, 26, 170.

132. Blunt, J. W.; Copp, B. R.; Munro, M. H. G.; Northcote, P. T.; Prinsep, M. R.; Nat. Prod. Rep. 2010, 27, 165.

133. Blunt, J. W.; Copp, B. R.; Munro, M. H. G.; Northcote, P. T.; Prinsep, M. R.; Nat. Prod. Rep. 2011, 28, 196.

134. Blunt, J. W.; Copp, B. R.; Keyzers, R. A.; Munro, M. H. G.; Prinsep, M. R.; Nat. Prod. Rep. 2012, 29, 144.
135. Blunt, J. W.; Copp, B. R.; Keyzers, R. A.; Munro, M. H. G.; Prinsep, M. R.; Nat. Prod. Rep. 2013, 30, 237.

136. Blunt, J. W.; Copp, B. R.; Keyzers, R. A.; Munro, M. H. G.; Prinsep, M. R.; Nat. Prod. Rep. 2014, 31, 160.

137. Blunt, J. W.; Copp, B. R.; Keyzers, R. A.; Munro, M. H. G.; Prinsep, M. R.; Nat. Prod. Rep. 2015, 32, 116.

138. Blunt, J. W.; Copp, B. R.; Keyzers, R. A.; Munro, M. H. G.; Prinsep, M. R.; Nat. Prod. Rep. 2016, 33, 382.

139. Blunt, J. W.; Copp, B. R.; Keyzers, R. A.; Munro, M. H. G.; Prinsep, M. R.; Nat. Prod. Rep. 2017, 34, 235.

Submitted: October 24, 2017

Published online: February 5, 2018 